Historic, Archive Document

Do not assume content reflects current scientific knowledge, policies, or practices. 



\section{Satterthwaite's 18\1 Catalogue}

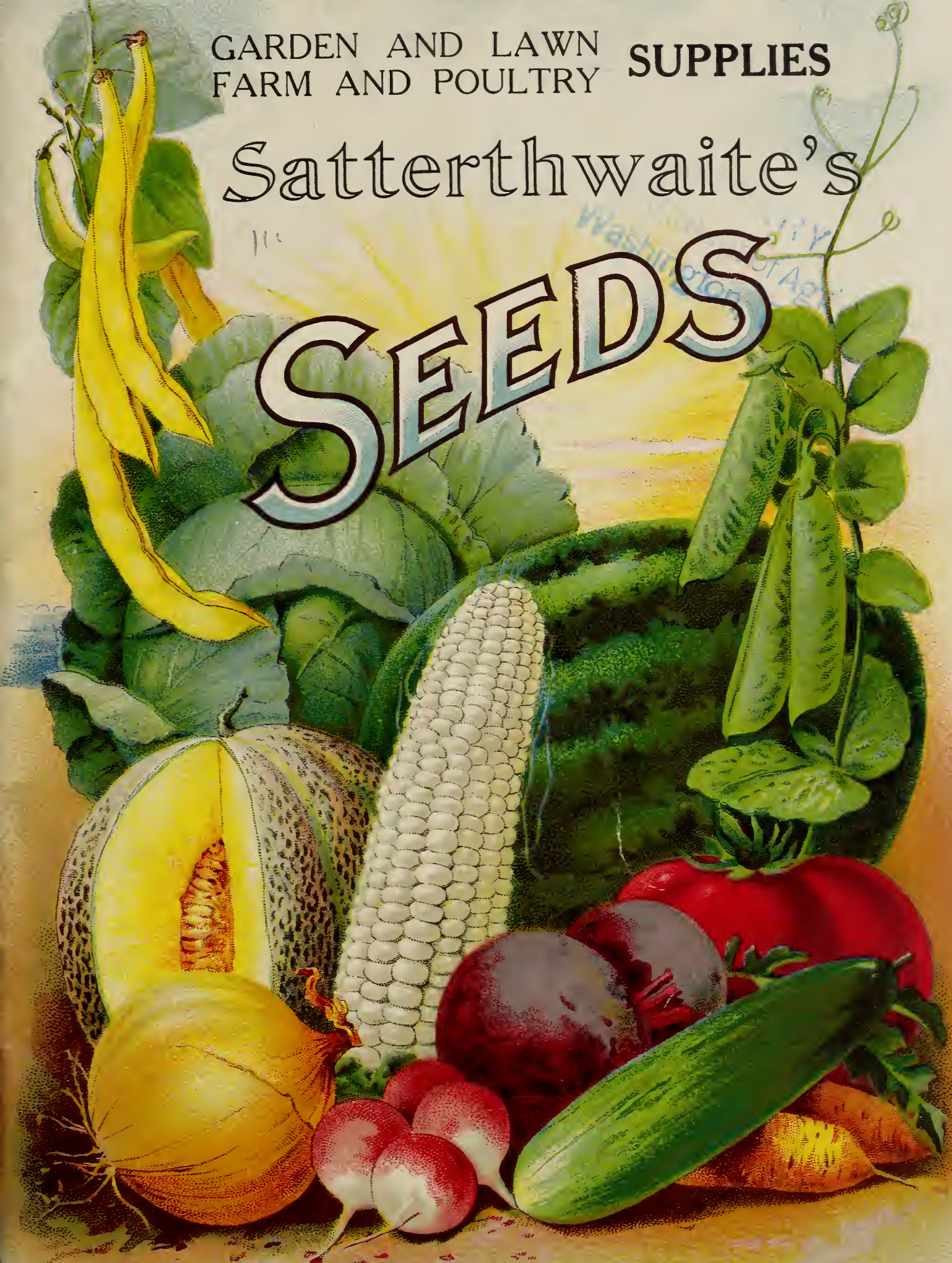

Inter-State Phone F042-B

Bell Phone 822-A

16 N. Warren St., Trenton, N. J. 


\section{The Oldest Seed House in Trenton}

\section{To My Customers}

My list of varieties is very extensive. I have tried to increase it especially this year in desire to meet the every want in the line of Vegetable, Field and Flower Seeds.

While I have not personally tested all the seed I sell, I buy only from reliable growers who have unlimited means by which the seed you buy of me is tested.

It is vitally important to every purchaser of seeds, either in large or small quantities, to know if the seeds will grow strongly and well, and whether they are pure and will produce true and perfect types of their kind. No experienced or practical gardener ever asks, "Where can I get my seeds the cheapest?" but rather "Where can I get the best and most reliable?" and no one ean afford to look at this matter in any other light.

In conclusion, I wish to say that my seeds are the very best which untiring watehfulness and intelligent, painstaking care can produce, while my prices are as low as goods ean be bought for, and I respectfully ask that you give them a trial.

1 solicit your trade, offering you the hest tested seed obtainable. Yours respectfully,

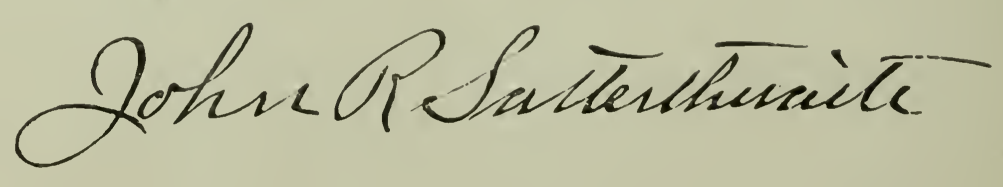




\section{INDEX.}

Choice Garden and Field Seeds ......................... 2-23

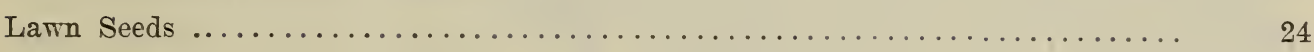

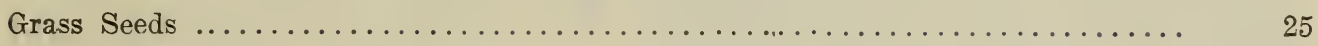

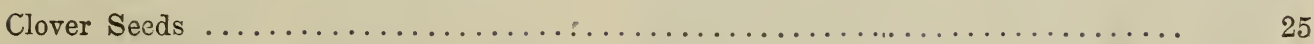

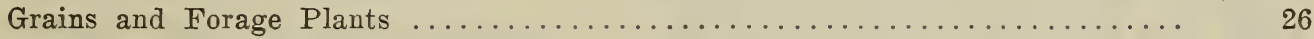

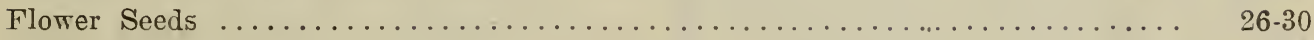

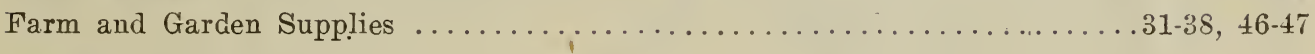

Hardware and Paints ................................. 39-44

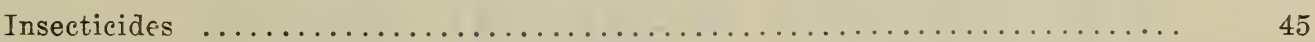

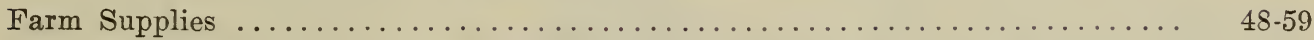

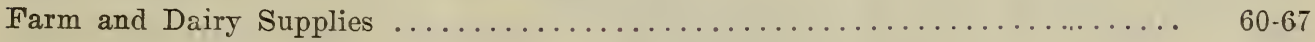

Poultry Supplies ................................. $68-71$

\section{N O T I C E}

We do not guarantee the prices in this catalogue. The prices in this book are subject to change without notices 


\section{Satterthwaite's}

\section{Tested Vegetable Seeds}

MARKET GARDENERS, or other large planters, requiring larger quantities of seeds than are here offered are invited to write for Special Prices, and must be sure to name varieties and quantities they will want.

\section{SEEDS BY MAIL.}

Please bear in mind that the prices given in this book do not include cost of postage, but packets and ounces will be sent to any address postpaid at prices named. For Peas, Beans and Corn add 8 cents per pint, 16 cents per quart, to cover postage. Quantities of $4 \mathrm{lbs}$ and over will often go cheaper by express than by mail, and if purchasers desire such quantities forwarded by express they may omit the amount required for postage.

\section{WE DO NOT WARRANT SEEDS.}

The fact that no reputable seedsman now warrants seeds in any respect being well known renders it unnecessary for us to say very much on this point, as it must be apparent to every intelligent person that no seedsman can afford to send out poor or worthless seeds, as there could be no more certain way of destroying his business. We beg to append the following notice:

While we exercise the greatest care to have all seeds pure and reliable, we do not give any warranty, express or implied. If the purchaser does not accept the goods on these terms and conditions, they must be returned at once, and the money that has been paid for same will be refunded.

\section{CHOICE GARDEN and FIELD SEEDS.}

\section{ARTICHCIK \\ Artischocke. Articioccel. Karczocky. \\ One ounce will produce 500 plants. \\ Culture.-Sow in light, rich, and rather moist soil, in drills 8 or 10 inches apart; when the plants are well up, transplant, 4 or 5 inches deep, in rows 4 feet apart and 2 feet apart in the rows. IToe often and water freely during the warm season. Cover with straw during winter.}

Green Globe French.-This is the most popular and best variety. Pkt. 5 cts., oz. 30 cts.

\section{ASPARAGUS}

German, Spargel. Sparagio. .Szparagi. One ounce for 60 feet of drill.

Culture. $-\Lambda$ convenient bed is about 6 feet wide, with a path 2 feet wide on each side. This will require six rows 1 foot 


\section{CHOICE GARDEN and FIELD SEEDS-Continued.}

apart, and a bed of that width 50 feet long will be ample for an ordinary family, requiring about one pound of seed. It will require about three years from the time of sowing until the bed is in full bearing, but once established, it is good for 20 years. It should be sown in drills 1 foot apart, and when the plants are 4 or 5 inches high they should be thinned out so that the plants will be 9 inches apart from each other in all the rows. Great care must be taken for the first year to keep down all weeds as soon as they appear, else they will choke up and desiroy the young seedling Asparagus. The deeper the soil and the more marure used, the greater will be the erop.

Barr's Mammoth.-Earlier than and nearly twice as large as Conover's Colossal; also a strong grower and very productive. Pkt. 5 ets., oz. 10 ets., 15 ets. $1 / 1 / 1$ ib., 35 ets. $1 \mathrm{lb}$.

Conover's Colossal. - The best known, and one of the most desirable sorts. Pkt. 5 ets., oz. 10 ets., 15 ets $1 / 4$ th., 35 ets. 1b.

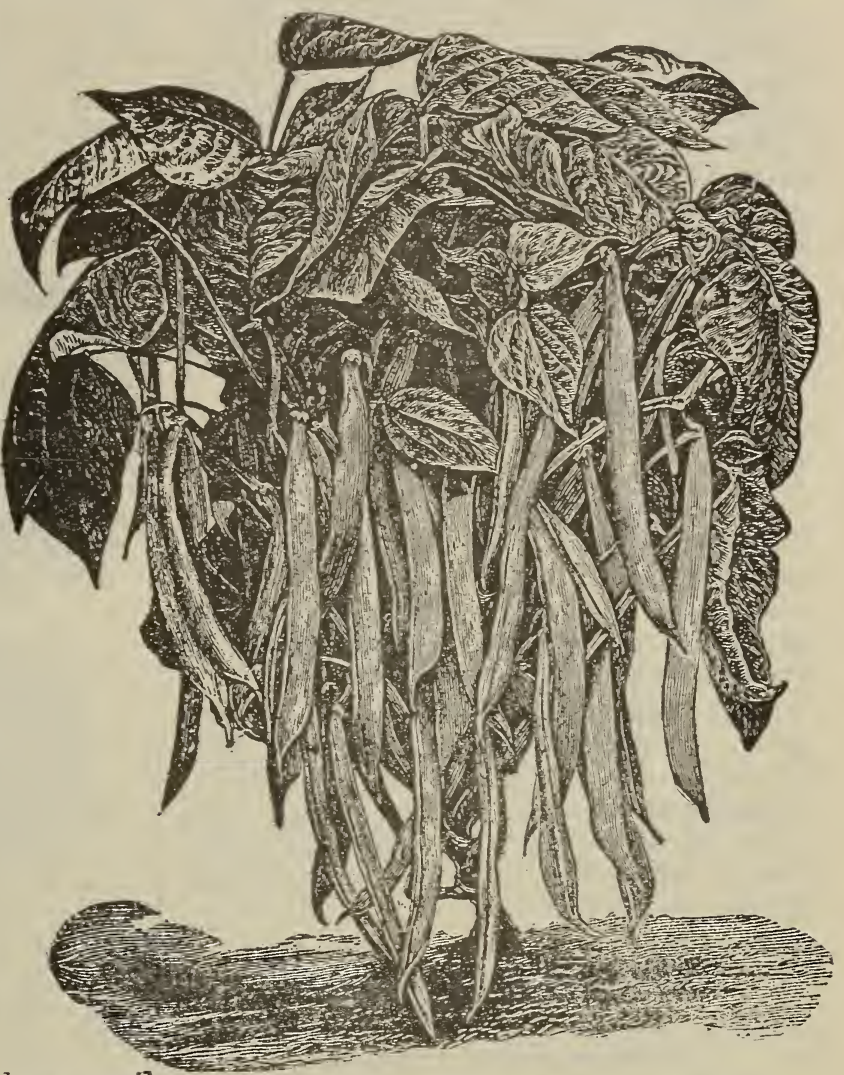

Palmeto.- Shoots are very large and light green, also tender and very desirable for the market and home garden. Very quick in growth, with close, round-topped shoots. 5 cts. Pkt., 15 cts. $1 / 4$ ib., 40 ets. 1 ib.

\section{ASPARAGUS ROOT IN SEASON}

and

\section{BEANS}

\section{DWARF OR BUSH BEANS.}

German, Bohnen. Fagnioli. Fasola.

One quart to 100 feet in drills; or 150 hills, 2 bushels to the acre, in drills.

A succession of sowings can be made ırom the first week in May until September. These dates are for the latitude of New York; farther south the sowing must be done earlier, farther north, later. Plant in drills about 2 inches deep, and from 18 inches to 2 feet apart, according to the richness of the soil; the poorer the soil the closer they can be planted. The seeds should be dropped about 2 inches apart.

Add 8 cts. per pt., 16 cts. per qt., if to be sent by mail.

\section{WARDWELL'S KIDNEY WAX. \\ WAX-POD, OR BUTTER BEANS}

Black German Wax.-(Black seed.) Very early; round, yellow pods; a well-known standard sort. Qt. 20 cts., 4 qts. 70 cts., pk. $\$ 1.25$.

Golden-eyed Wax.-Rust-proof. Very hardy and prolific; a desirable and popular sort; pods flat; a favorite with southerners who ship to northern markets. Qt. 20 ets., 4 qts. 70 ets., pk. $\$ 1.20$.

Golden Wax.-Very popular; well-known standard sorts. Qt. 20 cts., 4 qts. 70 ets., pk. $\$ 1.20$.

Davis White Kidney Wax.-Pods remarkably long, straight and handsome, waxy white color; enormously productive; seed white. Qt. 20 ets., 4 qts. 70 ets., pk. $\$ 1.20$.

Keeney's Pencil Pod Black Wax.-Long, slender pods. Qt. 20 cts., 4 qts. 70 ets., pk. $\$ 1.20$.

Kidney Wax (Wardwell's). Extra early; purely wax pods, long, flat, and remarkably free from rust. Qt. 20 cts., 4 qts. 70 cts., pk. $\$ 1.20$. 


\section{CHOICE GARDEN and FIELD SEEDS-Continued.}

\section{GREEN-PODDED DWARF BEANS}

Bush Lima, Burpee's.--Beans as large as Pole Limas; perfectly dwarf and very productive. Qt. 25 ets., 4 qts. 90 ets., pk. $\$ 1.75$.

Bush Lima, Dreer's.-Beans similar to Dreer's Pole Lima, but ten days earlier and a true Bush Bean. Qt. 25 cts., 4 qts. 90 cts., pk. $\$ 1.75$.

Burpee's Stringless Green Pod.-New. Extra early, prolific; entirely stringless; crisp, tender; fine quality. Qt. 20 cts., 4 qts. 70 cts., pk. $\$ 1.25$.

Black Valentine.-A distinct form of Valentine. 25 cts. qt., 4 qts. 80 cts., pk. $\$ 1.40$.

In quantity apply for price.

Fordhood Bush Lima-Qt. 30 cts., 4 qts. $\$ 1.25$, pk. $\$ 2.00$.

Refugee, or 1,000-to-1.-Round pod; very productive and tender; medium early. 20 ets qt., 4 qts. 75 cts., pk. \$1.25.

Iong Yellow Six Weeks.-Pods flat and green; a leading market sort in most localities. 20 cts. qt., 4 qts. 75 cts., pk. \$1.25.

Improved Early Red Valentine-Very early and one of the most popular round-pod Beans; best snap sort. 20 cts qt., 4 qts. 70 cts., pk. $\$ 1.25$.

\section{POLE OR RUNNING BEANS.}

German, Stangen Bohnen. French, Haricot a Rames. Spanish, Judias.

One quart to 150 hills; 10 to 12 quarts to the acre in drills.

These are more tender, and require rather more care in culture than the Bush Beans, and should be sown two weeks later. They succeed best in sandy loam, which should be liberally enriched with short manure in the hills, which are formed, according to the variety, from 3 to 4 feet apart. From 5 to 6 seeds are planted in each hill, about 2 inches deep. As the matured Bean is used mostly, the season is too short for succession crops in the north, though it is advantageous to plant succession crops in the southern states, where the season of growth is often from March to November. Rough cedar or similar poles about 7 or 8 feet high should be used for Lima Beans to climb on. They should be set in the ground at least 18 inches, so as to prevent being blown over.

Add 8 ets. per pt., 16 ets. per qt., if to be sent by mail.

Dreer's New Golden Cluster Wax.Early and productive; pods 6 to 8 inches long, very showy and golden yellow; seed white. 30 cts. qt., 4 qts. $\$ 1.00$.

Scarlet Runner.-A popular English va- rety. Very ornamental, wth scarlet blossoms. 25 cts. qt.

Old Homestead. - This we regard as far ahead of any. 30 cts. qt.

Lima, King of the Garden.-Heavy cropper; bean and pod very large. 25 cts. qt., 4 qts. 90 cts., pk. $\$ 1.75$.

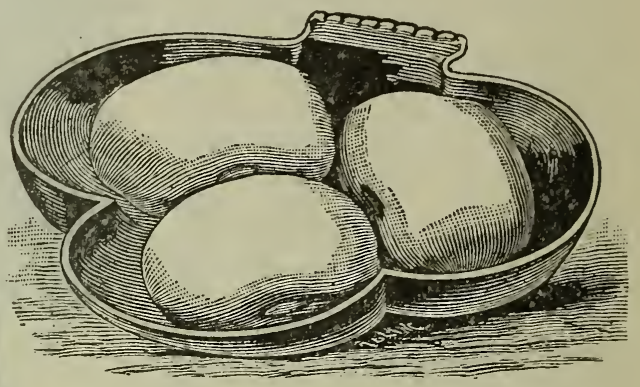

\section{DREER'S IMPROVED LIMA BEAN.}

Lima, Large White.-The standard Lima. 25 cts. qt., 4 qts. 90 cts., pk. $\$ 1.75$.

Lazy Wife.-Beans white; pods green and entirely stringless; produces an enormous quantity of pods.

Lima, Dreer's Improved.-Beans thicker and sweeter than Large Lima; very desirable. 25 cts. qt., 4 qts. 90 cts., pk. \$1.75.

Horticultural, or Cranberry.-Showy and excellent, either as a snap or shell Bean, or for cooking when dry. 30 cts. qt., 4 qts $\$ 1.00$, pk. \$1.75.

\section{BEET}

\section{German, Runfelrube. Barbabietola. Buraki.}

One ounce to 50 feet of drill; 5 to 6 pounds to the acre in drills.

The soil which is best suited is that which is rather light and thoroughly enriched with manure. For an early supply, sow in spring as soon as the ground becomes fit to work, in drills about 1 foot apart and 2 inches deep. For main crop, sow the first week in May, and for winter use sow in June.

\section{TABLE BEETS-}

Bassano, Early Flat.-An early tenđer variety; color light red. 10 cts. per oz., 15 cts. $1 / 4$ 1b., 50 ets. 15 .

Bastian's Early Blood Turnip.-Very early red variety; not quite so flat as Early Blood Turnip or Bassano; profitable either for market or home garden. 10 ets. per oz., 15 cts. 1/4 tb., 50 ets. 16.

Egyptian.-The best for early market; as early as the original strain of Egyptian, is thicker and less inclined to push up a woody neck as it advances in growth. 10 ets. per oz., 15 ets. $1 / 4$ tb., 40 cts. 16 . 


\section{CHOICE GARDEN and FIELD SEEDS-Continued.}

Detroit Dark Red.-Round; skin dark red; flesh light red, very sweet. Oz. 10 cts., $1 / 4$ lb. 20 cts., lb. 60 cts.

Half-Long Blood.-An excellent halflong, second-early Beet; good also for win. ter use. $10 \mathrm{cts}$. per oz., 20 cts. $1 / 4 \mathrm{tb} ., 60$ cts. $1 \mathrm{tb}$.

Long Smooth Blood.-Long, smooth and very dark red; a late variety. Our strain of this variety cannot be excelled. $10 \mathrm{cts}$. per oz., 15 cts. 1/t 1b., 35 cts. 1b.

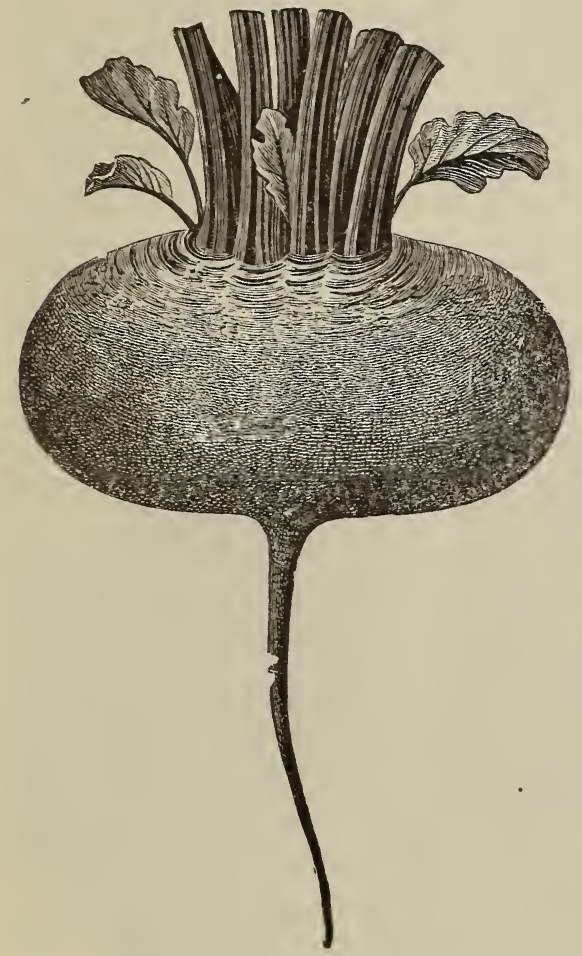

EGYPTIAN BEET.

Eclipse Blood Turnip.-Very early, round, smooth and dark red. Our strain of this variety is very select; it has a very small top, and is one of the best for market. 10 cts. per oz., 15 cts. per 1/t 1b., 50 Ib.

Swiss Chard, Silver or Sea Kale Beet. Grown exclusively for its leares. The middle of the leaf can be used and served like asparagus, the rest of the leaf like spinach. Oz. 10 cts.

\section{MANGEL-WURZEL}

6 to 8 pounds of seed will sow an acre.

CULTuRE.-The following varieties are extensively grown for feeding stock, and are excellent food to increase the flow of milk.
As they grow much larger than the varieties cultivated for table use, they require more room, and should be sown in drills about 2 feet apart. The seeds should be dropped about 2 inches apart in drills, and when strong enough, thinned out to 12 to 15 inches in the rom. The long varieties are. best suited to a deep soil, and the globe sorts succeed better than the long sorts on sandy soil.

10 cts. per oz.

Prices on all varieties of Mangels as follows: Pkt. 5 cts.

Golden Tankard.-Best and most popular for dairy farming; a very large, yellowfleshed sort, said to contain a la'rge amount of sugar; grows largely above ground, is hardy and a heavy cropper. 25 cts. per tb.

Long Red Mammoth Prize.-The most largely grown of any of the Mangels; roots attain an enormous size, producing 30 to 50 tons to the acre; quality superior; the best for deep soil. 25 cts. per 1 to.

Long Red Norbiton Giant.-Is sometimes called Jumbo, or Colossal. Tery similar to Long Red Mammoth. 30 cts. per $1 \mathrm{~b}$.

Iong Red.-This is an old-fashioned long red Mangel. 25 cts. per lb.

\section{BROCCOLI}

\section{Spargel-Kohl. Bocoli. Brokuluy.}

one ounce will sow a bed of 40 square feet, and produce about 3,000 plants.

CULTURE.-Sow the first week in May, in drills 3 or 4 inches apart, covering the seeds lightly. When the leaves are about 3 inches broad, transplant to prepared beds 2 feet apart each way. Much resembles cauli. flower. Cultivation the same.

Prices on all varieties of Broccoli as follows: Pkt. 5 icts.

White Cape.-Heads compact, of a good size, and creamy white; one of the most certain to head. 25 cts. per oz., 85 cts. $1 / 1$ tb., $\$ 3.00$ to.

\section{BRUSSELS SPROUTS}

(Species of Cabbage; cultivation the same.) German, Rosen-Kohl. Cavolo di Brusselles Latorvil.

One ounce will sow a bed of 40 square feet, and produce about 3,000 plants.

Culture.-This is a delicious regetable, superior to either borecole or spinach. The small, cabbage-like heads which grow upon the stem are much improred by a moderate 


\section{CHOICE GARDEN and FIELD SEEDS-Continued.}

frost. Sow in hotbeds in March or April, and in the open ground in May; cultivate same as broccoli.

Carter's Perfection.-A new variety of fine quality and compact growth. Pkt. 5 cts., 10 ets., oz., 50 cts. $1 / 4$ Ib., $\$ 1.50$ lb.

\section{CRESS, OR PEPPERGRASS}

German, Kresse. French, Cresson. Spanish, Mastuerzo.

One ounce will sow 16 square feet, or 150 feet of drill.

Culture.-A popular salad which should be sown early in the spring-very thickly in shallow drills-and at short intervals, for succession, as it soon runs to seed.

Extra Curled.-A small plant, having a fine, pungent flavor, and used as a salad; may be cut two or three times. Pkt. 5 cts., oz. 10 cts.

\section{WATER CRESS}

\section{German, Brunnen-Kresse. Ogretto. Rzerzucha.}

One ounce will sow 100 square feet.

CULTURE.-This wholesome salad may be grown in any moist situation, but more successfully by the edge of a running brook. The seed may be sown in May, on the ground where it is intended to be grown, and the thinning transplanted. The plants should be set not less than a foot apart. The Cress will be fit for gathering the second year.

True Water Cress.-Grows along the banks of ponds and streams, and is easily introduced; wholly unlike Extra Curled; leaves are quite large and thick; a fine salad, sold in immense quantities in the large markets in spring. 25 cts. per oz., 75 cts. $1 / 4$ 1n., $\$ 2.50 \mathrm{lb}$.

Extra Curled, 10 cts. oz., 15 cts. $1 / 4$ lb., 50 cts. 16 .

\section{CHICORY}

\section{German, Aichorie. Cicoria selvatica.} Cukorya.

One ounce will sow a bed of 4 square yards.

Chicory is cultivated for its roots, which are dried, and used as a substitute or flavoring ingredient for coffee. The leaves, when blanched, are also esteemed as a salad. Cultivate as recommended for carrots.

Large-rooted.-The dried roots are roasted and mixed with coffee, or used as a substitute. Pkt. 5 cts., oz. 10 cts.

\section{CABBAGE}

German, Kohl. Corvolo coppuccio. Kopusta.

Culture.-Soil for Cabbage should be rich and heavy loam, with good drainage. On such a soil, with an abundance of stable manure, excellent crops are sure to ba giown. For early spring, sow in fall, not too early, or the plants are liable to bolt in the spring instead of heading. In a month the plants will be fit to transplant to coldframes, where they are wintered, taking care in planting to set the young plants down to the firsi leaves. Transplant in spring as soon as the ground can be worked, setting the plants 2 feet apart one way and from 12 to 18 inches the other, according to the variety. If it is desirable to economize space, lettuce or radish may be sown between the roms, as they will be out of the way before the Cabbage needs the room. For late or irinter crops, the seed is sown in May anc? the plants set out in July. In this case they are set in rows $2 \times 3$ feet, so as to work them with a horse and cultivator. To prevent the turnip-flea attacking the young plants, sifi fine air-slaked lime or tobacco dust over them as soon as they appear above ground.

Special prices on quantities.

Charleston Large Wakefield.-Popular with market-gardeners in the south. This strain is about a week later than the Early Jersey Wakefield, but the heads are fully one-half larger; will not burst when ripe, like most early sorts, and can be left standing in the field some time without damage. 15 cts. oz., 50 cts. $1 / 4$ it., $\$ 1.50$ it.

Danish Ballhead.-One of the very best winter sorts; heads round and very solid. Pkt. 5 ets., 25 ets. per oz., 75 ets. $1 / 4$ tb., $\$ 2.50$ it

Early Improved Summer.-Heads are large, round and very compact; about ten

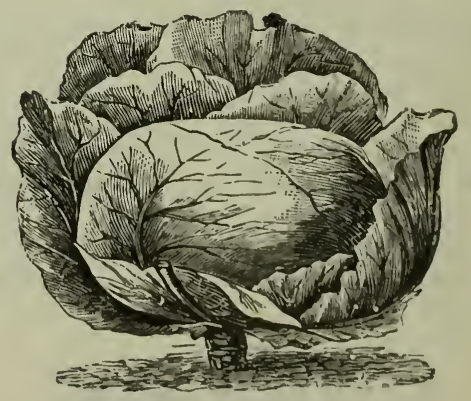

EARLY IMIPROYED SUMIIER CABBAGE.

days later than Jersey Wakefield; one of the earliest large-heading varieties. 15 cts. per oz., 40 ets. $1 / 4$ tb., $\$ 1.50 \mathrm{lb}$.

Henderson's Succession.-One of the best 


\section{CHOICE GARDEN and FIELD SEEDS-Continued.}

of Cabbages; heads rery large and somewhat Hat; ten days later than Early Sum. mer: much prized br gardeners. 20 cts. oz., 60 cts. $1_{t}$ lb., $\$ 2.00 \mathrm{lb}$.

Large Late Drumhead.-Heads large, flat, solid, and a good keeper; planted for main crop for winter keeping. 15 cts. per oz., 40 cts. 1/4 tb., $\$ 1.50$ 1b.

Savoy Perfection Drumhead.-This is the bes of the Saroys for market or family use; heads large, with crisp, wrinkled leares; it nearly approaches the cauliflower in fine flaror. 15 cts. per oz., 40 cts. $1 / 4 \mathrm{lb}$.. $\$ 1.50 \mathrm{Hb}$.

Red Dutch.-The best known of the red Cabbages; much used for pickling. 15 cts. per oz., 10 cts. $1 / 4$ lb., $\$ 1.50$ lb.

Rice's Premium Late Flat Dutch.-A justly popular and esteemed rariety; extensirely cultirated for market and family use;

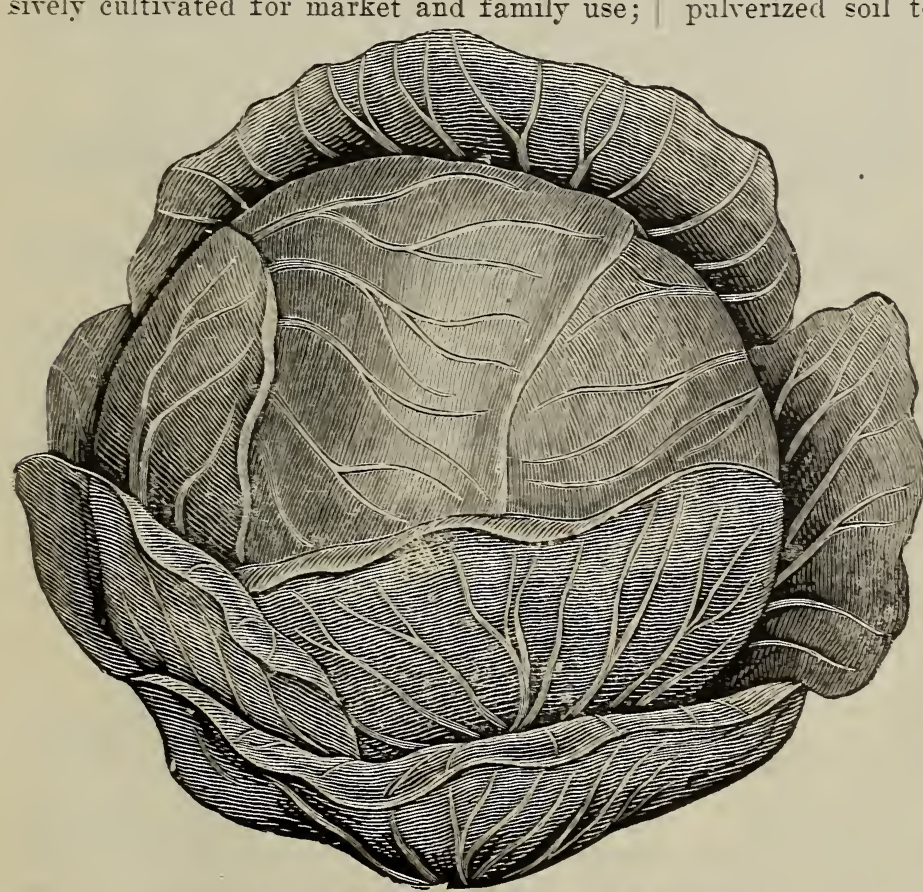

RICE'S PREMIUM LATE FLA'T DUTCH. $16 ., \$ 1.25 \mathrm{lt}$.

rieties fail entirely; heads cone-shaped, and a good keeper. 10 cts. per oz., 40 cts. $1 / 4$

Rice's Surehead.-All head and always sure to head; this rery popular variety is rightly named Surehead, because it never fails to form a good solid head, even on poor soil, but the richer the soil the larger and finer the head; it is the finest late Cabbage in this country, and best for market. Heads the list for winter use. 15 cts. per oz., 40 ets $1 / 4$ tb., $\$ 1.50$ lb.

\section{CARROT}

German, Mohre. Carorto. Marchew. One ounce will sow 100 feet of drill; 3 pounds required for an acre.

Culture.-Carrots require a rery finely pulverized soil to grow them to perfection. A good, light and well. enriched sandy loam is the best for this crop. For field culture, sow in drills three to three and one-half feet apart, so as to cultivate by horse. Market gardeners sow in drills, about 18 inches apart, and cultivate by hand. For early crops corer one-half inch deep, and thin . to 6 inches apart in the rows; for late, corer three-quarters inches deep, and thin to 4 inches.

Prices in quantity on application.

Chantenay Half-Long. -Stump-rooted; broad, thick shoulders; heavy cropper. Oz. 10 cts., qt. 20 cts., lb. 60 cts.

Danvers Half-Long.One of the heaviest crop. pers; roots dark orangecolor, 8 to 10 inches in length, thick, and ending

a good keeper. Per oz. 15 cts., 1/4 1b. 40 cts., It $\$ 1.50$.

Rice's Selected Early Jersey Wakefield. This is the most widely known and popular early varistr. Heads are cone-shaped and ver solid. 15 cts. per oz., 50 ets. $1 / 4$ 1b., $\$ 1.50$ per 16 .

Rice's Fine Early Winnigstadt.-Ninetynine plants in every hundred war:anted to head up hard and fine. One of the best for either early or late use; it rarely fails to form good. solid heads, eren where other ra- in a somewhat abrupt point; first-class for all soi's. Oz. 10 cts., qt. 20 cts., lb. 60 cts.

Early Scarlet Horm.-A rery popular sort quick-growing: deep orange in color; blunt-rooted; 6 to 8 inches in length: Per oz. 10 ets., 1/1 1b. 20 cts., 1b. 60 cts.

Improved Long Orange.-The best known and most largely cultirated of any Carrot; excellent for stock or table use; roots deep orange. 12 to 15 inches long. Per oz. 10 ets., $1 / 4$ to. 15 cts., tb. 50 cts. 


\section{CHOICE GARDEN and FIELD SEEDS-Continued.}

\section{CAULIFLOWER}

\author{
German, Blumenkfohl. Covolfiore. \\ Kalafiory.
}

One ounce will sow a bed of 40 square feet, and produce about 3,000 plants.

Culture. - When grown to perfection this is a most delicious vegetable, and well re. pays generous treatment in cultivation. With a deep rich soil, and an abundance of moisture, which in dry seasons must be ap. plied artificially, Cauliflower can be grown well. The cultivation is similar to that of the cabbage. For early fall crops, sow in May, and transplant in June, in rows 4 feet apart, setting the plants 2 feet apart in the row; water frequently if the ground be dry. Frequent hoeing and a liberal supply of rich liquid manure, to keep up a continuous and rapid growth, will produce splendid heads of the most delicate Havor. It facilitates blanching if the leaves are gathered loosely together and tied over the top of the head to protect from the sun. Cut before the flowers begin to open. Sow as late as June 20 for late crops, in beds or in hills, covering one-half inch deep. Forms a large head, which is solid, crisp, and tender, and will form heads under more un. favorable conditions than any other. We urge you to try it. Pkt. 5 cts., oz. $\$ 1$.

Henderson's Early Snowball.-This is undoubtedly the finest variety ever introduced; it is the earliest, and produces beautiful snow-white heads of the most delicious flavor. The seed we offer is pure and genuine, and sure to prove satisfactory. 20 cts per pkt., $\$ 2.00$ oz.

Early London.-A good sort. $10 \mathrm{cts}$. per pkt., 60 cts. per oz.

\section{CELERY}

\section{German, Cellerie. Sedano. Selery.}

One ounce will produce 7,000 plants.

Culture. - Sow seeds in a hotbed or coldframe. As soon as the plants are about 3 inches high, transplant to a nicely prepared bed in the border, setting them 4 or 5 inches apart. When about 8 inches high, and fine, stocky plants, set them in the trenches. Earth up a little during the summer, keeping the leaf-stalks close together, so that the soil cannot get between them. Finish earthing up in autumn, and never hoe or earth up in moist weather, nor when the plants are moistened with dew.

To preserve Celery for winter, dig trenches 1 foot in width and as deep as the tops of the plants. Stand the Celery in these, erect as they grew, with what dirt adheres to the roots, packing closely, but not crowding. After the trench is filled it should be covered with straw or leaves as a protection from frost. Do not cover until the weather becomes quite cold, and then only a little at a time, as the cold becomes greater. Celery will bear a good deal of frost. The trench must have good drainage.

Boston Barket.-Popular in the markets of Boston; a strong grower; remarkably tender and crisp. 15 cts. per oz., 50 cts. per $1 / 4 \mathrm{lb} ., \$ 1.50 \mathrm{lb}$.

Dwarf Golden Heart.-Resembles the Half-Dwarf White in habit of growth; very solid, and the heart is of a golden yellow when blanched; excellent keeper, and fine for garden or market. 15 cts. pe: oz., 45 cts. $1 / 4$ to., $\$ 1.50$ tb.

Dwarf Golden Self-blanching.-Our strain of this variety is unexcelled and absolutely reliable; this sort is, without doubt, the finest early Celery in cultivation. It is perfectly solid, of a fine, nutty flavor; attains a good size, and when blanched is of a handsome golden yellow color. 40 cts. oz., $\$ 1.251 / 4 \mathrm{lb}$.

Giant Paschal. -15 cts. per oz., 45 cts. 1/4 1b., $\$ 1.50$ 1b.

Henderson's Improved White PIume.A well-known and perhaps the most popular variety of Celery; very early, ornamenta; and, for quality, surpassed by none; has great merit as an early market sort. 20 cts. per oz., 60 cts. $1 / 4$ lb., $\$ 2.25$ lb. ib.

Celery for Flavoring only. -40 ets. per

\section{CELERIAC}

\section{Turnip-Rooted Celery.}

German, Knollen Cellerie. Knoll-Sellerie, Sedano-rope.

Brukwiaina.

Culture.-A variety of Celery with tur. nip-shaped roots, which are white-fleshed, comparatively tender, and have the flaror of celery stalks. The seed may be sown in the open ground in April, and the young plants nursed in the same way as celery; but in planting out the ground is manured and dug, not trenched, and the plants are set in shallow drills 12 inches apart, watering freely. As the growth advances, draw the earth to the plants. by which the knotty roots will be blanched and made delicate and tender.

Large Smooth Prague.-An improved form of Turnip-rooted Celery; round, smooth roots, with very few side roots. This is the largest variety, and one of the very best. 20 cts. per oz., 45 cts. qt., $\$ 1.50$ lb. 


\section{CHOICE GARDEN and FIELD SEEDS-Continued.}

\section{CORN, SUGAR}

\section{German, Melschkorn. Kukurudza.}

One quart will plant 200 hills; 1 peck will plant 1 acre in hills.

Culture.-Corn requires a good soil and a warm situation. Commence for first early by planting the early varieties about May 1 , and if a continuous supply is wanted all summer, make plantings about two weeks apart from Mar 1 until the last of July, first planting early varieties, then later ones. Plant in rows 3 feet apart, and make
Perry's Hybrid.-A popular variety; large, 12-rowed ears; matures a little later than Minnesota. 15 cts. qt., 4 qts. 50 cts., pk. 90 cts.

Burlington Hybrid. 15 cts. qt., 4 qts. 45 cts.

\section{LATE SUGAR CORN.}

Country Gentleman.-Very distinct from any other sort; sometimes yields as many as five ears on a stalk; cob very small, with deep kernels of pearly whiteness. This is considered the finest of all Sweet Corn; the quality is delicious, and will delight the most fastidious epicure. Qt. 15 cts., 4 qts. 50 cts., pk. 90 cts.

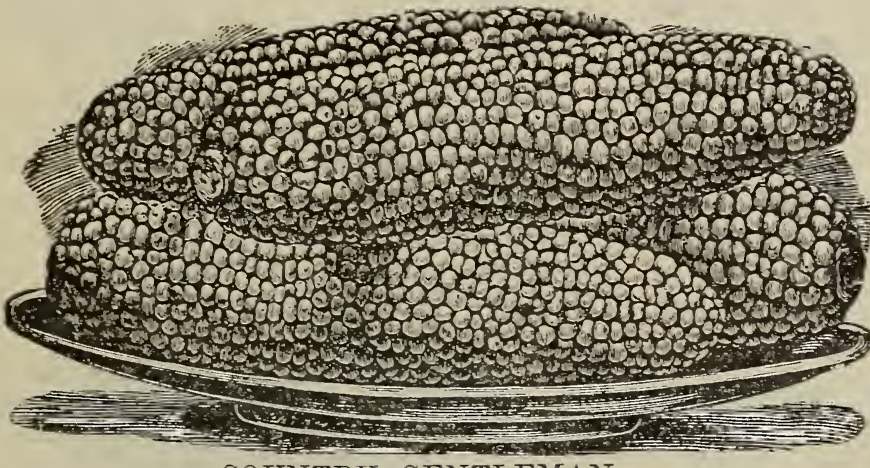

COUNTRY GENTLEMAN. the hills about the same distance apart in the rows. Fire kernals in the hills are plenty. Corer about 1 inch deep for early, and a little deeper for late. Thin to three plants in a hill.

Add 5 cts. per pt., 10 cts. per qt., if to be sent by mail.

Prices on all rarieties of Sugar Corn as follows: Pkt. 5 cts., pt. 15 cts.. qt. 25

cts. Prices in quantity on application.

\section{EXTRA-EARLY SUGAR CORN.}

Golden Bantam.-Extremely early yellow variety of delicious flavor. Qt. 20 cts., 4 qts. 60 cts., pk. $\$ 1.00$.

Early Premo.-Fair-sized ears. Quite sweet and rerr tender. 15 cts qt., 4 qts. 50 ets., pk. $\$ 1.00^{\circ}$

\section{SECOND-EARLY SUGAR CORN.}

Ferry Early Evergreen.-Qt. I5 cts.. 4 qts. 50 cts., pk. 90 cts.

Kendal's Early Giant.-An elegant rariety. Under high cultivation ears of this variety frequently grow 10 to 12 inches in length. 20 cts. qt., 4 qts. 50 cts., pk. 90 cts.

\section{MEDIUIM-EARIY SUGAR CORN.}

Black Mexican.-One of the sweetest and best rarieties: grains black when ripe, but when in condition for the table, cooks remarkably white. 20 cts. qt.
Egyptian.-Somewhat later than Evergreen; fine, large ears; makes a fine canning variety. Qt. 20 cts., 4 qts. 60 cts., pk. $\$ 1.00$.

Late Mammoth.-The largest and latest $\nabla a$ riety; ears of immense size, grains large and broad; quality of the best. Qt. 20 cts., 4 qts. 60 cts., pk. $\$ 1.00$.

Stowell's Evergreen.-

The standard for qual. ity, and the best wellknown rariety; a farorite alike with canners and market men; remains a long time in condition suitable for boiling. Qt. 15 cts.. 4 qts. 55 cts., pk. $\$ 1.00$.

\section{FODDER CORN.}

Prices for all rarieties of Fodder Corn on application.

Evergreen Sweet Fodder.-Purely a sweet Corn, and the best of all Corn for fod. der. Grows to an immense size, with abundance of leares, both leares and stalks being verr sweet and rich in saecharine matter.

Improved Leaming Ensilage. POP CORN.

White Rice.-Shelled or on the ear. Per 1v. 10 cts.

\section{CORN SALAD, OR FETTICUS}

German, Uchersalat. French, Mache. Spanish, Ma ha Valerianilla.

One ounce will sow 150 feet of drill.

CuLture.-This excellent salad may be had the rear round. Sow in September in drill $\&$ inches apart, corering the seeds lightly, and protect from frost by a light corering of hay or litter. This seed may also be sown in spring.

Large-seeded Dutch. Pkt. 5 cts., oz. 10 cts.. 1/4 to. 15 cts.. 1b. 50 cts.

Small-seeded Dutch.-Pkt. 5 cts., oz. 10 cts., $1 / 4$ tb. 20 cts., to. 50 cts. 


\section{CHOICE GARDEN and FIE CUCUMBER}

German, Curke. Cetriolo. Ogorck.

One ounce will plant 50 hills; 2 pounds will plant an acre.

Culture.-For earliest use, sow the seed in the hotbed or greenhouse in February or March, in warm loam, where the temperature is about 90 degrees; cover half an inch deep, and, when the plants are of fair size, transplant into hills (made in the greenhouse), four plants in a hill, so that when the weather permits the whole hill can be moved to the open ground by means oi tins made for that purpose. Plant for gen. eral use in the open ground, about June 1, in hills 6 feet apart each way, and thin to three plants in a hill. Fine old manure (about 6 cords per acre) is sufficient; or. better still, plant on land from which a crop has been taken, and which was heavily manured for that crop. A sprinkling of dry plaster will keep off the striped bug. Get our special prices for large quantities.

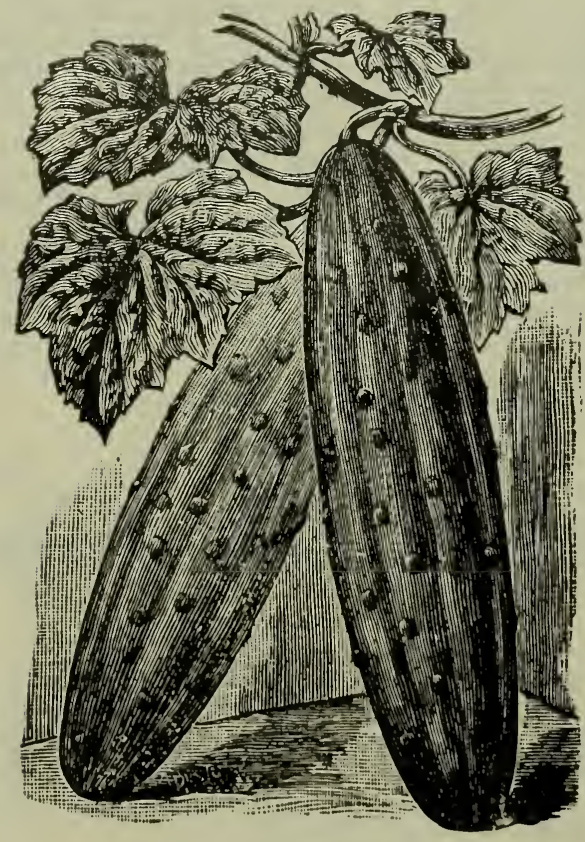

IMPROVED LONG GREEN.

Cumberland.-Fruit straight; flesh firm, but crisp and tender. One of the best for pic

pickling. 10 cts per oz., 35 cts. $1 / 4$ Ib., $\$ 1.00$

Green Prolific.-One of the best pickling sorts. Small and very brittle. 10 cts per oz., 25 cts. $1 / 4$ lb., 75 cts. lb.

Long Green Improved.-Fine for pickling when small; also good for table use when about half grown. 10 ets. per oz., 25 cts $1 / 4$ lb., 75 cts. lb.

Fordhook Famous.-One of the best of the long green type. Pkt. 5 cts., 10 cts. oz., 25 ets. $1 / 4$ lb., 75 ets. $1 \mathrm{~b}$.

Davis Perfect.-The new dark green White Spine. 10 ets. 0z., 35 cts. $1 / 4$ lb., $\$ 1.00 \mathrm{ib}$.

Early Cluster.-Fruit small and borne in pairs; light green and a great bearer; a well-known standard sort. 10 cts. oz., 25 cts. $1 / 4$ ib., 75 ets. 1b.

West India Gherkin.-The only genuine Gherkin. Small, oval and covered with spines; color light green; lised exclusively for pickling. $10 \mathrm{cts}$. oz., 50 cts. $1 / 4 \mathrm{lb}$.

White Spine, Arlington Improved.One of the finest Cucumbers for forcing, and one of the most perfect in shape, size, color and quality; very brittle and crisp. 10 ets. oz. 35 cts. 1/4 lb., \$1.00 lb.

White Spine, Improved Early.-The most popular strain of White Spine; best for general outdoor culture. 10 cts. oz., 25 cts. $1 / t$ lb., 75 cts. lb.

\section{ENDIVE}

German, Endivie. Endywia. Endiven.

Culture.-Endive is one of the best salads for fall and winter use. Sow for an early supply about the middle of April. As it is used mostly in the fall months, the main sowings are made in June and July. Plant 1 foot apart each way. When the plant has attained its full size, gather up the leaves and tie them by their tips in a conical form. This excludes the light and air from the inner leaves, which, in the course of from three to six weeks, become blanched.

Prices on all varieties as follows:

Green Curled.-Beautifully curled, ten. der and crisp. 10 cts. oz., 35 cts. $1 / 4 \mathrm{lb}$., $\$ 1.00$ tb.

White Cured.-For early use; should bo used when young. 10 cts. oz., 35 cts. 1/4 ib., $\$ 1.00$ it. 


\section{CHOICE GARDEN and FIELD SEEDS-Continued. EGGPLANT \\ GOURD}

\section{German, Eierpanze. Petronciana. Jajokowa.}

One ounce for 1,000 plants.

ClLture.-The Eggplant will thrive well in any good garden soil, but will repay good treatment. The seeds should be sown in hotbed or warm greenhouse in Miarch or April, and when about an inch high potted. in 2-inch pots. Plant out about June 1,

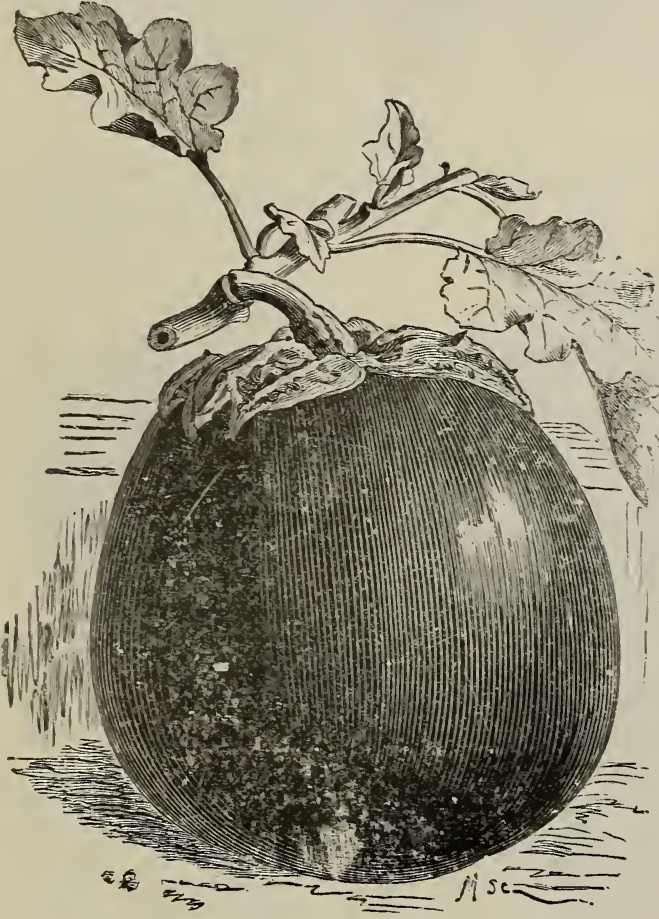

NEW YORK IMPROVED EGG PLANT.

21.2 feet apart. If no hotbed is at hand, they can be grown in any light room where the temperature will arerage 75 degrees.
Black Beauty.-

The earliest large variety; color rich dark purple. Oz. 40 cts., $1 / 4 \quad$ lb. $\$ 1.25$, lb. $\$ 4.00$.

New York Im. proved Purple.The leading market variety, and undoubtedly the best for size, quality and productiveness. $\quad 35$ ets. oz., $\$ 1.00 \quad 1 / 4$ lb., $\$ 3.75 \mathrm{lb}$.

\author{
One ounce will plant 25 hills.
}

Culture.-Gourds are tender annuals, and should not be planted until all danger of frost is over, and not less than 6 feet apart each way, in good rich loam. Three plants in a hill will be sufficient to leave at the last hoeing.

Prices as follows, except where othermise noted: Pkt. 5 cts., oz. 20 cts.

Dipper.-This, like the Sugar Trough, has a thin but hard shell, and can readils be made to serve useful purposes.

Japanese Nest-Egg.-Fruit small and creamy white; it exactly resembles the eggs of a hen. Pkt. 5 cts., oz. 25 cts.

\section{HERBS}

\section{SWEET, POT and MEDICINAL.}

CULTLRE.-The seeds should be somn in epring, in shallow drills, 12 inches apart, and the young plants thinned out or transplanted to about 4 inches. They should be harrested on a dry day, just before the blossom develops, dried quickly and bottled, or closely packed in dry boxes, with the air entirely excluded.

Dill.- Used for flaroring pickles. Pkt. J cts., oz. 10 cts., 20 cts. $1 / 416$.

Lavender.-Leares rery fragrant. Pkt. 5 cts., 0z. 15 cts.

Sage.-A highly aromatic herb; most useful of all. Pkt. 5 cts., oz. 20 cts.

Sweet Marjoram.-Used as a seasoning. Pkt. 5 cts., oz. 20 cts.

Summer Savory.-Used as a culinary herb. Pkt. 5 cts., oz. 10 cts.

Thyme.-Used as a seasoning. Pkt. 5 ets., oz. 30 ets.

Wormwood.-Has medicinal qualities. A splendid plant for poultry; should be planted in all poultry rards. Pkt. 5 cts., oz. 20 cts.

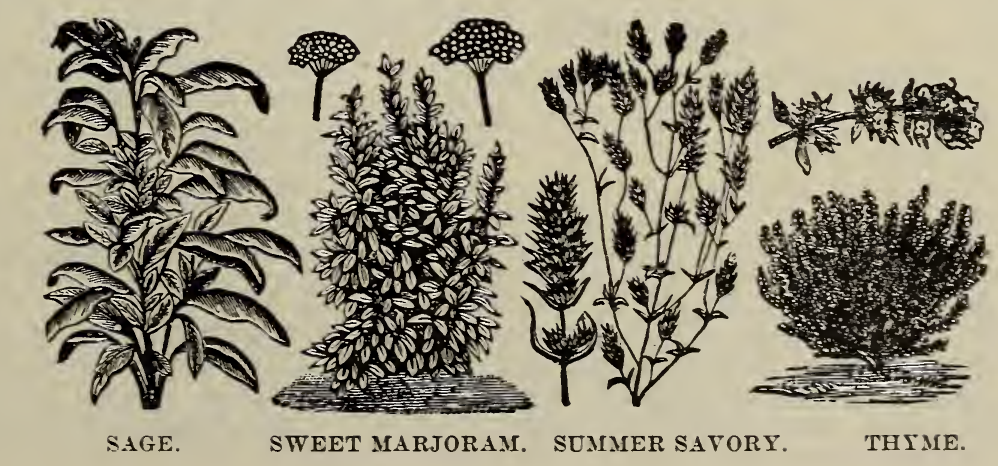




\section{CHOICE GARDEN and FIELD SEEDS-Continued. KALE, OR BORECOLE LEEK}

German, Blatter-Kohl. French, Chou Vert. Spanish, Breton.

One ounce will produce 3,000 plants.

CUlTuRE.- -Sow from the middle of April to the beginning of May in prepared beds; transplant in June, and treat in the same manner as for cabbage. Of all the caobage tribe, this is the most tender and delicate, and would be much more extensively grown than it is if its excellent qualities were generally known. The varieties are all ex. tremely hardy, and are best when touched by frost.

Dwarf Green Curled Scotch.-Rareiy exceeding 18 inches in height, but spreading out under good cultivation to 3 feet in diameter; leaves beautifully curled and bright green. 10 ets oz., 15 cts. 1/4 1b.. 50 cts. $1 \mathrm{~b}$.

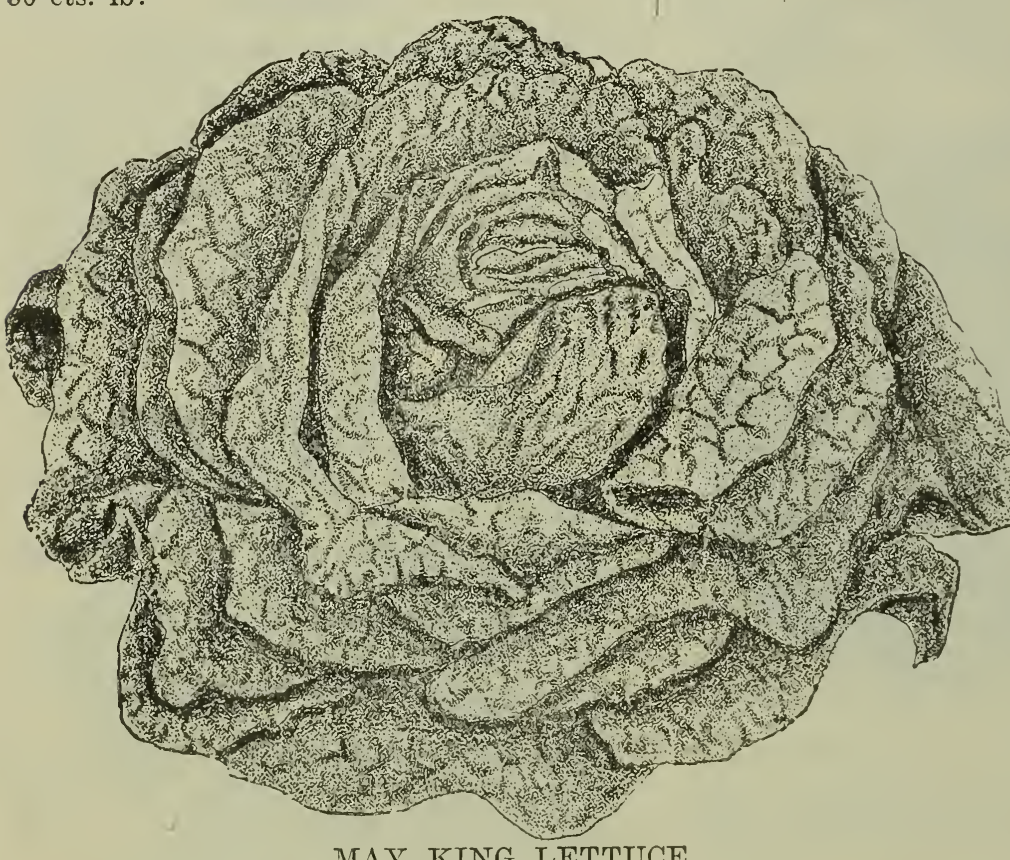

German, Lauch. Spanish, Puerro.

One ounce will plant 200 feet of drill.

Culture-The Leek is very hardy and easily cultivated; it succeeds best in a light but well enricheri soil. Sow as early in the spring as practicable, in drills an inch deep and 1 foot apart. When 6 or 8 inches high transplant in rows 10 inches apart each way, as deep as possible, that the neck, being covered, may be blanched.

Large London Flag.-The oldest and best-known and most largely grown variety. Oz. 15c., 1/4 lb. 35c., lb. $\$ 1.00$.

\section{LETTUCE}

German. Lattich. Koppolet. Lattuga Salat. One ounce will sow 100 square feet, or 120 feet of drill.

Culture. - Requires a rich, moist soil, and to be crisp and tender needs to be grown in cool weather. For winter use, sorr in hotbeds every two weeks, at the rate of on ounce of seed to four sashes (a sash is 3 feet long by 6 feet wide; cover very lightly, and transplant first to 3 inches apart each way, afterward to $S$ inches. For garden or field, sow in rows, and cover onefourth of an inch deep, and thin out to 12 inches apart

KOHLRABI

(TURNIP-ROOTED CABBAGE.)

German, Kohl-Rabi. Cavolo ropa. Kolorapa.

One ounce will sow 200 feet of drill.

CulturE.-This vegetable, the popularity of which is rapiclly increasing, combines the virtues of the turnip and cabbage, but excels both in nutritive, hardy and productive qualities. The seed may be sown in June, in rows 18 inches apart, and the plants thinned out to 8 or 10 inches in the rows.

Early White Vienna.-Best for general table use; flesh tender and white. Pkt. 5 ets., oz. 15 cts., 35 cts $1 / 4$ ib., $\$ 1.00$ ib. in the rows. For New England, the White-seeded Tennisball, for eultivation under' glass, and the Black-seederl 'Temisball, for outdoor use, are the standard varieties.

Iceberg.-New. Of beautiful appearance and exeellent quality; leares green, slightly tinter with red at the edge; heads of good size and solir. Oz. 10c., 1/4 lb. $35 \mathrm{c}$., 1b. $\$ 1.25$.

May King.-Heads extra large and so:id; green outside, but heart clear yellow; very desirable. Oz. 10c., 1/4 lb. 35c., 1b. \$1.25.

Big Boston.-A most ilesirable variety, either for forcing in cold frames or open- 


\section{CHOICE GARDEN and FIELD SEEDS-Continued.}

ground planting; always produces large, solid, salable heads. Oz. 10c., 1/4 1b. 35c., lb. $\$ 1.25$.

Immensity.-New. The largest head Let tuce in the world. Tender, sweet and crisp. Oz. 10 cts., 1/4 lb. 35c., lb. $\$ 1.25$.

Salamander.-Fine, compact heads, which resist summer heat admirably; rery popular in some sections. Oz. $10 \mathrm{c} ., 1 / 4$ lb. $35 \mathrm{c} ., 1 \mathrm{~b}$. $\$ 1.00$.

Silesia Early Curled.-Early and tender; leares rellowish green; good for the home or market-garden. Oz. $10 \mathrm{c} ., 1_{ \pm}$lb. $35 \mathrm{c}$., lb. $\$ 1$.

Yellow seeded Butter.-A fine rellow tender lettuce. Oz. 10c., 1/4 lb. 35c., lb. \$1.00.

\section{MELON, MUSK}

German, Melone. Popone. Meton.

One ounce will plant about 80 hills.

Culture-A rich, deep, sandy loam, well worked and highly manured with old rotten compost, is of the first importance. Plant

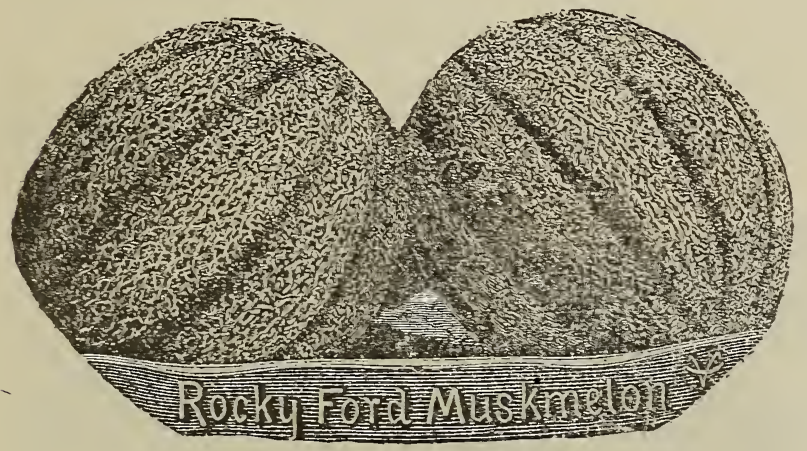
cts. $1 \mathrm{~b}$. growth of the vines, and the fruit will come eariier to maturity.

Prices on all rarieties of Muskmelons as follows, except where otherwise noted: Pkt. j cts., oz. 10 ets. Ask for our prices on larger quantities.

Burpee's, or Golden-netted Gem.-One of the finest varieties for hotels and restaurants; shape nearly round; color dark green, and thickly netted; flesh light green and rery delicious; very early. Size very uniform, the melons weighing from $11-2$ to 2 lbs. Oz. 10 cts., 1/4 lb. 25 cts., lb. 75 cts.

Pine Apple.-Extra fine variety. $10 \mathrm{cts}$, oz., 25 cts. $1 / 4$ lb., 75 cts., lb.

Chicago Market.-A large and excellent green-fleshed Nutmeg; round and flattened at the ends; one of the leading market melons of Chicago. 10 cts. oz., 25 cts. $1 / 4$ lb., 75

Emerald Gem.-One of the very earliest rarieties; fruit small, skin deep emerald green; flesh a handsome salmon-color and very thick; fiavor most delicious; a splendic melon for hotels and restaurants. $10 \mathrm{cts}$. $0 z ., 20 \mathrm{cts} .1 / 4$ lo., 70 cts. $1 \mathrm{~b}$.

Hackensack, or Turk's Cap. -Fruit large, round and flat tened at the ends, deeply ribbed and heavily netted; flesh green, thick and of very fine flavor. A fine market variety. $10 \mathrm{cts}$ oz., 20 cts. $1 / 4$ lb., 65 cts. lb.

Jenny Iind.-An extraearly, small, green-fleshed melon of fine flavor; round and flattened at the ends. 10 cts. when all danger of frost is orer, in hills 5 to 6 feet apart each war; scatter a dozen seeds to a hill, and after they are out of danger from bugs, thin to three or four plants. Then they hare four or five rough leares, pinch off the end of the main shoot. which will cause the lateral branches to put forth sooner. This will strengthen the oz., 20 cts., $1 / 4$ lb., 75 cts. lb.

Long Island Beauty.-Of the Hackensack type, but superior in quality. 10 cts. oz. 25 cts. $1 / 4.1 b ., 75$ cts. lb.

Rocky Ford.-An improved and oblong form of the Netted Gem. A most excellent green-fleshed sort. $10 \mathrm{cts}$. oz., 20 cts. $1 / 4 \mathrm{lb}$., 75 cts. Ib.

\section{PRIZE OFFERS--\$10.00 IN GOLD}

$\$ 5.00$ in gold for the mnest bunch of six "Early Scarlet Turnip Radishes," tops attached, delivered to our store on Friday, May 12, 1911.

\section{$\$ 5.00$ IN GOLD}

For the finest ear of "Stowell's Erergreen Sweet Corn", delivered to our store on Friday, the 25th day of August, 1911.

\section{CONDITIONS.}

The only conditions are that the regetables be raised from seed bought at Satterthwaite's Seed Store in the season of 1911. Competitors are limited to one exhibit for each prize contested for.

\section{JUDGES.}

The Judges will be John R. Satterthwaite and two farmers or truckers selected to assist him. The names of contestants will not appear on the exbibits at the time the Judges pass on them, but only numbers. 


\section{CHOICE GARDEN and FIELD SEEDS-Continued.}

\section{MELON, WATER}

German, Wassermelone. Meloni d'aqua. Melon Wodny.

One ounce will plant 50 hills.

CulTure.-Watermelons are cultivated in hills, which should be 6 to 8 feet apart each way, and composed of light, moderately rich soil. The hills should be dug 2 feet square, 18 inches deep, and half filled with wellrotted manure. which must be thoroughly incorporated with the soil. Plant in May, ten seeds to a hill, and when the plants are well up, thin out to three. Cultivate until the vines cover the ground, and pinch the ends of the growing shoots to induce early fruiting.

Get our prices for larger quantities.

Cole's Early.--Very hardy, a sure cropper and extremely delicate in texture or flesh. Medium size, nearly round in shape; flesh dark red, rind green, striped with lighter shades. 10c. oz., 15c. 1/4 lb., 50c. lb.

Cuban Queen.-One of the best for shipping; a good keeper; grows to enormous size, and is very productive; rind light and dark green; flesh bright red, solid, crisp and sugary; oblong. 10 cts. oz., 15 cts. $1 / 4$ lb., 50 cts. lb.

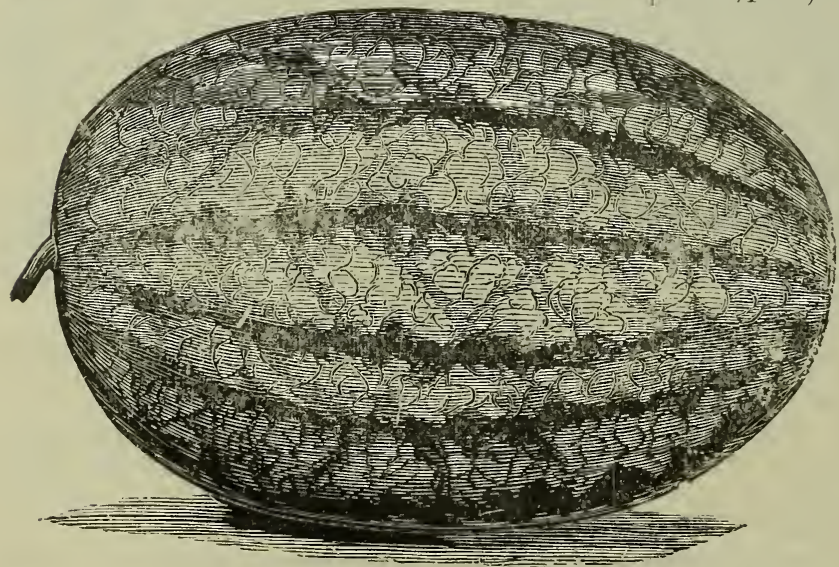

CUBAN QUEEN WATERMELON.

Dixie.-The finest; a cross between Kolb Gem and Mountain Sweet, surpassing the former as a shipper and the latter in luscious sweetness and delightful flavor; best for shipping, finest for quality; largest, most productive Watermelon. Much longer than Kolb Gem; rind darker and more beantifully striped. 10 cts., oz., 15 ets., 1/t liv., 50 ets. lb.

Florida Favorite.-Highly prized for its iclicious flavor; large, oblong; rind dark green, with stripes of lighter green; ten days earlier than Kolb Gem. 10 cts. oz., 20 cts. I' lh., 60 ets. lb.
Iceberg. Similar in shape and size to Kolb Gem, but darker in color. 10 cts. oz., 15 ets. $1 / 4$ lb., 50 ets. lb.

Icing, or Ice Rind.-(Light-skinned.) Tiound; rind light green; fiavor rich and sweet, and a good shipper. 10 cts. oz., 15 cts. $1 / 4$ lb. 50 ets. lb.

Kolb Gem.-Originated in Alabama, and more largely grown in the South than any other melon; as a shipping variety has no superior; rind dark green, mottled; shape nearly round; quality superb. 10 ets. oz., 20 cts. $1 / 4$ lb., 50 cts. 1 b.

The Kleckley Sweet.-This famous "sweetest of all" Watermelons has become very popular; of superb luscious flavor, very fine grained and tender meat. The fruits are of large size; the rind is very thin and brittle, splitting ahead of the knife when cutting. 10c. oz., 25c. 1/4 lb., 75c. lb.

Long Light Icing.-Grows to a very large size; rind mottled gray; flesh crimson and very fine; shape oblong. 10 ets. oz., $15 \mathrm{cts}$. $1 / 4$ lb., 50 cts. lb.

Fordhook Early.-Good grower. 10 cts. oz., 1.5 cts. $1 / 4$ lb., 50 ets. 1 b.

Mountain Sweet.-Old, but still the standard of excellence for quality; fruit long and very rlark green. 10 cts. oz., 15 ets. $1 / 4$ lb., 40 ets. lb.

Seminole.-This melon has the peculiar distinction of being of two distinct colorsgray and light green; melons of both colors are exactly alike in shape, size, color of seea and all other points except color of skin; it is oblong. large. enormously productive, and of very superior quality. I0 ets. oz., 20 cts. $1 / 4$ lb., 60 ets. lb.

Sweetheart.-New.. Globular in shape; skin very bright, mottled green; flesh bright red, firm and heavy, but crisp, melting and exceedingry sweet. 10 ets. oz., 15 cts. 1/4 lb., 50 ets. $1 \mathrm{~b}$.

The Boss.-An early, productive and good shipping variety; oblong in shape, rind very dark green; flesh very deep searlet, melting and sugary. 10 ets. oz., 15 ets. 1/1 lb., 50 ets. 1b.

Triumph.-New. Nearly round, large, and an excellent shipper; skin dark green; flesh bright red. 10 ets. oz., 15 cts. $1 / 4$ lb., 5) cts. lb.

\section{MUSTARD}

\section{German, Senf.}

One ounce will sow 75 fect of drill.

CutruRe.-As an ingredient, the green Mustard imparts a delightfully pungent fla. ror to the various forms of prepared salads. 


\section{CHOICE GARDEN and FIELD SEEDS-Continued.}

For early crops the seed may be sown in a hotbed in March, and for general erop at frequent intervals throughout spring, in drills $\&$ to 12 inches apart.

Southern Giant Curled.-This is grown extensively in the south, where it is highly esteemed. Oz. 5 cts., $1 / 4$ lb. 15 cts., lb. 40 cts.

White London.-Considered the best for salads and spinach; leaves light green. It is best when about 4 inches hight. Oz. 5 cts., $1 / 4$ lb. 10 ets., lb. 25 ets.

\section{ONION SEED}

German, Zwiebel. Uein. Cebuia.

One ounce will plant 100 feet of drill; 5 or 6 pounds in drills for an acre. For sets from 50 to 60 pounds should be sown to the acre, according to the richness of the soil.

Culture.-The Onion thrives best in a rather deep, rich loamy soil, and, unlike most regetables, succeeds well when cultirated on the same ground for successive years. The best culture requires that the ground should be deeply trenched and manured the previous autumn, and laid up in

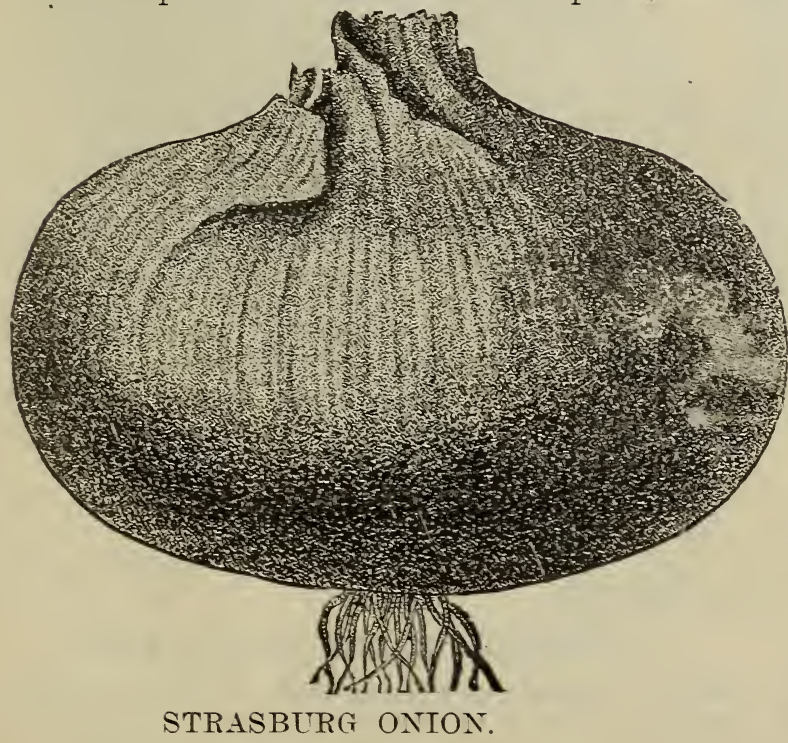

free from weeds by frequent hoeing, taking care not to stir the soil too deeply, or to collect it about the growing bulbs.

Prices in quantity on application.

Bermuda White.-White in color, but otherwise similar to Red Bermuda. Pkt. 5 ets., oz. 20 ets., 60 ets. $1 / 4$ lb., $\$ 2.00$ lb.

Large Red Wethersfield.-Onion-growers who prefer the red varieties will find our pedigree strain far surpassing the ordinary Red Tethersfield in size, productiveness and keeping qualities. It is of the finest form; skin deep purplish red, flesh purplish white, much finer grained than many of the red sorts. Inmense crop of this Onion are grown each season from our seeds by some of the largest growers in the United States, who realize the very highest prices for their crops. 15 ets. oz., 45 cts. $1 / 4$ lb., \$1.50 lb.

Philadelphia Yellow Dutch, or Strasburg. -The great set Onion-our pedigree seed. The most popular variety for sets, grown so extensively by market-gardeners around Philadelphia and elsewhere in the Union. The sets of this variety grow round, plump and bright. Full-sized Onions are somewhat flattened; flesh pure white, mild-flavored and an excellent keeper. Skin bright yellow. Oz. 15 cts., qt. 35 cts., 1 b. 90 cts.

Prizetaker.-This variety, of recent introduction, annually grows in faror. It excels every Onion now existing in beauty, size and productiveness, and equals the best in quality, being as mild in flaror as the imported Spanish Onions of our grocers. Oz. 15 cts., 1/4 lb 35 cts., 1b. $\$ 1.10$.

Southport Yellow Globe, Select. ed.-All grown from selected, hand-picked bulbs; none but those perfect in size and shape being set for seed. Oz. 20 ets., $1 / 4$ lb. 60 ets., lb. $\$ 2.00$.

White Portugal, or Silverskin. -A large, flat, white Onion of mild and pleasant flavor; hard and fine-grained, and a good keeper. Extensively sown for sets, and is also largely grown for pickling.

ridges during the winter to pulverize. As early in the spring as the ground is in working order. commence operations by leveling the ground with a rake and tread it firmly; sow thinly in drills about one-fourth of an inch deep, and 1 foot apart; cover with fine soil, and press down with the back of a spade or a light roller. When the - oung plants are strong enough, thin gradally so that ther stand 3 or 4 inches apart. eep the surface of the ground open and
Oz. 20 cts., $1 / 4$ lb. 60 cts., lb. $\$ 2.00$.
Yellow Globe Danvers, Our Finest Strain.-This is the product of years of careful selection, and is the most perfect type of the Yellow Globe Danvers Onion which intelligent, painstaking care can produce. It is immeasurably superior to tho average seed offered, not only in shape and color, but in productiveness. The product of this seed always finds a ready sale, even when the general crop is a "glut" on the 


\section{CHOICE GARDEN and FIELD SEEDS-Continued.}

market, and will always average 50 cents per barrel more than any other strain. This, our special strain, is all grown from selected seed. Oz. 15 cts., 1/4 lb. 35 cts., lb. \$1.00.

\section{OKRA}

German, Ocher. Gombo. Quimbombo. One ounce will plant 100 hills.

This is an annual ofrom the West Indies, cultivated for its green seed pocis, which are used in soups or stewed and served like asparagus. It is highly esteemed in the South for making gumbo soup. The pods when young and tender should be sliced in sections, strung on a thread and hung up in the shade to cure like dried apples; can be used for soup at any time.

Culture.- Sow the seed thinly in dry, warm soil, in shallow drills 2 feet apart. After the plants are up, thin them out to 9 inches apart; hoe frequently, and draw a little earth to the stems as they grow. Gather the pods when quite green and about $11 / 2$ inches long.

Extra-Early Dwarf.-(Green pods.) Very early and productive. Pkt. 5 cts., oz. 10 cts. 20 cts. $1 / 4$ lb., 50 cts. lb.

\section{PARSLEY}

German, Petersilie. Prezzemolo. Peitroszka. One ounce for 150 feet of drill.

Culture.-Parsley succeeds best in rich, mellow soil. As the seed germinates very slowly, it should be sown early in spring, previously soaking the seed for a few hours in tepid water. Sow thickly in rows a foot apart and half an inch deep. For winter use, protect in a frame or light cellar, or a few plants may be placed in pots or boxes and kept in the house.

Champion Moss Curled.-An English strain with moss curled foliage and a very vigorous grower. A standard variety; desirable. $10 \mathrm{cts}$. oz., 15 cts. $1 / 4$ lb., 40 cts. lb.

Plain.-Leaves plain and dark-colored; very early and therefore popular. 10 cts. oz., 15 cts. 1/4 lb., 35 cts. lb.

Fine Double Curled.-A standard variety; plants bear an abundance of finely curled leaves; ornamental. 10 cts. oz., 15 cts. $1 / 4$ lb., 45 cts. $1 \mathrm{~b}$.

Triple Curled. -10 cts. oz., 15 cts. $1 / 4$ lb., 45 cts. $1 \mathrm{~b}$.

\section{PARSNIPS}

German, Pastinake. Panais. Pastinaca. One ounce per 200 feet of drill; 5 to 6 pounds in drills for an acre.

CuLture.- Sow as early in spring as the weather will admit, in drills 15 inches apart, covering half an inch deep. When well up, thin out to 5 or 6 inches apart in the rows. Unlike carrots, they are improved by frost, and it is usual to take up in fall a certain quantity for winter use, leaving the rest in the ground till spring, to be dug as required.

Prices on all varieties as follows: Pkt. 5 ets., oz. 10 ets., 1/4 lb. 15 cts., lb. 40 cts. Prices in quantity on applicalion.

Large Sugar, or Hollow Crown.-A reliable and favorite sort for general culture.

Smooth White.-A standard variety, with long, smooth white roots.

\section{PEAS}

German, Erbsen. Pisello. Groch. One quart for 75 feet of drill; 2 to 3 bushels in drills for an acre.

Culture.-Our trial of Peas is probably the most extensive on this side of the Atlantic, and it enables us to discard inferior sorts and to offer in the following list only the best varieties. Peas come earliest to maturity in light, rich soil. For general crop, a deep loam or a soil strongly inclining to clay is best. For early crops, decomposed leaves or leaf-mold should be used; or, if the soil is very poor, strong manure may be used. For general crops a good dressing should be applied, and for the dwarf-growing kinds the soil can hardly be too rich. When grown as a market crop, Peas are never staked; for private use, they are generally sown in double rows, and the tall varieties staked up by brush. For an early crop, sow as soon as the ground can be worked, and make repeated sowings every two weeks for succession. After the first of June sowing should be discontinued until the middle of August, when a good crop may sometimes be secured by sowing an extra-early sort for fall use.

If sent by mail, add 8 cts. per pt., 10 cts per qt., extra.

All marked thus $\left(^{*}\right)$ are wrinkled varıeties.

\section{EXTRA-EARLY DWARF PEAS.}

*McLean's Little Gem.-Very early; pro lific and of delicious flavor. Height, $1 \frac{1}{2}$ ft. 35 cts. qt., \$1.25 4 qts., \$2.25 pk.

*Extra-Early Premium Gem.-An improvement on Little Gem. Height, $11 / 2 \mathrm{ft}$. 35 cts., qt., 4 qts. $\$ 1.25$, pk. $\$ 2.25$.

*Nott's Excelsior.-Very early; pods always well-filled with peas of the finest quality. Height $11 / 1 \mathrm{ft}$. 30 cts. qt., $4 \mathrm{qts}$. $\$ 1.10$, $\$ 2.00 \mathrm{pk}$.

Sutton's Excelsior.-New. As early as American Wonder, with much larger pods, and more prolific. Height, $1 \mathrm{ft} .40 \mathrm{cts}$. qi., 4 qts. $\$ 1.25$, pk. $\$ 2.25$. 


\section{CHOICE GARDEN and FIELD SEEDS-Continued.}

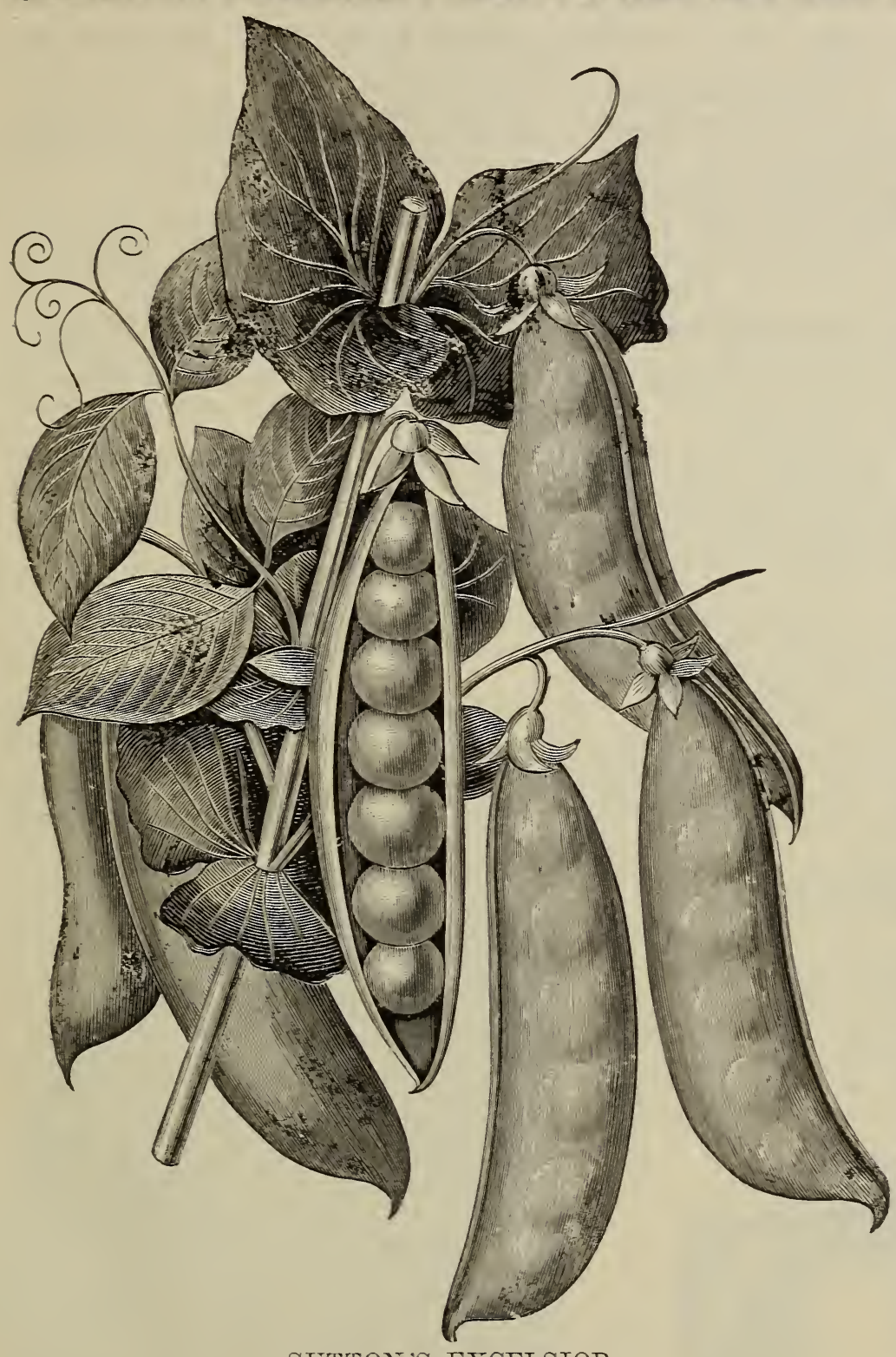

First and Best. - Very early and prolific; a stand. ard variety. Popular with canners. Height, $2 \frac{1}{2}$ ft. 30 cts. qt., 4 qts. $\$ 1.00$, pk. $\$ 1.75$.

*G r a d us, or Prosperity-With. out doubt the fin. e st extra - early Pea ret introduced; it is in condition to $\mathrm{pick}$ about four days after Rice's Ex. tra Early. The pods are very large, and well filled with large, wrinkled, de e $\theta$ p green peas of the verr finest quality. Height, 3 ft. 45 ets. qt., 4 qts. $\$ 1.60$, pk. $\$ 3.00$.

Improved Dani e 1 O'Rourke.One of the best early Peas. Height, $21 / 2$ ft. 25 cts. qt., 4 qts. 90 ets., pk. $\$ 1.75$.

*Thomas I a $\mathbf{x}$. to n.-Similar to Gradus, but more hards and produc. tire. Height. $3 \mathrm{ft}$. 40 cts. qt., 4 qts. $\$ 1.50$, pk. \$2.75.

SECOND- EARLY PEAS.

Prices as fol. lows, except where otherwise noted: Pkt. 5 cts.. pt. 20 cts., qt. 35 ets. Prices in quantity on application.

A lderm a n.-
EXTRA-EARLY PEAS (Not Dwarf).

Prices as follows, except where otherwise noted: Pkt. 5 cts., pt. 15 cts., qt. 25 cts., $1 / \pm$ bus. $\$ 1.25$.

Alaska.-The earliest blue Pea; a fine sort; popular with canners and marketgardeners; ripens uniformls. Height $21 \% \mathrm{ft}$. 30 cts. qt., 4 qts. $\$ 1.00$, pk. $\$ 1.75$.

Eclipse.-(Gregory's Surprise). New. Terr early and of excellent qualitr. Height, 2 ft. 30 cts. qt., 4 qts. $\$ 1.00$, pk. $\$ 1.75$.
Nen: Extra-large, dark green pods on order of Duke of Albany; verr fine. Height, 4 ft. 35 cts. qt., 4 qts. $\$ 1.20$, pk. $\$ 2.25$.

*Bliss' Everbearing.-Continuous bearer; pods long; delicious flaror. Height. 2 ft. 35 cts. qt., 4 qts. $\$ 1.25$.

Telephone.-Pods rers large, filled with immense peas of first-class quality; one of the rery finest ret introduced. Height, $11 / 2$ ft. 40 cts. qt., 4 qts. \$1.25, pk. \$2.25.

*Dwarf Telephone (Carter's Daisy). Excellent new rariety; large, well-filled pods; 


\section{CHOICE GARDEN and FIELD SEEDS-Continued.}

peas of fine flavor. Height, $11 / 2 \mathrm{ft} .45 \mathrm{cts}$. qt., 4 qts. $\$ 1.50$, pk. $\$ 2.75$.

*Yorkshire Hero.-A splendid, large marrow Pea; abundant bearer; fine quality; always a favorite. Height, $21 / 2 \mathrm{ft} .35 \mathrm{cts}$. qt., 4 qts. $\$ 1.20$, pk. $\$ 2.25$.

*McLean's Advancer.-Of excellent quality; popular with market-men and canners. Height, $21 / 2$ ft. 30 ets. qt., \$1.10 4 qts., $\$ 2.00 \mathrm{pk}$.

\section{LATE PEAS FOR GENERAL CROP.}

Prices as follows, except where otherwise noted: Pkt. 5 cts., pt. 20 cts., qt. 35 cts. Prices in quantity on application.

Canada Field.-Seed small, white; for field culture only; largely used for sowing among oats. Height, $3 \mathrm{ft}$. Market price.

*Champion of England.-One of the richest and best. 30 cts. qt., 4 qts. $\$ 1.00$, pk. $\$ 1.75$.

*Sharp's Queen.-One of the few really fine Peas; large pods; peas large, deep green, of delicious flavor; has no superior for family or market. Height, $2 \mathrm{ft}$. 35 cts. qt., 4 qts. $\$ 1.25$, pk. $\$ 2.25$.

Stratagem Improved.-Heavy cropper, of delicious flavor; large, handsome pods, we!l filled. Height, 2 ft. 35 cts. qt., 4 qts. $\$ 1.20$, pk. \$2.25.

\section{PEPPER}

German, Pfeffer. Peperone. Pieprz.

One ounce will produce 2,000 plants.

CUTURE.-Grown largely for pickles. Sow in hotbeds early in April, and transplant to the open ground when the weather is farorable. They should be planted in warm, mellow soil, in rows 18 inches apa:t.

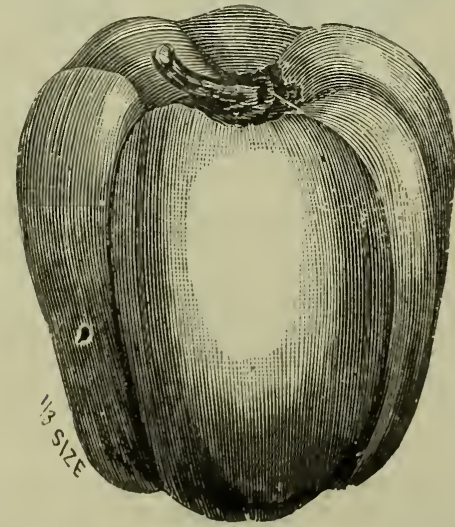

SWEET MOUNTAIN PEPPER.

They may also be sown in the open ground when danger of frost is past.
Chinese Giant.-New. The largest and finest mild red variety. 40 ets. oz., \$1.25 $1 / 4 \mathrm{lb} ., \$ 4.00 \mathrm{lb}$.

Large Bell, or Bull Nose.-A favorite and well-known pickling sort; is early, large, mild and thick-skinned. 20 cts. oz., 60 cts. $1 / 4 \mathrm{lb}$.

Long Red Narrow Cayenne.-Pods slender, about 3 inches long and bright red; very pungent and productive. 20 ets. oz., 60 cts. $1 / 4$ lb., $\$ 2.00 \mathrm{lb}$.

Ruby King.-The best and most profitable mild red Pepper for market or family use; so sweet and mild they can be eaten raw like an apple; large size. 20 cts oz., 60 cts. $1 / 4$ lb., $\$ 2.00 \mathrm{lb}$.

Sweet Mouniain, or Mammcth.-Large and mild-flavored; a well-known standard sort; color glossy red; rind thick and fleshy; popular with all growers for market. 20 ets: oz., 60 ets. $1 / 4$ lb., $\$ 2.00$ lb.

\section{POTATOES (For Seed)}

German, Kartoffeln. Pomme de Terrc. Batatas.

In drills 3 feet apart, 12 or 14 bushels to the acre. One peck will $\mathrm{p}$ ant about 125 hills.

Culture.-The Potato, like all robustgrowing regetables, can be grown with varying success on soils of all kinds and in all conditions of fertility, but the soil best suited to it is a sandy loam. In all heavy soils it is more subject to disease, and the flavor, also, is much inferior. In byaking up good pasture land, the decaying sod answers sufficiently well for the first year in lieu of manure. Manure is appled either in rows or hills, or broadeast over the yround and plowed in-the latter in mo:t cases being preferable. If the soil is gool, but little manure is required. In highly en riched soil the plants are more liable to disease than when grown in soil that is naturally good. The best fertilizers are those of a dry or absorbent nature. as plaster, lime, superphosphate of lime and bone dust. For wet soils these are particularly beneficial, as they not only promote growth, but prevent disease. Plant as early in spring as the ground can be had in fair working order, in hills or ridges about 3 feet apart, covering in light, warm soils about 4 inches deep, but in cold, wet situations $21 / 2$ or 3 inches will be sufficient.

Prices of all varieties of Potatoes on ap. plication.

EXTRA-EARLY POTATOES.

Early Ohio.-Now widely known and deservedly one of the most popular sorts. It has the advantage of being fit for use and sale even before fully ripe. A few days earlier than the Early Rose, and similar in 


\section{CHOICE GARDEN and FIELD SEEDS-Continued.}

color and habit of growth. Quality dry ani mealy.

Eariy Rose.-Our stock of this popular variety is in its original purity, we having renewed otir planting stock anntalıy ior several reais past irom Houlton, ilaine, where it is re.y popular and abost the oniy varicty planted $101^{\circ}$ market.

Iri $=$ Cobbler. - A variety which becomcs popular wherever tried on account of is earliness, handsome appearance and exce. lent quality. 'Tubers are round and smooti, skin creany white and often netted; flesis white. We do not hesitate t, recommen.l this varietr.

Holton Early Pucse.-Early, with quality and productireness.

State of Maine.-A standard winte Potato that has proven a very reliable one. Shape round to oblong, siightly flattenei, medium late and a good yielder.

\section{PUMPKIIN}

German IÏ̈rbis. Iucea. Bania.

One pound will plant from 200 to 300 hill .

CuLTCRE.-The eommon practes is to drop two or three see $\mathrm{s}$ in erary thir cr.

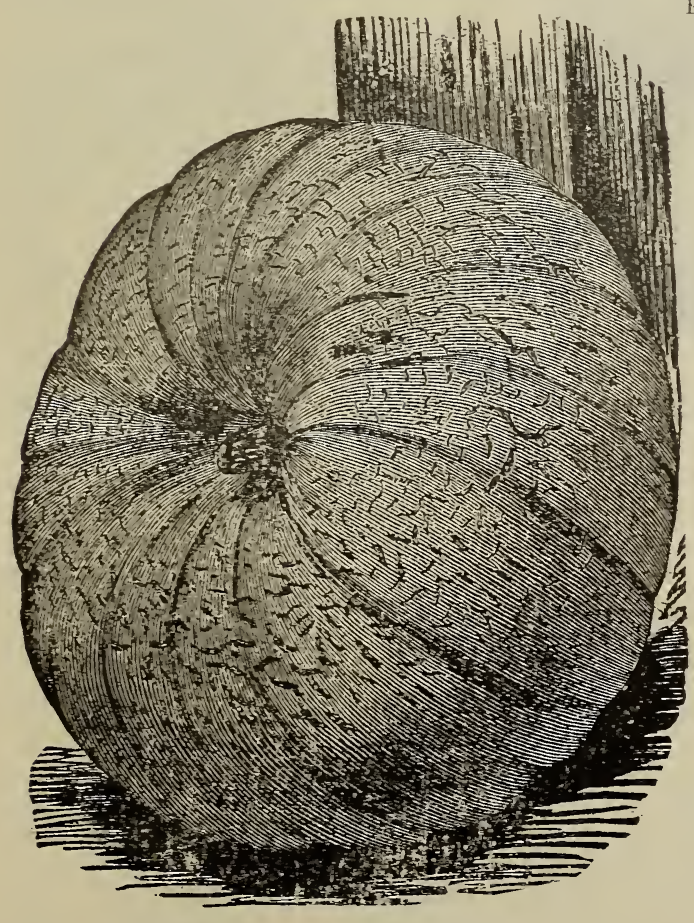

KING OF MAMMOTHS.

fourth hill in the cornfield, but if cult $\mathrm{rat}$ d on a large scale the seol may be sorn in hills 8 feet apart each way, four plants to each hill, and otherwise treated in the same manner as recommended for melons or cu. cuimbers.

Prices in quantity on application.

Connecticut Field. - This variety is most extensively used throughout New England and New York for field culture; is generally planted with corn. 5 ets. oz., 10 cts. 1/4 ib., 25 cts. $1 \mathrm{~b}$.

Large Cheese, or Kentucky Field.-Flat and round like a cheese; color of skin deep orange, flesh somewhat liginter; one of the best for table use. $10 \mathrm{c}$. oz., 15c. 1/4 lb., 50c. $1 \vdots$.

Fing of Mammoths.-This is truly a giant among Pumpkins: specimens hare been grown to weigh 250 pounds. In shape it is round flat and slightly ribbed; color of skin and flesh bright golden yellow and of good quality, making excellent pies, but grown principally for stock; keeps well. 10 ets. oz., 20 ets. $1 / t$ lb., 60 ets. lb.

Livingston's Cushaw.-Mottled green and white striped; flesh yellow, solid and fine-grained. 10 cts. oz. 15 cts. $1 / 4$ lb., 50 ets. lb.

Tennessee Sweet Potato.-One of the rery hest for cooking purposes. Nearly pear-shaped, with neck slightly crooked;

skin and flesh creamy white, slightly striped with green, fine-grained and of excellent flavor; hardr and rers proluctire. 10c. oz., 20c. 1/4 lb., 60c. lb.

\section{RADISH}

Gerizan, Fittia, Radies. Ravenollo. Rzodkiev.

One ounce will sow 100 feat of drill.

('ULTURE.-The soil for Radishes should he rerv rich, light and mellow, we!l broken br digging, as their tender and mild qualities depend much upon their rapid growth. For vers early use, sow in gentle hotbeds in February, and in the open air as soon as the ground can be worked, at intervals of ten or trelve days for a succession as long as they may be wanted. The winter rarieties should be somn in August, lifted before serere frost, and stored in the cellar.

Turnip, Extra-Early Scarlet Whitetipped Forcing.-A beautiful forcing variety; similar in shape and appearance to Scarlet Turnip Thite-tipped. Has small top and may be planted closely. 10 cts. $0 z . .20$ cts. $1 / 4$ lb. 50 cts. lb.

Turnip, Philadelphia White Box.One of the best rarieties for growing nnder glass, as well as for outdoor culture; it is a rapid grower, with a short top; a beautiful round white varietr; grows to a good size, and is alwars crisp, fine- 


\section{CHOICE GARDEN and FIELD SEEDS-Continued.}

grained and tender. 10 ets. oz., 20 ets. 1/4 Long Chartier, or Shepard.-A very lb., 50 cts. $\mathrm{lb}$.

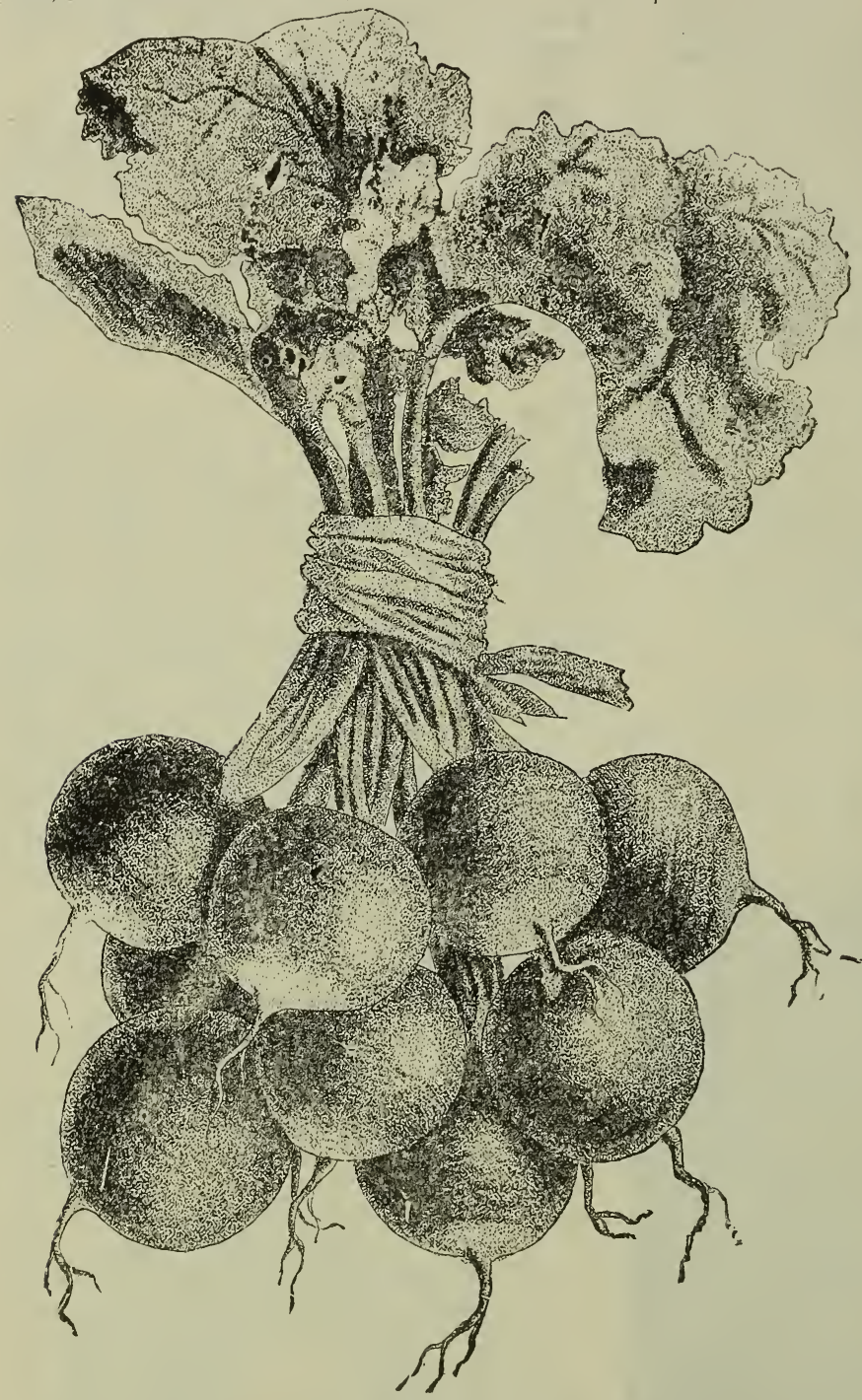

crisp, and does not become pitlyy or hollow for a long time after attaining its full growth. Its shape is long, being of a cieep crimson at the top and shading off to white at the bottom. $10 \mathrm{cts}$. oz., 20 cts. $1 / 4$ lb. 50 cts. lb.

Long Icicle.- The finest white variety. Tery early. 10) cts. oz., 20 ets. $1 / t \mathrm{lb}$, 6) (cts.. lh.

Long Scarlet. 10 cts. uz., 20 cts. $1 / 4$ lb., 50 ets. lb.

Long White Vienna.Practically the same as I ady-Finger. 10 ets. oz., 25 ets. $1 / 4$ lb., 45 ets. lb.

White Strasburg.-O n e of the best of the long summer sorts; roots are long, liandrome and tapering. and both skin and flesh pure white, flesh firm, brittle, tender. 10 ets. oz., 20 cts. $1 / 4$ lb., 50 ets. lb.

\section{FALL, or WINTER}

\section{RADISHES.}

Long Black Spanish.-A long, black-skinned variety; flesh white and slightly pungert; one of the latest and hardiest. 10 cts. oz., 20 cts. $1 / t$ lb., 45 cts. lb.

Rose China Winter.Bright rose-colored skin; flesh white and quality excellent; one of the best for fall and winter use; a favorite with market-men. 10 ets. oz., 20 cts. $1 / 4$ lb., 50 ets. lb.

White Chinese, or New Celestial.-It is ready for use when $21 \frac{2}{2}$ or 3 inches long, and continues until nearly 6 inches long. making it an all season radish. The flesh is firm, solid and pure

Early Scarlet Prussian Globe.-Valuable for forcing. $10 \mathrm{cts}$. oz., 20 ets. $1 / 4 \mathrm{lb}, 6$ ? cts. 1 b.

Olive-Shaped, French Breakfast.-Pink color, olive shape, white-tipped, and the favorite variety in the markets of Paris; pop. ular everywhere. 10 cts. oz., 15 ets. 1/t lb., 40 ets. 1h.

Long Cincinnati Market.-An improrel strain of th well-known Long Scarlet Short Top. An excellent variety. 10 ets. oz. 20 ets. $1 / 1$ lb., t5 ets. $1 \mathrm{~b}$. whitc, and is rery attractive in appearance. 10 cts. oz., 20 ets. 1 it lb., 60 ets. lb.

\section{RHUBARB PLANTS IN SEASON. \\ RAPE, DWARF ESSEX FOR SOWING.}

A more general use of this seed would move of great alvantage to farmers, for it not only mak's exeellent pasture, but thore is no p'ant that will give as large a 


\section{CHOICE GARDEN and FIELD SEEDS-Continued.}

yield of foliage at so small an expense as this.

For green manuring or for exhausted soils it has no equal, and no pasture can be provided on which sheep will thrive better.

Care should be taken, however, to secure the genuine Dwarf Essex and not the annual variety, which is not only worthless for feeding, but is liable to become an obnoxious weed.

CULTuRE.-Prepare the ground as for turnips and sow in June or July, with a tur. nip drill, in rows $21 / 2$ feet apart at the rate of $21 \underline{2}$ pounds of seed per acre. It may be sown broadcast at the rate of 5 pounds per acre. Prices on application.

\section{SALSIFY, OR OYSTER PLANT}

German, Bobskart, Sassefricu. Jarzynoua. One ounce will sow 50 feet of drill.

Culture.-Sow the seed in light, deep soil, early in spring, in drills 12 inches apart and 1 inch deep, thinning out the roung plants to 4 or 5 inches. The roots will be ready for use in October, when a supply should be taken up and stored like carrots. Those remaining will suffer no injury by being left in the ground till spring, but should be dug up before commencing their growth.

Mammoth Sandwich Island.-We consider this the largest and most profitable Salsify in cultivation; roots are two to three times the size of the ordinary Salsify, and of more agreeable flavor. It is pure white in color, and invaluable to market-gardeners. 10 cts. oz., 35 cts. 1/t lb., $\$ 1.00 \mathrm{lb}$.

\section{SUNFLOWER}

Persons wishing to purchase in quantity will please write for special prices.

Mammoth Russian.-The standard largegrowing rariety, which is used largely for feeding poultry. 10 cts. $1 \mathrm{~b}$.

\section{SPINACH}

German, Spinat. Espinard. Espinaca.

One ounce for 100 feet of drill; 10 to 12 pounds in drills for an acre.

Culture.-This is a rery important crop in our market-gardens, and is one of the most easily managed of all vegetables, requiring but little culture, and may be had fit for use the entire season. The main crop is somn in September. It is sometimes covered up in exposed places with straw or salt hay during winter, which prevents it from being cut by frost; but in sheltered fields there is no necessity for covering. For sunimer use it may be sown at intervals of two or three weeks from April to August.
Spinach is best developed and most tender and succulent when grown in rich soil.

Prices on all varieties as follows: Pkt. 5, cts., oz. 10 ets. Prices in quantity on application.

Bloomsdale Savoy-leaved.-A heary cropper, of fine quality and very hardy; succu-

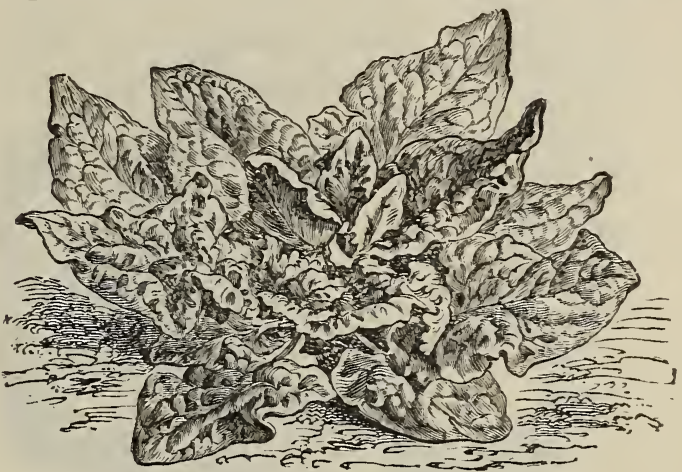

BLOOMSDALE SAVOY SPINACH.

lent leares, curled and crinkled like a Saroy cabbage; hardiest and most productire sort. 5 cts. oz., 10 cts. $1 / 4$ lb., 25 cts. $1 b$.

Prickly, or Winter.-Very vigorous and hards. 5 ets. oz., 10 cts. $1 / 4$ lb., 15 ets. $1 \mathrm{~b}$.

\section{TOBACCO SEED}

One ounce will som 25 feet square, and produce plants for one acre.

Culture.-Seeds may be started in hotbeds, or sown in the open ground as sooir as the ground can be worked, in rich dry soil; rake off the bed, and sow broadcast, pressing down firmly and eveniy, corering the seed very slightly; keep free from weeds, and water frequently if the weather is dry; set out the first of June, 3 feet apart, in land that has been heavily manured.

Fine Havana.-Finest strain of imported seed. Pkt. 5 cts., oz. 40 ets.

\section{SQUASH}

German, Kurbisz. Zucca. Miekuzr.

One ounce Early will plant 50 hills; 1 ounce Marrow, 25 hills.

Culture.-The plants are rery tender and sensitive to cold, and planting must be delayed until settled. warm weather. The general principles of culture are the same as those given for cucumbers and melons, but the plants are less particular as to soil. The summer varieties should be planted 4 feet apart each war, and the winter sorts 8 feet. Three plants are sufficient for a hill. Care should be taken not to break the stem, 


\section{CHOICE GARDEN and FIELD SEEDS-Continued.}

from the Squashes intencled for winter use, as the slightest injury will increase the liability to decay.

Prices in quantity on application.

Mammoth White Bush Scalloped.-Similar to Early White Bush, except that it is

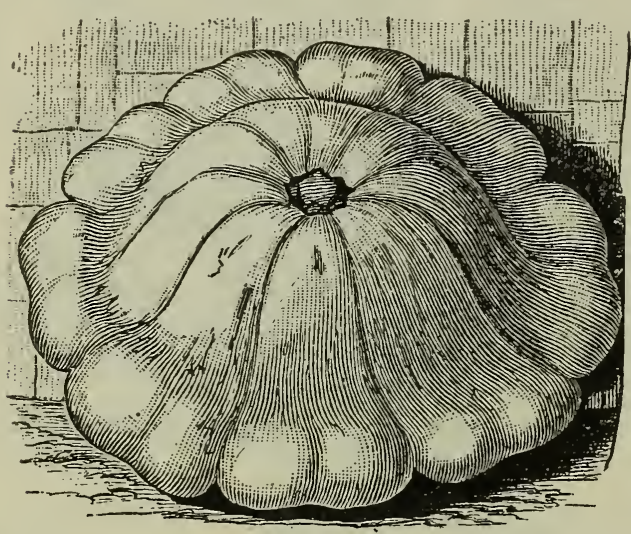

MAMMOTH WHITE BUSH SQUASH.

much larger. 10 cts. oz., 20 cts. $1 / 4$ lb., 60 cts. $1 \mathrm{~b}$.

Giant Summer Crookneck.-Double the size of the ordinary Crookneck and rery warty, but similar in other respects. Their handsome appearance commands an extra price in the market. 10 cts. oz., 20 cts. $1 / 4$ 1b., 60 cts. lb.

Improved Hubba:d.-The well-known and standard late variety; our strain is excellent. 10 ets. oz., 20 cts. $1 / 4$ lb., 60 cts. lb.

Mammoth Yellow Bush. 10 cts. oz., 20 ets. $1 / 4$ lb., 60 ets. lb.

\section{TOMATO}

German, Liebesapfel. Pomo d'Ora. Pomidor. One ounce will produce 1,500 plants.

('UlTuRE.-The Tomato is raised from seed, which should be sown in the hotbed about February 20, and continuous sowings made until April 1, according as the plants are wanted for use. When the plants are about 2 inches high, transplant to 4 inches apart; and, after three or four weeks, transplant from the hotbed into a cold-frame, setting the plants 8 inches apart each way. (A cold-frame is simply a low wooden frame corered with glass, ised to protect such plants as are not sufficinetly hardy to with stand our winters.) Keep the plants cool, so as to make them stocky. Set out in the open ground about June 1 , in well-enrichea soil, setting the plants 5 feet apart eaen way.

Prices as follows, except where otherwise noted: Pkt. j cts., oz. 20 cts. Prices in quantity on application.

Dwarf Champion.-Distinct in foliage and habit of growth, being compact and up. right; fruit smooth, early and purplish red. 20 ets. oz., 70 ets. $1 / 4$ lb., $\$ 2.40$ lb.

Earliana.-New. Claimed to be the earliest; large, smooth, red; very prolific. 20 cts. oz., 75 cts. $1 / 4$ lb., $\$ 2.50 \mathrm{lb}$.

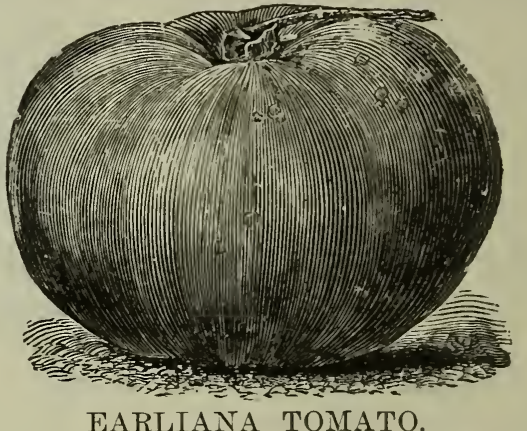

June Pink.-New. Very early ; of medium size, round, smooth and very solid.

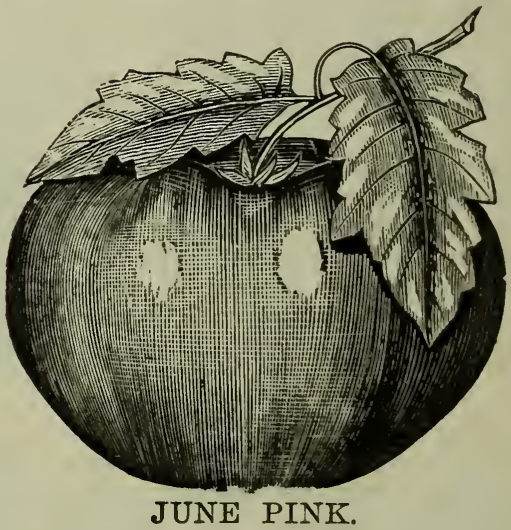

Color pink. 20 cts. $0 z ., 75$ ets. $1 / 4$ lb., $\$ 2.50$ $1 b$.

Livingston's Coreless.-New. A most

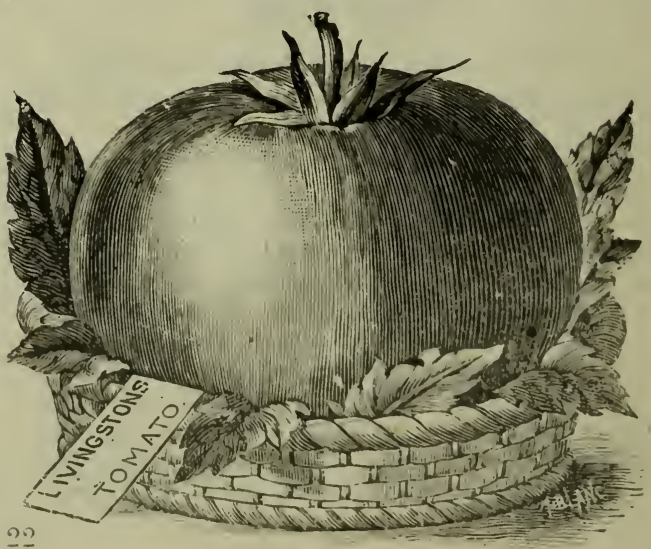




\section{CHOICE GARDEN and FIELD SEEDS-Continued.}

promising large, bright red, main crop, globe-shaped. 50 cts. oz., 90 ets. $1 / 4 \mathrm{lb}$.

Mikado, or Turner's Hybrid.-Very large, smooth and solid; skin purplish red. This is a pototo-leaved variety with few seeds. 20 cts. 0z., 70 cts. $1 / 4$ lb., $\$ 2.40 \mathrm{lb}$.

New Stone.-A great favorite with canners; the heaviest and most solid-fruited of the large Tomatoes of good quality. Our stock is distinctly superior to most of that offered under this name, being more uniform, better colored and larger. Fruit round, apple-shaped, rery large, deep red, and astonishingly heary. 15c. oz., 50c. $1 / 4$ lb., $\$ 1.75 \mathrm{lb}$.

Perfection. (Livingston's.) - A standard sort; early, regular and productive. A splendid spherical Tomato for canning or shipping; blood-red; has fer seeds. 15 cts. oz., 50 cts. $1 / 4$ lb., $\$ 1.50$ lb.

Yellow Plum.-Fruit plunı-shaped, deep yellow color; flesh yellow and good; esteemed for preserves. 25 cts. oz., 75 cts. $1 / \pm 1 b$.

Large Yellow Tomato.-A good eating tomato. 30 cts. oz., 90 cts. $1 / 4$ lb.

\section{TURNIP-Twenty-Four Sorts Short Crop}

Three ounces of seed will sow 100 yards of row. Four pounds to the acre. Matures for table in from 60 to 90 days, according to variety and season.

Turnip seed may be sown when the Peach is in bloom, or among the first seeds in early spring; indeed, the only hope of a succesful spring crop is in an early start, as otherwise the period of maturity extends into hot weather, when the bulb becomes fibrous and pungent. Midsummer and early Autumn are the seasons for successful Turnip drilling, though frequently the conditions of the soil then are not farorable to satisfactory vegetation.

The seed of Cattle Turnips is always drilled in rows, while the early-maturing and surface-rooted Table Turnip is generally sown broadcast. We advise the sowing, either in drills or broadcast, of not less that three pounds to the acre to insure a satisfactory stand.

The Bloomsdale Srede, like other RutaBagas, is slower in growth than the roughleared Turnips, but produces roots more solid and more nutritious-less laxative and more fattening. The Ruta-Baga is a gross feeder and will do best with 20 to 25 tons of stable manure to the acre; when it cannot be obtained apply 500 pounds of superphosphate.

Early Flat Red or Purple Top (Strapleaved), 60 days. - The oldest standard red. 30 cts. ]b., 10 cts. 1/t lb., 5 cts. pkt.
Cow-Horn (Large Cropper).-This variety is pure white, excepting a dash of green at the crown, and in shape is long like the Carrot. Lb. 35 cts., 1/4 lb. 15 cts., oz. 10 cts., pkt. 5 ets.

Bloomsdale Swede or Yellow Ruta-Baga (Maturing in 90 days). - The Bloomsdale is quite wonderful in its fine breeding. In noth.ng that we offer are the effects in selection and in careful breeding so apparent as in this Ruta-Baga. Lb. 40 cts., $1 / 4 \mathrm{lb}$. 15 ets., oz. 10 cts., pkt. 5 ets.

Golden Ball.-Roots medium size, quick in derelopment; always well shaped. Color golden, both in side and outside. Lb. 60 cts., 1/4 lb. 25 cts., oz. 10 cts., pkt. 5 cts. Amber Globe, Green Crowned, 75 Days. -This, which we introduced in 1863, is almost indispensable in erery rural househola.

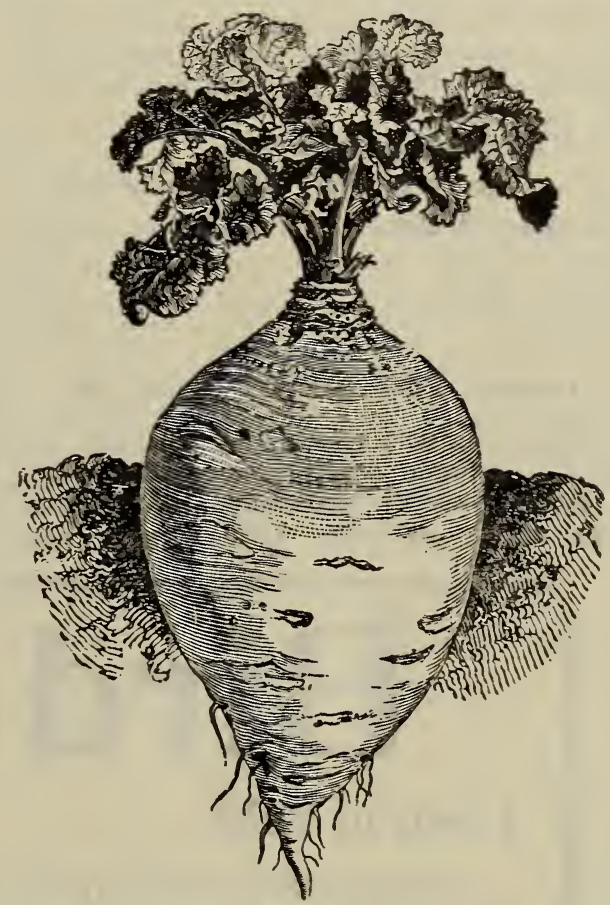

BLOOMSDALE SWEDE OR YELLOW RUTA-BAGA.

It is a vigorous, free grower, valuable for both table and cattle feeding. Productive and a good keeper. Lb. 40 cts., 1/4 lb. 15 cts., oz. 10 cts., pkt. 5 cts.

Large Early Red Top Globe, 65 days.Large size, rapid growth, unusually attractive and admired by all. A very much heavier producer than either of the preceding. Te confidently recommend it as an acquisition. Lb. 40 ets., $1 / 4$ lb. 15 cts., oz. 10 cts., pkt. 5 ets.

Yellow Aberdeen or Scotch Yellow.This is a highly approved Cattle Turnip. Lb. 50c., 1/4 1b. 20c., 0z. 10c.; pkt. 5c. 


\section{LAWN SEED.}

\section{SATTERTHWAITE'S T. \& S.} LAWN SEED

The first thing is to see that there is a good top soil of at least six inches. This should be graded and drained if necessary. The ground should be thoroughly mellowea by digging. Then it should be raked and rolled. All stones and roots should be removed. Now the seed may be sown. It should be lightly raked in and then rolleci. If the seed is sown in April and May it will make a good lawn by August.

\section{SATTERTHWAITE'S T. \& S. EVERGREEN LAWN SEED}

The seeds in this mixture are the best tested seeds obtainable. They are full of vitality and will secure a lawn quicker than any other seed.

Sow 5 bushels to an acre.

Sow 1 quart to every 200 square feet.

1 bushel, 32 lbs.............. \$5.50

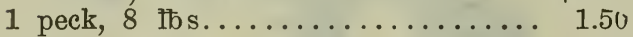

4 quarts, 4 tbs................ $\quad .85$

1 quart, 1 ib............... .25

\section{GRASS FOR SHADY PLACES.}

Satterthwaite's mixture of varieties produces a reliable stand under dense shade of either pine or hardwood trees in positions where all other Grasses may have failed. Eighty pounds should be sown to the acre-or say one pound on a space $20 \times 20$ feet, or in proportion for other dimensions.

Grass for Shady Places: Qt. 15r., Pk. $\$ 1.00$, bus. $\$ 3.25$, including postage.

\section{GRASS FOR GOLF LINKS}

\section{For the Course.}

This produces a soft, dense and uniform turf, except where influenced by soil con. ditions which are certain to vary somewhat on an extended course.

Popular-Lb. 40 cts., including postage. Bush., 20 lbs., $\$ 6.00 ; 100$ lbs., $\$ 25.00$.

Extra Special-Lb. 55 cts., including postage. Bush., 20 lbs., $\$ 9.00 ; 100$ Ibs. $\$ 40.00$.

\section{LAWN FERTILIZER}

Fertilizer for the Lawn-Per lb. 3c., per 100 lbs. $\$ 2.50$.

Ground Bone for the Lawn does not act as quick as fertilizer, but its power is shown longer. Per lb. 3c., per 100 lbs. \$2.50.

Satterthwaite's Special Evergreen Lawn Fertilizer.-This is a special fertilizer we prepare and is the best thing obtainable for lawns, plants and flowers. Per lb. 7c., 5-lb. pkg. 30c., 25-lb. pkg. \$1.00; 100-lb. pkg. $\$ 3.80$.

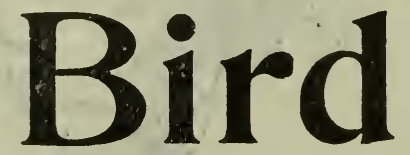

Fresh in Bulk.

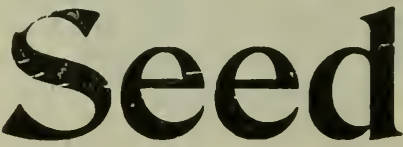

No Musty Packagé Seed.

The Siclly Canary Seed we sell is the real Sicily, a clean, bright seed. Our rape, the small black seed, is rape, not turnlp seed, and our hemp and sunflower is of the best.

Many bird fanciers are our customers, why not you?

Canary or Mixed Bird Seed, 15 c. a quart.

Buy by measure, and save money.

Bird gravel.

Cuttle fish bone.

\section{Satterthwaite's Seed Store}

\section{North Warren Street}

Opposito Trent Theatro.

Near all suburban trolley terminals. 


\section{GRASS SEED.}

All Prices.

on

Farm Seed

Vary.

Ask for

Market Price

When

Ready to

Buy.
Red Top. (Agrostis Vulgaris.) A valuable grass for moist soils and low lands. It is a good, permanent grass, standing our climate as well as any other, and consequently well suited to our pastures, in which it should be fed close. Fourteen-pound bushel.

\section{Solid Seed, Best Grade.}

Timothy.

(Phleum

Pratense.)-This is decidedly the best grass for hay, making a large return on strong, rich clay, of medium state of moisture.

Italian Rye Grass. (Lolium Italicum.) -A raluable European rariety, adapted to any climate, and produces large and nutritive crops. Eighteen-pound bushel.

Tall Meadow Oat Grass. (Avena Elator.) - This produces an abundant supply of foliage, and is valuable for pasturage on account of its early and luxuriant growth.

Hungarian Grass.

Kentucky Blue Grass. (Poa Praten- sis.) This is known in some sections as "Green Meadow, Grass", and "June Grass", but should not be confounded with "Poa Compressa," called by some "June, or Wire Grass.', It is the best pasture for our climate and soil, succeeding finely on hill lands and producing the most nourishing food for cattle, retains its qualities to a late period in winter,

All Prices.

on

Farm Seed

Vary.

Asik for

Market Price

When

Ready to

Buy. throughout the winter Sow early in the spring or during the months of October and Norember. Fancy clean seed.

Orchard Grass or Rough Cocksfoot. (Dactylis Glomorata.) This is one of the most valuable and widely known of all pasture grasses, coming earlier in the spring and remaining later in the autumn than any other. Blooms with red clover, making with it an admirable hay. It is well adapted for sowing under trees or orchards.

\section{CLOVER SEED.}

White Dutch (Trifolium Ripens. ) A small, creeping, spreading, perennial variety, valuable for pasture and lawns. In conjunction with Blue Grass it forms the most nutritious food for sheep or corrs.

Mammoth or Large Red. (Trifolium or Pratense.) It groms five or six feet high. By its judicious use lands which hare been exhaused may be reclaimed. Sow at the rate of about eight pounds per acre. Sixty pounds per bushel.

Alsike or Swedish. (Trifolium $H y$ bridum.) This raluable variety is fast gaining great popularity. It is the most hearty of all the clovers; perennial. On rich, moist soils it yields an enormous quantity of hay or pasture, and mar be eut sereral times in a season.
Alfalfa or Lucerne. (Medicago Sativa.) One of the best rarieties, succeeding in almost every situation and bearing heavo crops of forage. Will bear cutting three or four times during the season. For bringing up poor land it is the best of the clovers, as it not only produces large masses of foliage, but forces its roots down fully three feet into the earth. Sow early in spring to secure a good stand before winter, if to be used for pasturage or for curing.

Crimson or Scarlet Clover. It can be seeded at any time from June to October, at the rate of fifteen to twenty pounds per acre, and makes the earliest possible spring pasture, blooming the latter part of Apris or May, and for feeding as hay should be cut just before coming into full bloom.

Red Clover is the most used and best known. 


\section{MISCELLANEOUS GRAINS AND FORAGE PLANTS.}

\section{See Us About \\ SEED OATS. SEED WHEAT. SEED RYE.}

\section{SEED BUCKWHEAT.}

Japanese.-Grain very large. In color a dark brown. About a week earlier than Silver Hull. Very distinct.

\section{VETCHES.}

Sand, Winter or Hairy. (Vicia Villosa.) This variety thrives on poor, arid, sandy soils. It is sown either in fall or in spring, and generally mixed with rye, which serves as a support to the plants. It grows to a height of from three to four feet, and can be cut twice for fodder, first as soon as the bloom appears, and then it can be again cut for the seed. The plant is perfectly hardy, and the produce is recommended as most nutritious. The seed is black and per- fectly round, and should be sown at the rate of one and one-half bushels to the acre. Qt. 45 cts., bu. $\$ 10.00$.

\section{SUGAR CANE.}

\section{FIELD PEAS.}

Prices Subject to Change.

White Canada.-More used than any other.

Blue or Green.-Like above, except that color is a bluish green.

\section{COW PEAS-Black Clay. \\ DWARF ESSEX RAPE.}

The Best Sheep Feed in the World.

The true biennial variety. We are headquarters for this. Lb. 10 cts.., 100 lbs. $\$ 6.00$, 1,000 lbs. $\$ 55.00$.

\section{FLAP SEED. SUNFLOWER RUSS.}

\section{FLOWER SEEDS.}

\section{AGERATUM.}

The Ageratums are all very pretty, especially when grown in beds or borders. Of easy growth, flowers abundantly out-af-doors in summer and up until frost or in greenhouses in winter; therefore very desirable for bouquet-making. A bed with the centre of Salivia Splendens and border about 18 inches wide of blue Ageratum will make a dazzling sight for 90 days.

Dwarf Mixed.-Three colors. 18 inches. Pkt. 5 cts.

\section{ALYSSUM.}

Flowers from June to November, and all winter indoors. Is fragrant, makes a very pretty border, fine for carpet bedding, baskets, pot plants and in making small bouquets. Cut back when through flowering and will bloom again. Annual. Blooms for 60 days.

Maritimum (Sweet).-White ,8 to 12 inches. Pkt. 5 ets.

Sepatile Compactum.-Pkt. 5 ets.

\section{ASTERS.}

Clirysanthemum-like flowers surpassed by no plant in beauty. They vary in color from a delicate pink and white to deep red and purples. The plants thrive best in rich soil, but with suffieient moisture will give satisfaction in almost any garden plot, and blossom in profusion for 90 days or till late in the autumn, proving a constant delight even after other flowers have been killed by frost. They are especially adapted to house decora- tion, and when cut and placed in water hold the ${ }^{\prime}$ regal heads erect irom one to two weeks without withering. A bed of Asters in the garden or on the lawn is effective and beautiful for months, providing more cut fiowers than any other plants occupying the same space. Try Satterthwaite's Asters this year and see how unusually fine they are. 8 to 20 inches high according to variety.

Branching.- We cannot recommend the Branching too highly. It comes into flower a few weeks before Chrysanthemums and closely resembles small ones. The best Aster for cutting. White, lavender, pink, erimson, purple, mixed. 20 inches. Pkt. 10 cts.

Dwarf Varieties.-Mixed sorts in packet, 5 ets.

BACHELOR'S BUTTON.

Dwarf Mixed-Pkt. i) ets.

\section{BALSAMS OR LADY SLIPPER.}

Large flowered, full centered. A family of beautiful annuals with flowers as double as Roses, measuring from 2 to 2 1-2 inches in diameter. Bushes are of a strong, vigorous growth. Rich soil and deep culture is requisite to produce large and showy flowers. Seeds may be sown where they are wished, and later thin out the plants; but if started indoors they will flower earlier. Set plants about 2 feet apart, where they can havo plenty of sun. Our stock is exceptionally fine. Try it. In bloom for 60 days.

Tall Finest Mixed.-Pkt. 5 cts.

Balloon Vine.-Pkt. 5 cts. 


\section{FLOWER SEEDS-Continued.}

CANTERBURY BELLS.

See Campanula.

CARNATIONS.

See Dianthus, below.

COREOPSIS.

Finest Mixed.-Pkt. 5 cts.

COXCOMB CRESTATA NANA.

Pkt. 10 ets.

\section{COSMOS}

Every year this flower makes more friends. Both flowers and lace-like foliage are grand for cutting. Growing $t$ to 8 feet high from seed. In flower for 30 to 40 dars. See illustration. Valuable for screens.

Fine Mixed.-Only grows from 3 to 4 feet high, bearing white, crimson and pink flowers in July and onward. Pkt. 10 ets.

Mammoth Perfection.-Flowers of parfect form. great size and beauty. White, crimson, dark pink, white tinter rose. IFixed. Pkt. 10 cts.

\section{DAISY.}

Double Mixed.-Pkt. jo cts.

\section{DIANTHUS.}

In this family are the Pinks, Picotees and Carnations, which are surpassed by few garden flowers. These old farorites are still as popular as erer. Rich soil will make bright flowers. Most of the rarieties ars fragrant. In the open garden some bloom the first autumn; all bloom the second season. Nixed. Pkt. J cts.

\section{ESCHSCHOLTZIA.}

One of the most beartiful and showr of garden flowers. When grown in masses scarcely any plant produces a greater (iegree of splendor. Easily raised from seed. Sown in autumn the growth is of increased vigor. California State flower. Diameter of plant growth 20 inches. Blooming 6 ) dars.

Golden West.-Grand new variety havin: light canary-yellow flowers, with deep orange bloteh at base of each petal, forming a cross in centre. Flowers measure over 4 inches in diameter and have overlapping petals, delicately wared at edges. Pkt. 10 cts.

Mixed.-Various colors. 1 foot. Pkt. 5 ets.

Foxglove.-Finest Mixed. Pkt. 5 cts.

Gaillardia Grandiflora.-Pkt. 5 cis.

\section{GOURDS}

The Gourds are annuals, rapid growers, from 10 to 20 feet high, raluable for corering screens or arbors; should hare moist, rich loamy soil to attain perfection. The Bottle and Dipper Gourds are useful when dry for domestic purposes. The inside of the Luffa, Dish C'loth or Bonnet Gourd, is rery strong and gauze-like, and ean be utilized for many purposes.

Balsam Apple-Vine; 6 feet. Used as a lotion. Pkt. jots.

Balsam Pear.-Yine; 6 feet. Used as a lotion. Pkt. $\overline{5}$ cts.

Herciles' Club-C'limber; sometimes 8 feet long. Pkt. 5 ets.

Mixed Gourds.-Pkt. 5 ets.

\section{HELICHRYSUM.}

The Everlastings are annuals, and the most showr and attractive of all the Everlastings. Scarcely excelled as a garden ornament or a winter decoration.

Double Mixed.-18 inches. Pkt, 5 ets.

\section{HELIOTROPE.}

The Heliotrope is a sweet-scented tender perennial. Grows freely in the garden or greenhouse. Fine for bouquets.

Gian:s.-Newest large flowering varietics; mixed. Pkt. 10 cts.

\section{HOLLYHOCK.}

One of the grandest peremnials for a screen, throwing up spikes 4 or 5 feet high of beautiful flowers as double as a Rose. Nothing can be better for a background or to plant among shrubs. Blooms second rear.

Fine Double--Mjxed colors. The colors ace whte, red, crimson, yellow, and all shades of double flowers from nearly black to pure wh:te, representing the most beautiful combination when planted in groups. Perennial. Pkt. J cts.

Single IVixed.-Pkt. 5 ets.

\section{IPOMOEA. \\ (Morning Glories.) \\ JOHNNY-JUMP-UPS See Pansies.}

\section{LADY-SLIPPER.}

\section{LARKSPUR.}

\section{MARIGOLDS.}

Showr annuals of easy culture. The flowers of the African variety, in its perfection, are equal to the double Dahlia. The French, as double as a Ranunculus, in appearance and texture not unlike the richest relvet. Signata Pumila is of compact. globulous growth: the flowers, vellow and orange, corer the entire surface of the plant. In bloom for 90 dars.

Dwarf Brownie, or Legion of Honor.Plants about 9 inches high. Fine for borders or massing. Flowers brilliant gold with maroon blotching. in bloom from early summer till frost. Single. Pkt. 5 cts. 


\section{FLOWER SEEDS-Continued.}

Pkt. 5 ets.

\section{MORNING GLORY.}

\section{Pkt. 5 cts. \\ EVENING GLORY. \\ MIGNONETTE.}

No annual is a more general favorite than the Mignonette. Its modest, sweet- scenteci flowers recommend it to every one. One of of the easiest culture, it adapts itself to ali situations. Finds a place in the green house or conservatory, in a box or pot on the window, or in the open ground in summer. Blooms till fall. Sow seeds several times during season. In bloom for 60 days.

Golden Queen.-Fkt. $\overline{5}$ ets.

\section{NASTURTIUM.}

Dwarf.-Oz. 10 ets., $1 / 4$ lb. 30 cts., Ib. $\$ 1.00$.

Tall.-Oz. 10 ets., $1 / 4$ lb. 30 cts., lb. $\$ 1.00$.

\section{POPPY}

These old favorites have become very popular again, the new varieties adding greatly to their attractiveness. Every garı den should have a good supply of Poppies. They fit most anywhere and the perennial varieties remain for years. Bracteatum, Iceland and Orientale are perennials, tine otiers annuals. Sow seed in the open ground in the spring or fall. Will not bear transplanting. Most brilliant and showy flowers. I to 2 feet.

Carnation Mixed.-Pkt. j ets.

Nudicale.-Pkt. 5 cts.

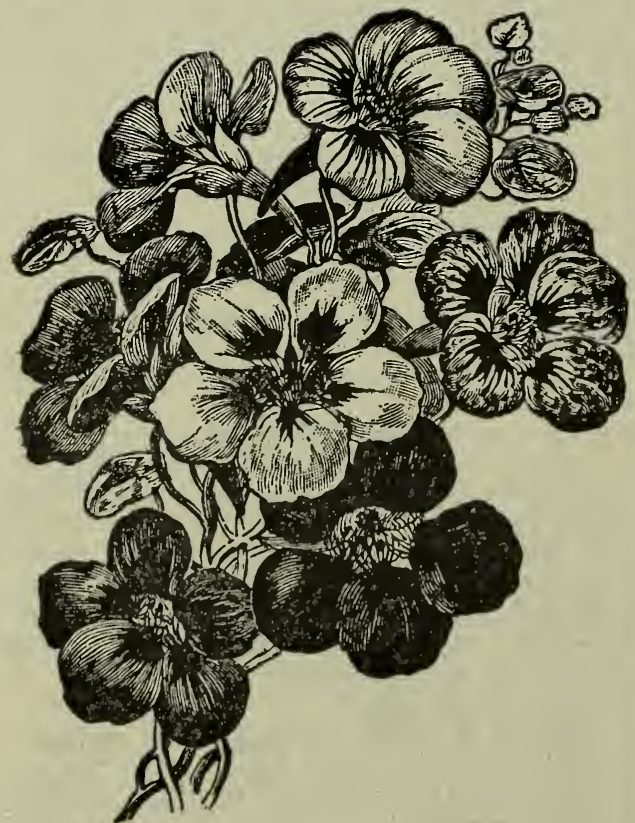

SUPERB COLLECTION OF NASTURTILMS.

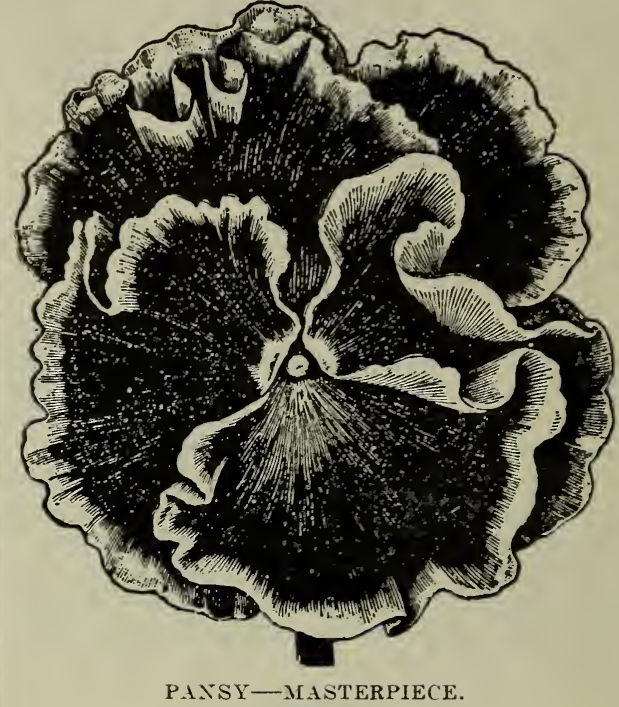

PANSIES.

Heart's-Ease._- 'Pansies for thoughts!', Have you ever thought how marvelously beautiful they are? Have you thought that no garden is complete without them? Have you thought Satterthwaite's Pansies the finest in the world? If not, try them this year and you will find them unsurpassed and of unusual size. 6 inches high, plants 8 inches in rliameter. See illustration.

Seeds should be sown out of doors very early in the spring or during August and the plants protected during winter. The happy faces of these flowers can but brighten every home. They are in bloom 60 dars after planting and continue to bloom till after frost.

Mixed, Finest Quality.-Pkt. $10 \mathrm{cts}$.

Mixed, Second Quality.-Pkt. 5 cts.

\section{PINKS-SeeDianthus.}

\section{PORTULACA.}

One of the most showy and beautiful of borker flowers. The seed germinates freely and flourishes in almo:t any situation. Does not grow over 3 to $t$ inches high, but spreads 2 fret wille. Any one can grow it in any garden. In the open they make a gorgeous berl, as they love the hot sun and a sandy soil: bloom for 60 dars. The double flowror resemble small roses.

Fines

Finest Mixed.-Resembles most beautifuI double rose. P'kt. 10 c.ts.

Petunia Mixed.-Pkt. j et:.

Double Mixed.-Pkt. 10 ets. 


\section{FLOWER SEEDS-Continued.}

\section{RICINUS.}

The Castor Bean, in all its varieties, has a showy tropical appearance, singly or in groups. Talmable for screens. See illustration.

Mixed.-Pkt. 5 ets.

\section{SALVIA.}

(Scarlet Sage.)-Half ounce should raise 1,000 plants. Half-hardy perennials. Sow seed in hotbed or box in house and plant out when ground is rarm, or sow out-doors latter part of May. In bloom 60 days. Must be taken up in the fall. 2 feet spread.

Bonfire.-A fine dwarf rariety, from w to 3 feet high; forms a dense, compact bush, is a heary bloomer. Brilliant scarlet. We especially recommend this sort of seed, which we grow every year on Bloomsdale to the extent of one to two acres. It is most brilliant and profuse in flowering. Pkt. 5 ets.

Blood Red.-A remarkable showy selec. tion from the Bonfire. Pkt. 5 cts.

\section{SNAP-DRAGON.-See Antirrhinum.}

\section{SUNFLOWER.}

Russian.-Pkt. 5 cts.

\section{SWEET WILLIAM.}

These flowers rere farorites in our grancfathers' gardens. Ther bloom early in the spring and continue in flower a long time. Plants are hardr and ther will bloom in August the first and second vear, and their number mar be increased by diriding the roots. Colors run from purple to white.

Double Mixed.-1 foot. Pkt. 5 cts.

Single Mixed.-1 foot. Pkt. 5 cts.

\section{TEN WEEKS' STOCK.}

Stocks are half-hardy annuals, beautifuI and fragrant. Sow under glass or on warm border early in spring, transplant to rich ground. See illustration.

\section{CUT AND COME AGAIN.} cts.

German Cut and Come Again. Pkt. j

Large Flowered.-Mixed. Pkt. 5 cts.

\section{THUNBERGIA.}

Handsome climbing greennouse perenniais, but will succeed in open ground as annuals if planted in a rarm sunny border; fine for basket, etc

Best Mixed.-5 feet. White and rellow. Pkt. 5 ets.

\section{VERBENA.}

The Verbenas are half-hardy perenniais. No flower garden is complete without Ver- bena. Mostly upright, but when prostrato taking root freely where stems come in contact with the ground. Grand for bedding. In bloom 90 days.

\section{WALLFLOWER.}

Is is great favorite. It is a half-hardy bIennial, producing beautiful fragrant fiowers. Requires protection during the Winter. Blooms second rear. 18 inches.

Large Flowering Double Mixed.-Plit ets.

Large Flowering Single Mixed.-2 feet.

\section{XERANTHEMUM.}

Hardy annuals, bearing florers in profusion. Much prize for Winter bouquets. Height 2 feet. The best varieties mixed. Pkt. 5 cts.

\section{ZINNIA.}

Double. Is an annual of robust habit, blooming from July to October. Seeds can be planted in the open, or young plants transplanted if desired. Drarf rarieties should stand about one foot apart, and tall rarieties double this distance. Will grow anywhere and stand any anount of rough treatment. In bloom 60 dars. Plants is inches spread.

Large Flowering Dwarf Mixed.-Pkt. 5 cts.

Large Flowering Tall Mixed.-All colors. 2 feet. Pkt. 5 ets.

Liliput.-Plants drarf and compact. Flowers small, perfectly double, pomponshaped, about size of large Daisy. Grand for pots, borders, or bedding. Mixed colors. Pkt. 10 ets.

\section{SWEET PEAS-The Beautiful and Popu- lar Flower of the Day}

CULTURE.-As early as the ground can be worked in the spring, make a trench 6 inches deep in rich soil. sor the seed in the bottom, corering not more than 2 inches deep; as the plants grow, fill in the earth around them and see that some suitable support is prorided for them to run upor. Flowers must be picked before pods form. othermise vines will not long continue to blossom.

Satterthmaite's headquarters for Sweet Peas.

Satterthwaite's Special Best Mixed.5 cts. oz., 10 cts. $1 / t$ lb., 40 cts. lb.

Spencer.-The new street pea. Mixed. 10 cts. oz., 20 cts. $1 / 4$ lb., 75 cts. $1 b$.

Separate colors as follows: 10 cts. oz., 15 cts. $1 / 4$ lb., 50 cts. $1 \mathrm{~b}$.

Nora Winivin.-Pure winie. iarge, wary open form.

Queen of Spain.-Soft buff pink. 


\section{FLOWER SEEDS-Continued.}

Bolton's Pink.-Rich salmon pink.

Mont Blanc.-Extra early, large, pure white.

American.-Bright blood red, striped.

Apple Blossom. - Pink and blush.

Black Night.-Deep maroon.

Blanch Ferry. - Extra earIy, pink and white.

Countess of Rednor--Lavender. Dorotny Eckford.-Pure white. Mrs Kenyon-Deep primrose.

Kath Tracy-Soft brilliant pink. King Edward VII.-Bright crimson.

Lady Grisel Hamilton-Pale lavender blue.

Lovely. - Deep rose-shading triple pink.

Modesty.-White tinted pink.

IMrs. Jos. Chamberlain-White striped pale rose.

Navy Blue-Finest of the blues.

Othello-Duf maroon.

Prima Donna.-Lovely soft pink. Queen Alexandria. - Bright scarlet red.

Royal Rose.-Fine deep rose color.

Salopian.-Brilliant scariet.

White Wonder.-Lovely pure white, often six to eight on long stout stems.

\section{BULBS FOR SPRING PLANTING.}

Plant as soon as the ground is mellow.

Pearl Tuberoses.-Per 100, $\$ 1.00$; per doz., 15 cts.

Caldium. -10 ets. each.

Cannas. - 10 cts. each.

- Madeira Vines. - 5 cts. each.

Gladiolus. -15 cts. doz.

\section{BULBS FOR FALL PLANTING.}

Roman Hyacinths-\$2.75 per 100,40 ets. doz.

Freesia (rep alba).-15 cts. doz.

Single Hyacinth-Mixed and separate colors. $\$ 2.50$ per 100,40 ets. doz.

Double Hyacinth-Mixed and separate colors. $\$ 2.50$ per 100,40 ets. cioz.

Single Tulips-Mixed. 90 cts. per 100, 20 cts. doz.

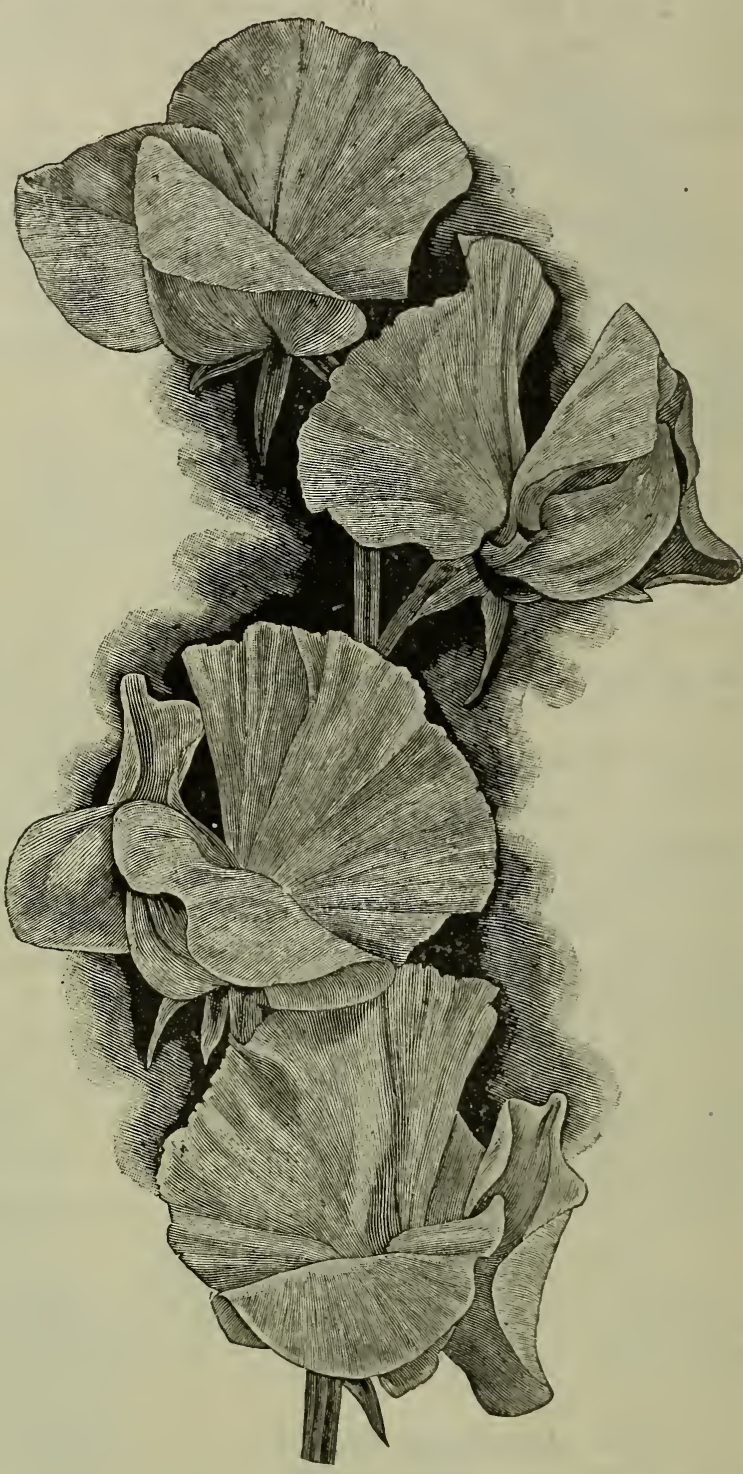

Double Tulips-Mixed. (10 '(t)s. per 100, 20 ets. doz.

Single Tulips, Cardinalshot-90 ets, per $100 ; 20$ ets. per doz.

S.ngle Tulips, L. Timacule-White. 20 ets. per doz.

Double Tulips, Maconsine.-20 cts. doz. Double Tulips, a la Manina-20 ets. doz. Double Nareinras, Mixed-15 cts. doz. Crccus, Mixed-12 cts. doz. 


\section{FARM and GARDEN SUPPLIES.}

\section{HEADQUARTERS FOR LAWN MOWERS.}

We carry only the Pennsylvania line. The best known, best made mower.

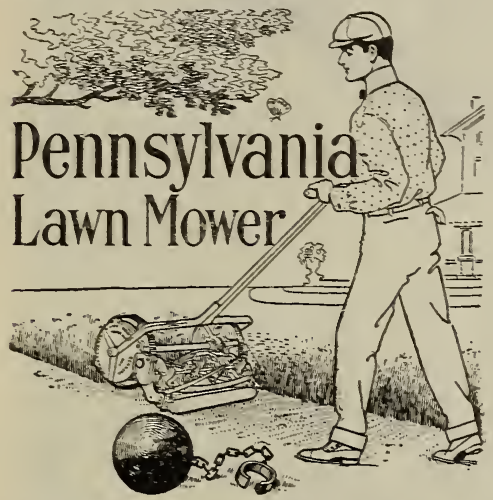

Buy a Pennsylvania Junior and Save Money and Work.

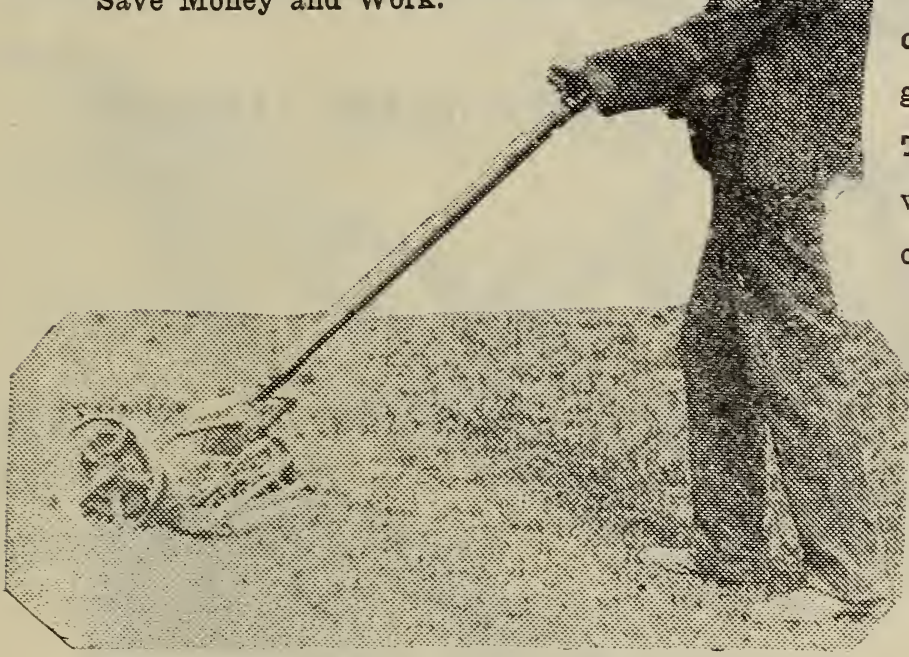
BEARING.

15 inches

17 inches

19 inches

The opposite picture is Charles Allen, gardener of the Widows' Home, Spring Street, and his Pennsylvania Junior Ball Bearing lawn mower, with which he cut 100 acres, measured ground the last 2 years. The first year the mowing was done without repairs or sharpening.

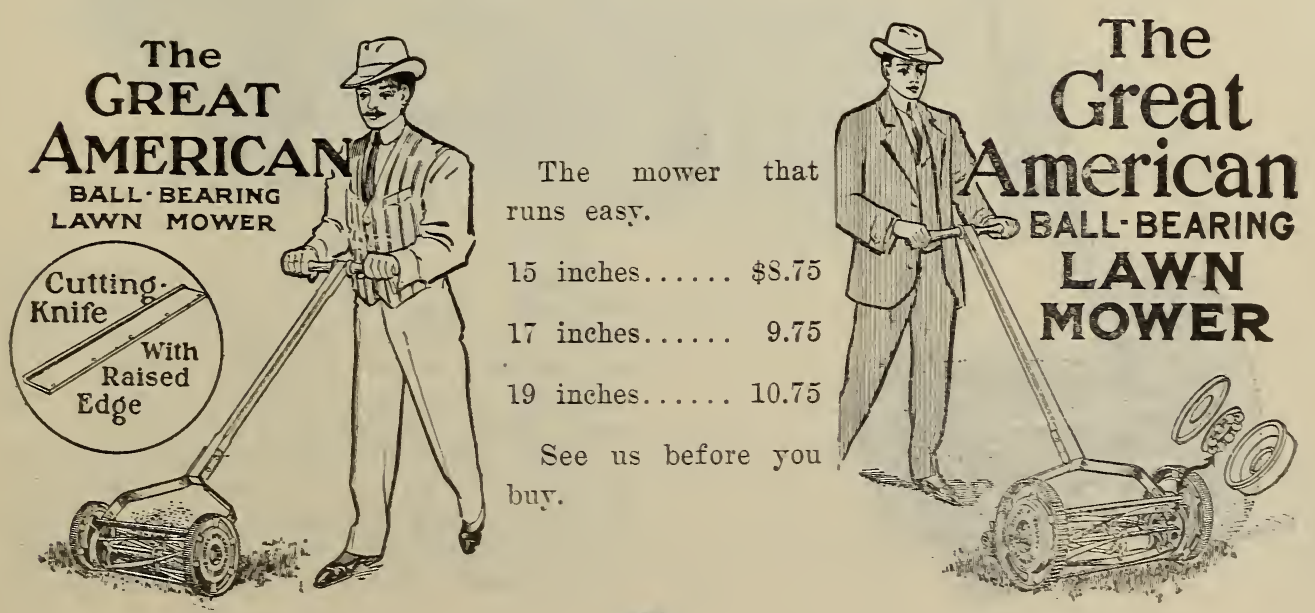




\section{FARM and GARDEN SUPPLIES-Continued.}

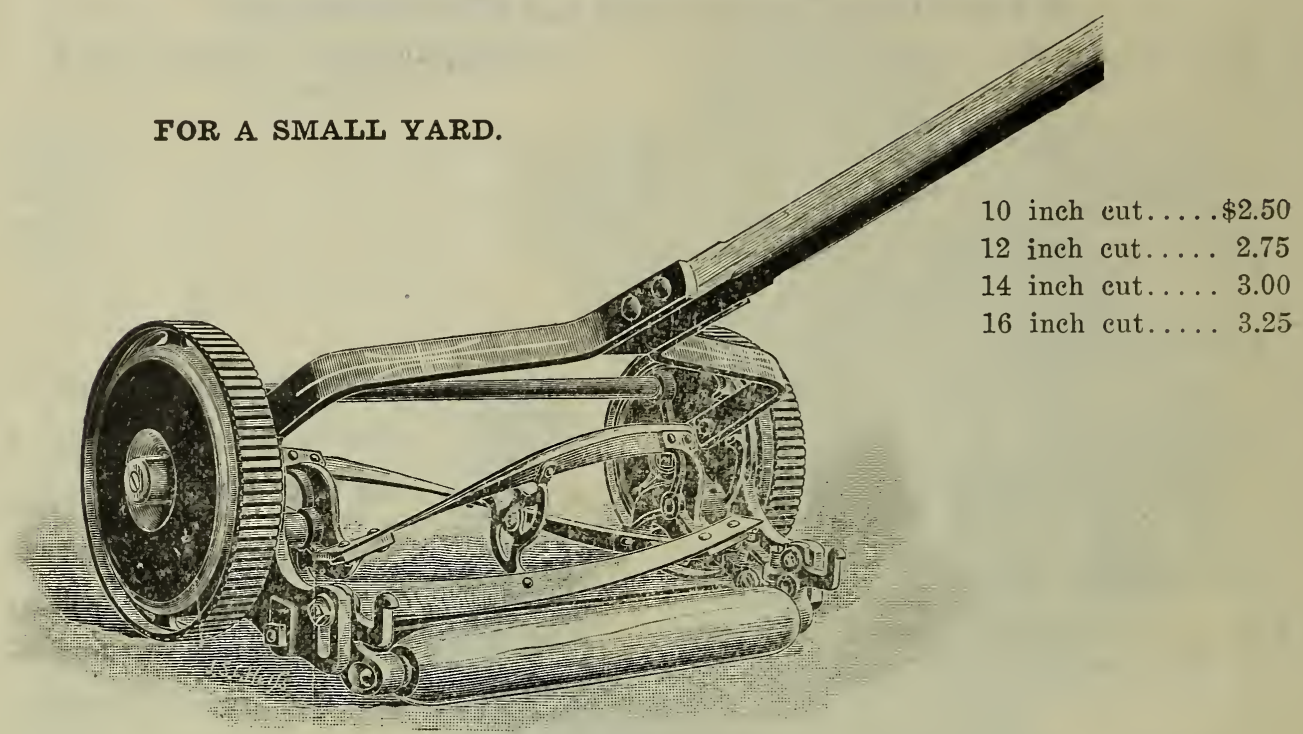

BRAWN GRASS CATCHERS.
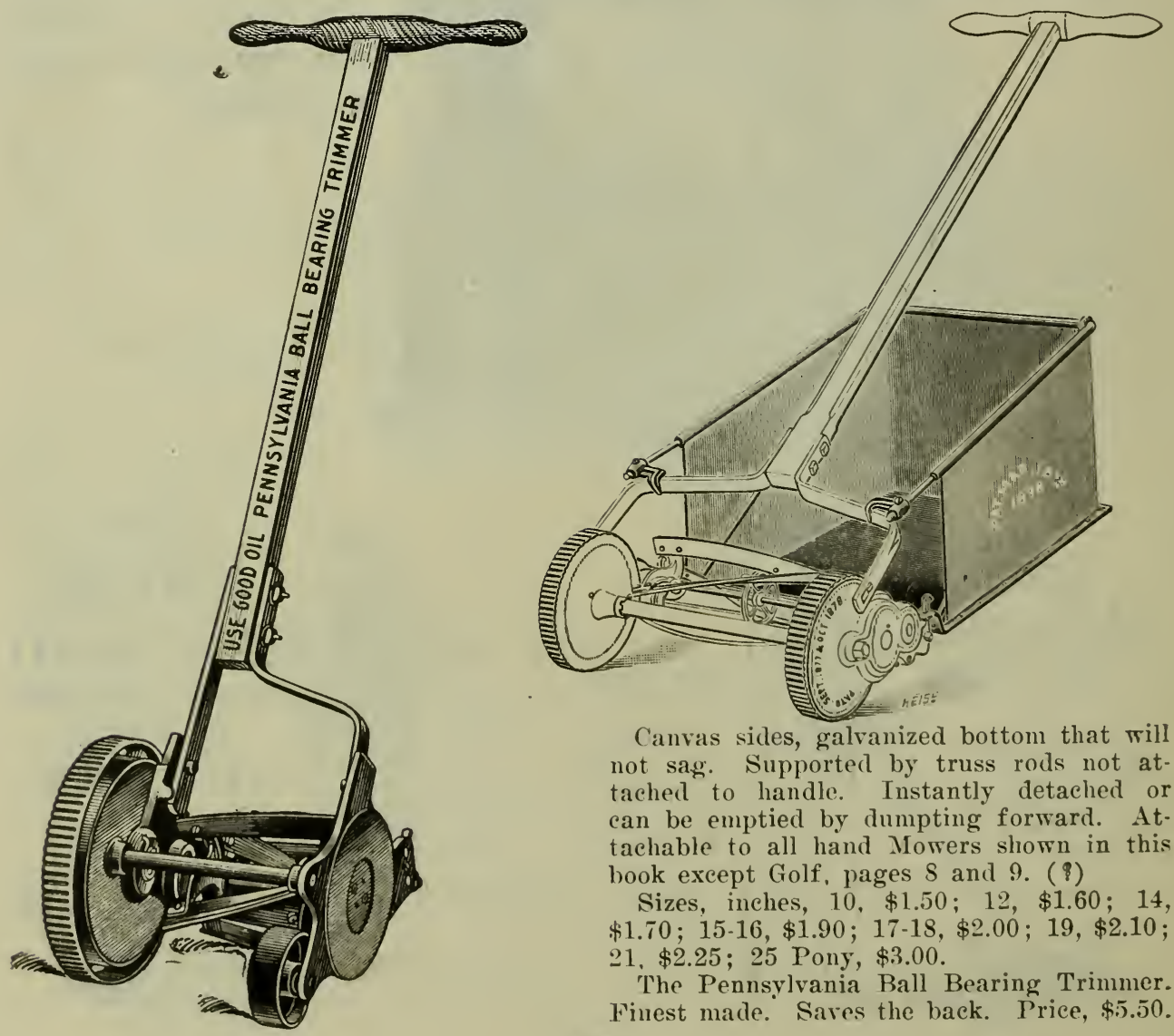

Canvas sides, galvanized bottom that will not sag. Supported by truss rods not attached to handle. Instantly detached or can be emptied by dumpting forward. Attachable to all hand Mowers shown in this book except Golf, pages $S$ and $9 .(8)$

Sizes, inches, $10, \$ 1.50 ; 12, \$ 1.60 ; 14$, $\$ 1.70 ; 15-16, \$ 1.90 ; 17-18, \$ 2.00 ; 19, \$ 2.10$; 21. \$2.25; 25 Pony, \$3.00.

The Pennsylvania Ball Bearing Trimmer. Finest made. Saves the back. Price, \$5.50. 


\section{FARM and GARDEN SUPPLIES-Continued.}

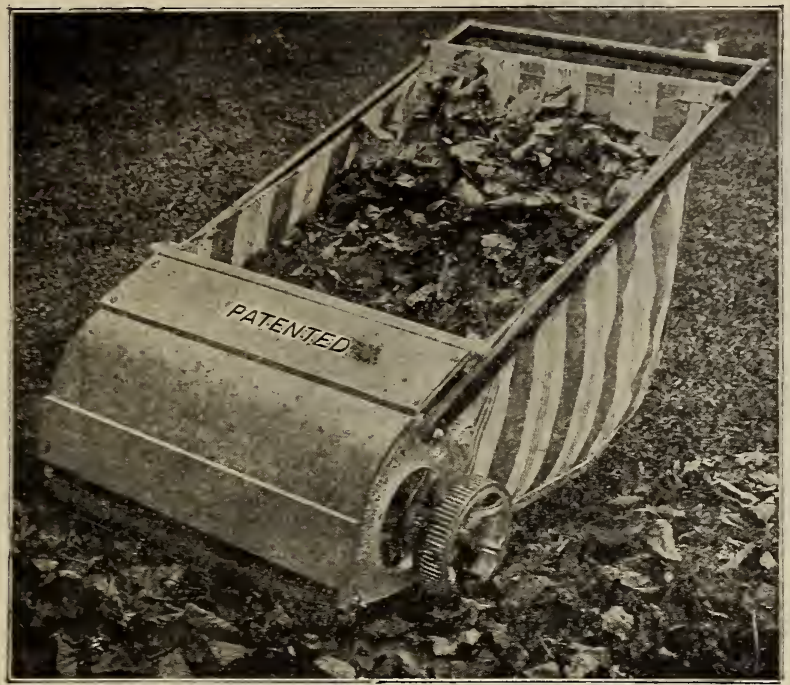

\section{PENNSYLVANIA}

LAWN CLEANER

\section{AND RAKE.}

This machine will remove from the lawn not only the cut grass, but all sorts of litter, leares and trash, leaving the grass standing upright and free from foreign matter that prerents the sunlight and dew from getting to the roots.

Price, $\$ 16.00$.

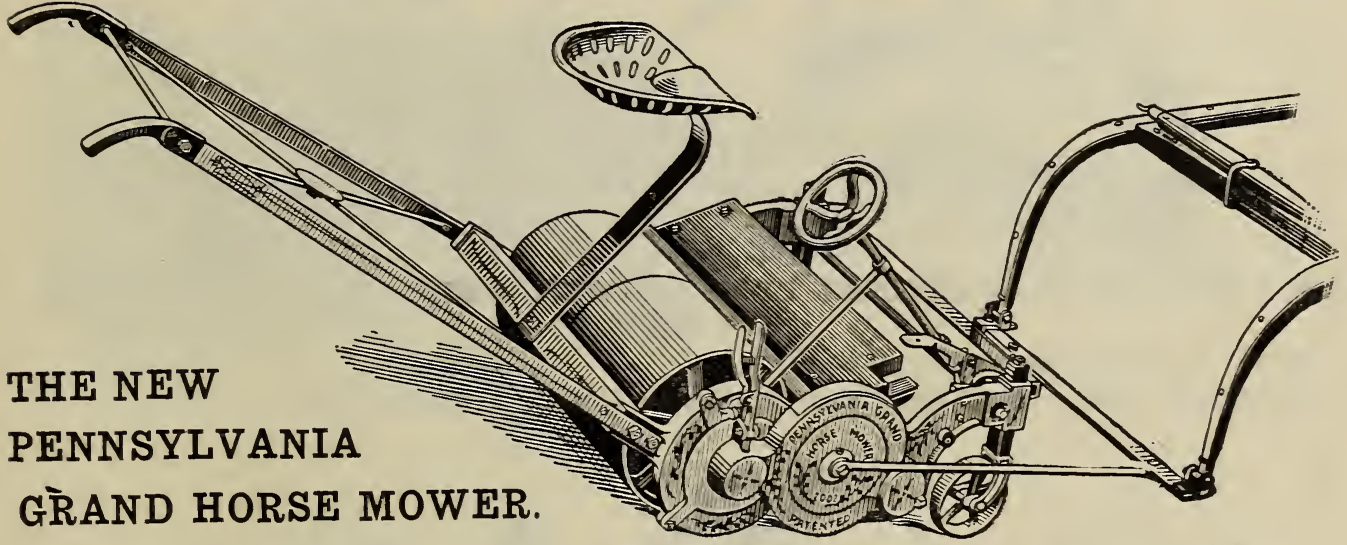

Complete with seat, shafts, etc., as illustrated. Price, 30 inch cut....\$85.00

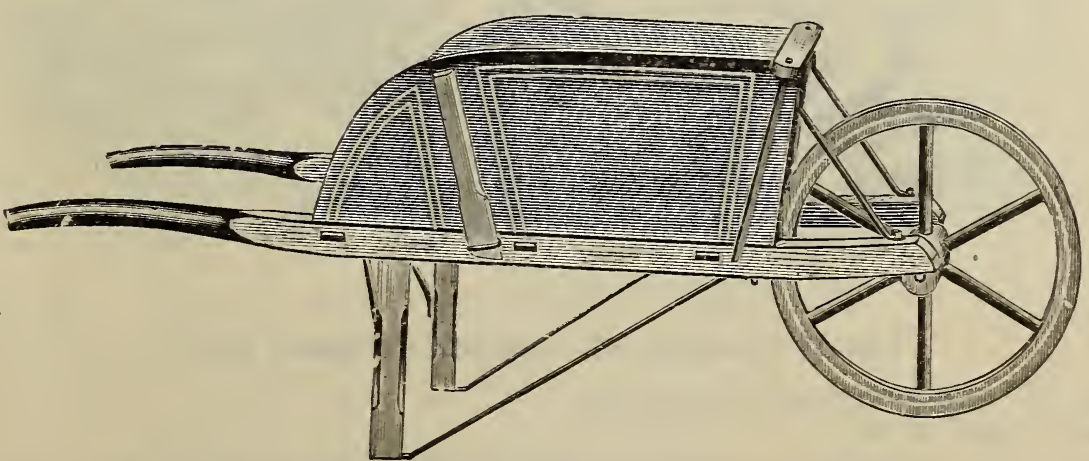

Nicely painted and striped. Bottoms matched and glued.

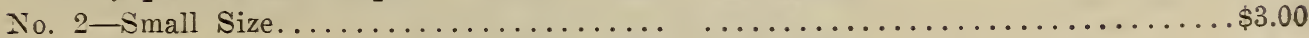

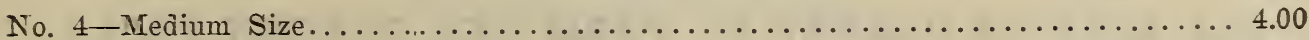

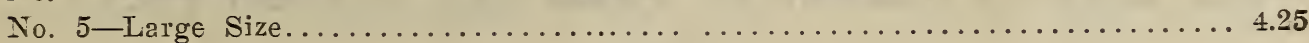




\section{FARM and GARDEN SUPPLIES-Continued.}

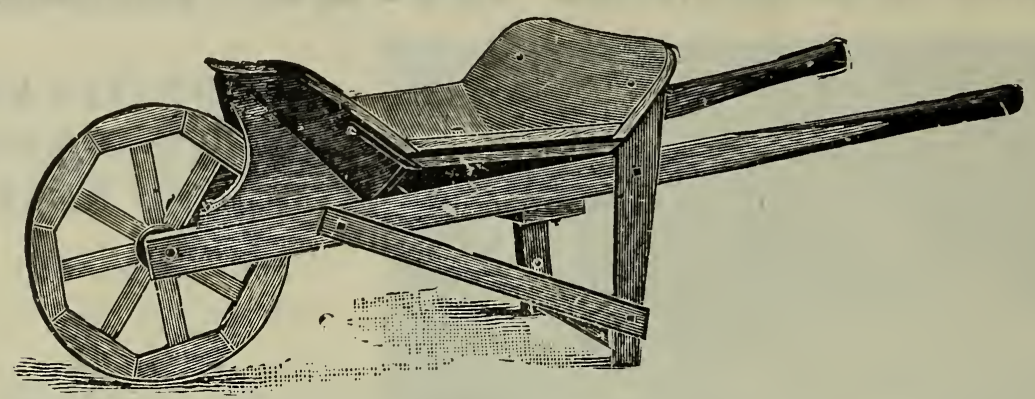

One of the strongest Barrows made. Trays are cleated and bolted to handles. Price, $\$ 2.25$

\section{PLANET JR. FARM AND GARDEN TOOLS.}

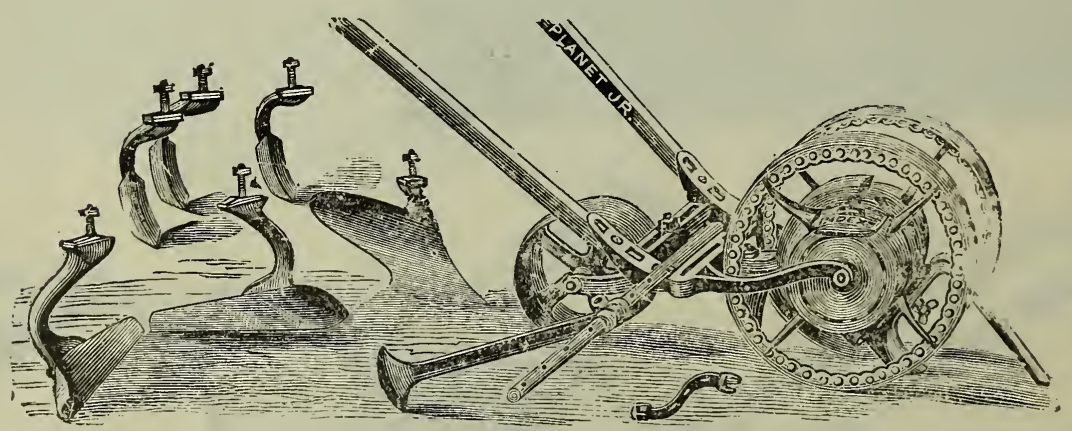

NO. 1 PLANET JR.-COMBINED DRILL SEEDER, WHEEL HOE, CULTIVATOR AND PLOW.

Price, with Tools as Shown, $\$ 9.50$.

Equipment: One pair of hoes, three cultivator teeth, one garden plow.

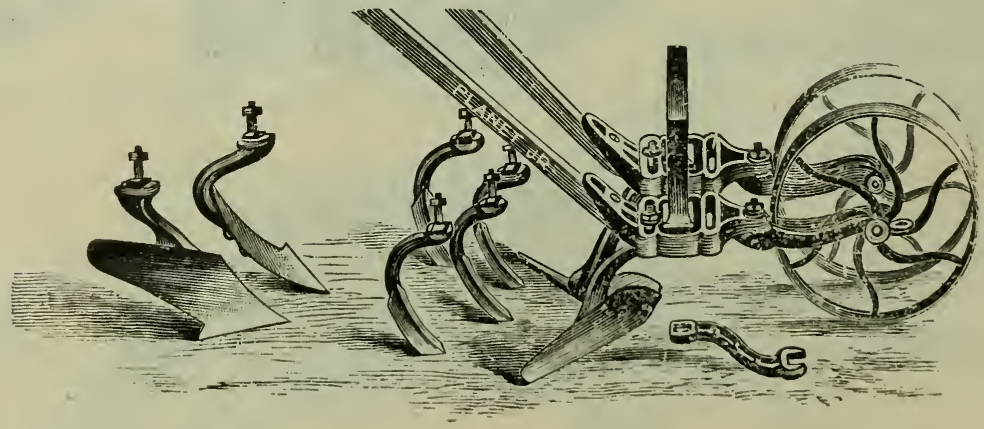

NO. 12 PLANET JR. DOUBLE WHEEL HOE.

Price, with attachments as in cut, $\$ 7.00$.

Packed weight, 32 lbs.

One pair of 6 -inch hoes, two pairs of hollow steel cultivator teeth, one pair of plows, one pair of leaf lifters.

\section{ALL KIND OF PLANET JR. FARM AND GARDEN TOOLS.}




\section{FARM and GARDEN SUPPLIES-Continued.}

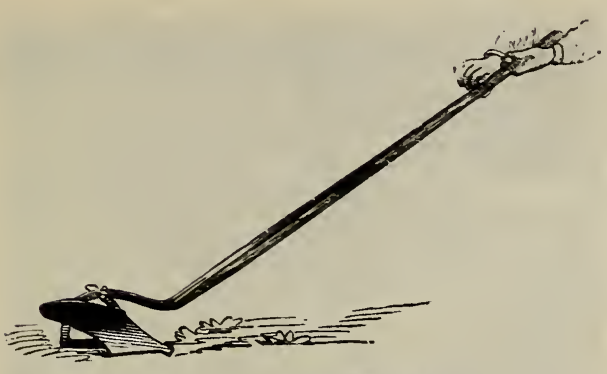

HAND PLOW- $\$ 1.00$

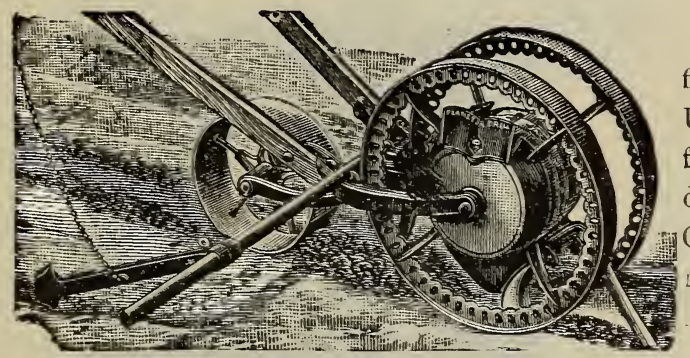

Price $\$ 7.50$. Holds three quarts.

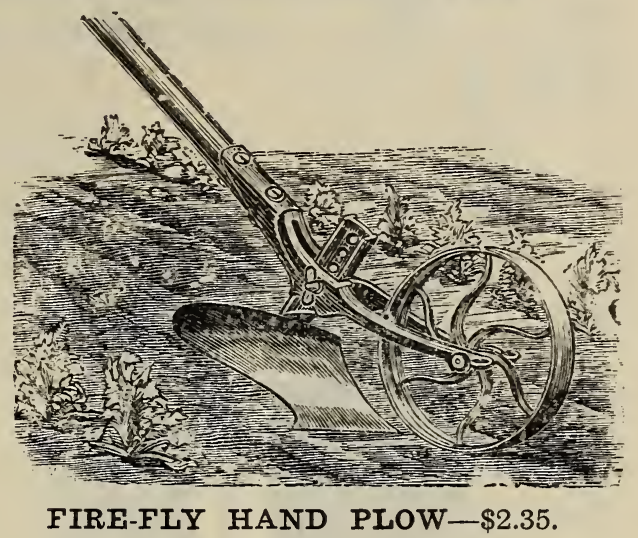

The No. 2 shown herewith is one of the first really good seed drills ever made in the United States. It has given excellent satisfaction for thirty years, and continues to, todar. It is similar to No. 1 PLANET JR. Combined Drill, but larger, holding twice as much seed, and having higher wheels and arger roller.

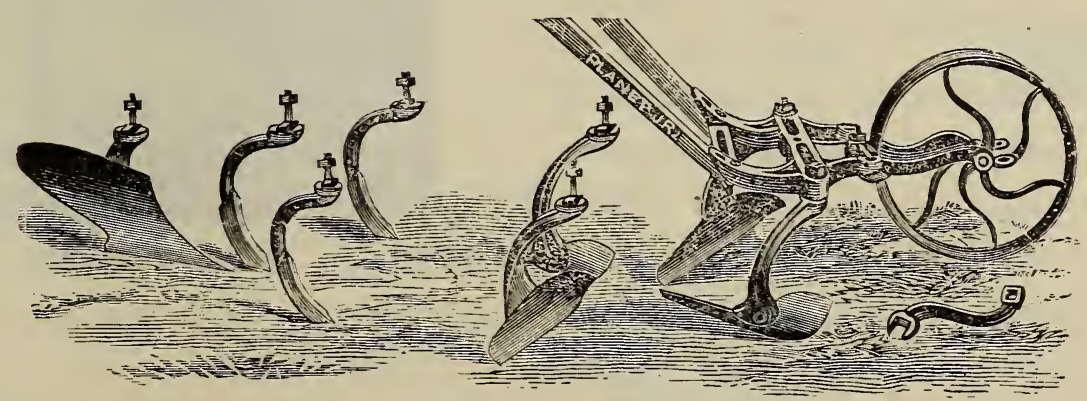

NO. 17 PLANET JR. SINGLE WHEEL HOE.

Price, as in eut, \$5.00. Packed meight, $26 \mathrm{lbs}$.

One parr of 6-inch hoes, three steel cultirator teeth, one large garden plow.

\section{SEEDS-SATTERTHWAITE'S-SEEDS 16 North Warren Street}

Near all suburban trolley terminals.

Opposite Trent Theatre: 
Satterthwaite's Seed Store.-Seeds True to Name-Northern Grown Seed.

\section{FARM and GARDEN SUPPLIES-Continued.}

\section{SATTERTHWAITE'S SEED AND HARDWARE STORE IMPLEMENTS, SEEDS, PAINTS, ETC.}

Phones.

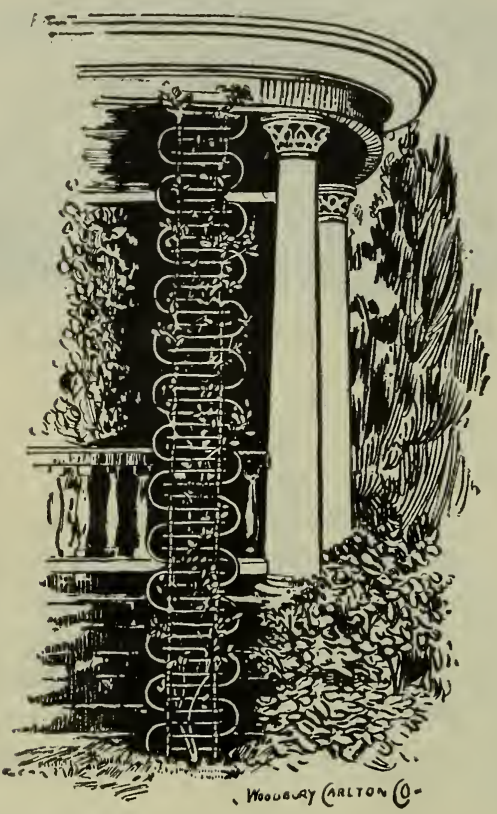

ANCHOR TRELLIS WIRE.

13 inch, 10 cis. per ft.

The American Poultry and Rabbit fence, as now made, is without doubt the best on the market, adequate for all requirements in fencing against poultry, large and small. Hence, for poultry yayds, gardens, orchards and yards, it is a great favorite. Better than the regular Poultry Wire.

Height.

Per Roll. Per Rd.

24 inches . . . . . . . \$3.25

$\$ 0.35$

36 inches............ 3.50

48 inches $\ldots \ldots \ldots \ldots \ldots \ldots+50$

.45

.55

'Top and Bottom Bars, No. 11; Intermediate Bars 13; Stays, 14.
16 NORTH WARREN STREET

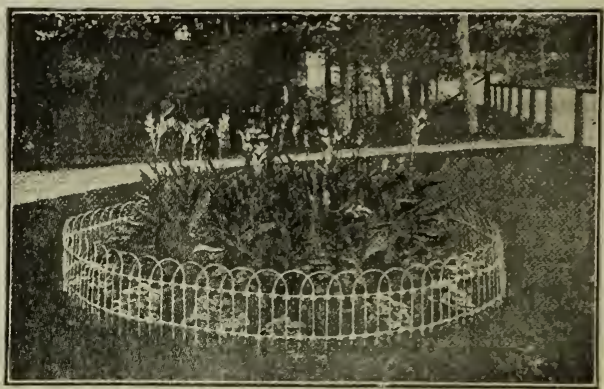

FLOWER BED GUARD.

16 inch, 10 cts. per $\mathrm{ft}$.

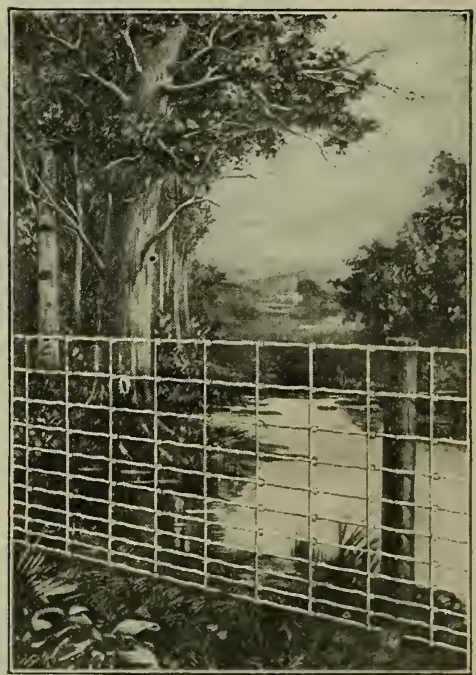

AMERICAN POULTRY FARM FENCE.

See Regular Poultry Wire with Poultry supplies.

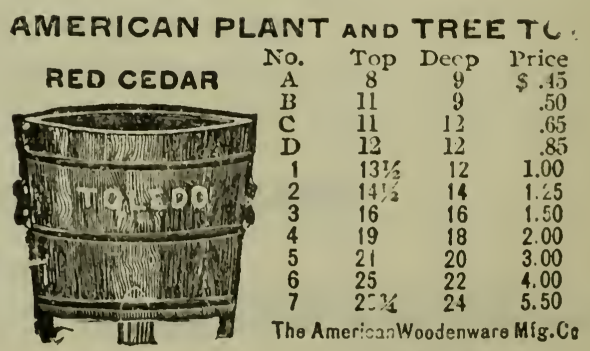

TOLEDO. OHO 


\section{FARM and GARDEN SUPPLIES-Continued.}

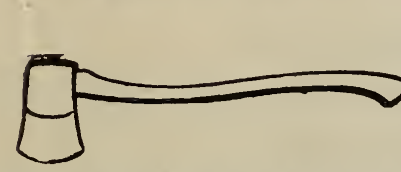

'Man Axes, B e s t' Made, Handled, \$1. Jack Frost A x e, Handled, 85c.

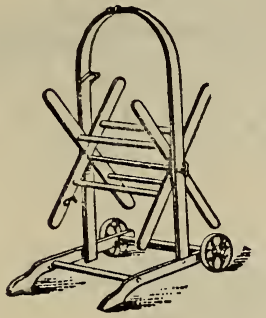

Wooden Hos e Reels -90 ets.

Iron Frame Hose Reels-\$1.50.

Tubular-Best sold, last, forever-\$2.25.

Hose - 5c. per foot up.

Best Red Hose

-15c. per foot.

Extra Quality Woven Hose-16c.

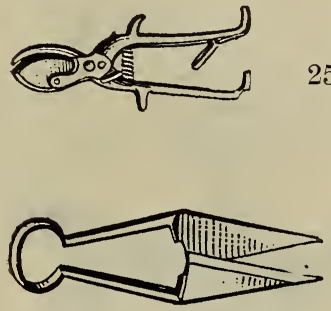

Pruning Shears25c., 75c., 90c.

Grass or Sheep Shears-25c. 50c., 60c., 90c.
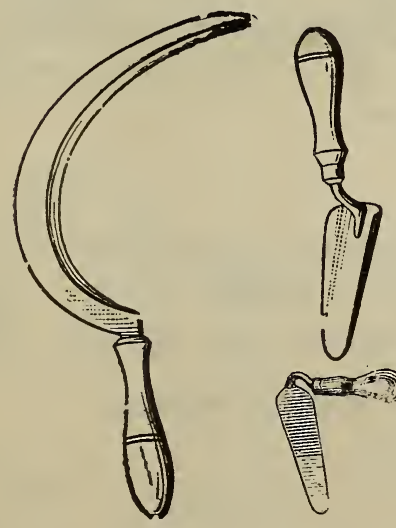

Grass Hooks 15̄c., 25c. and $50 \mathrm{c}$.

Steel Trowels-5c., $10 \mathrm{c}$. and $25 \mathrm{c}$.

Transplanting Trowels, $35 \mathrm{c}$.

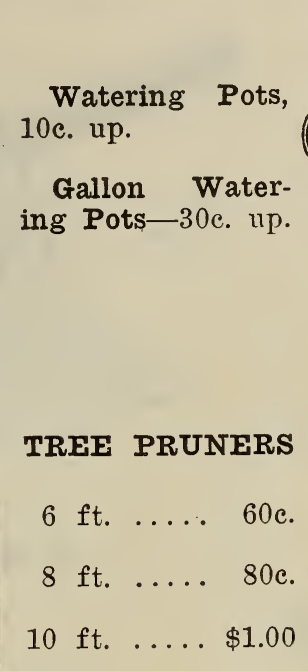

$12 \mathrm{ft} . \ldots \ldots \$ 1.25$

Riveted Field Hoes-25c.

Solid Socket Field Hoes-45̃c.

Riveted Shank Field Hoes-40c.

1 Point Garden Hoes-25c.

2 Point Garden Hoes-30c.

Jersey Truck Hoes-50c.

Schuffle Hoes and Grub Hoes in Stock.

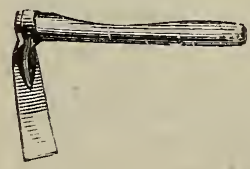

Maddocks- $50 \mathrm{c}$.
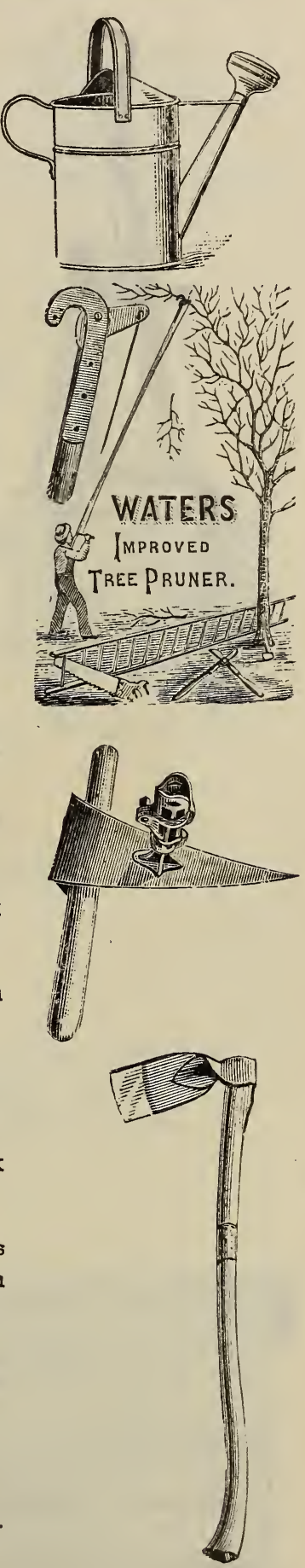

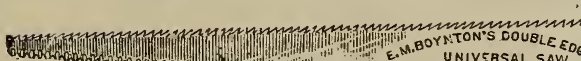

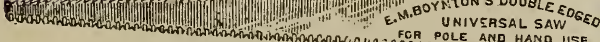

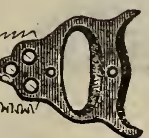

Pruning Saws-65c. and $75 \mathrm{c}$. each. 


\section{FARM and GARDEN SUPPLIES-Continued.}

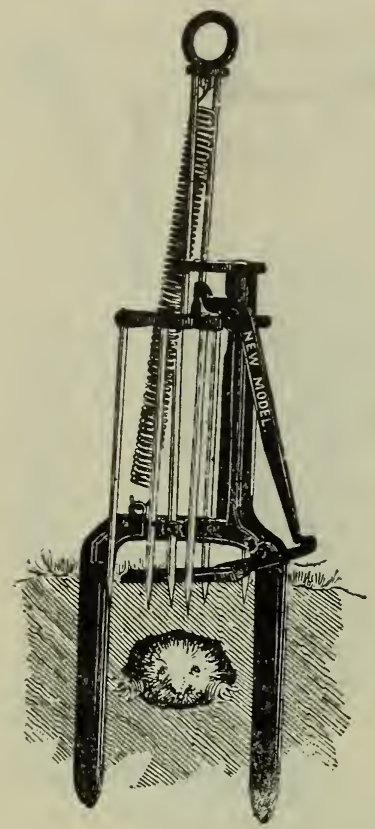

GRINDSTONES.

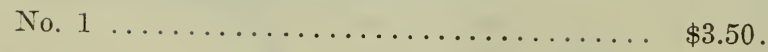

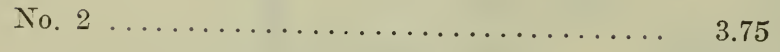

No. 3

Bicycle Grindstones

Come and See Our Royal Grinders.
4.00

4.50

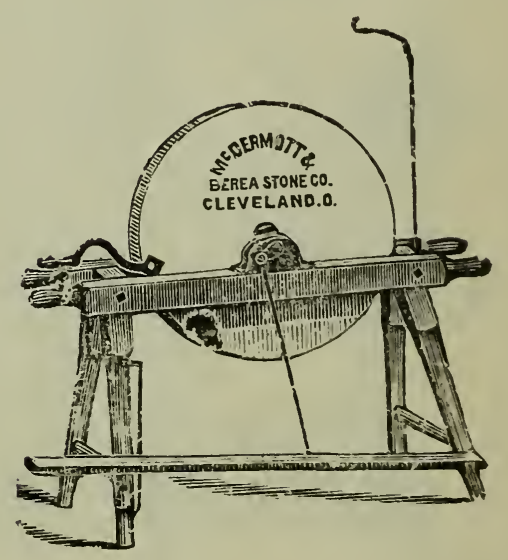

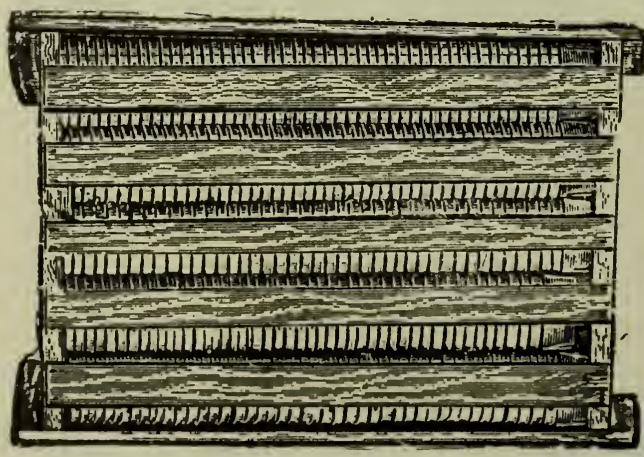

\section{AUTOMATIC RAKES}

MOLE TRAPS- $\$ 1.00$.

\section{ALL KINDS OF BASKETS. Peach Baskets.}

Handled Baszets-10c. and up. QUART BERRY BOXES.

Per $100 \ldots \ldots \ldots \ldots \ldots \ldots \ldots \ldots$. 40 c

Per $1,000 \ldots \ldots \ldots \ldots \ldots \ldots \ldots \ldots .25$

10,000 lots $\ldots \ldots \ldots \ldots \ldots \ldots \ldots \ldots . \ldots . . \ldots$ 


\section{HARDWARE AND PAINTS.}

\section{TOOL CHESTS- $\$ 2.75$ UP.}

Keen Kutter Tool Chests-17 Highest Grades Tools, Regular $\$ 11.00$ Tool Set- $\$ 8.00$. Heary Ash, Cast Brass Padlock.

Keen Kutter Tool Cabinets-Heary Oak Cabinet, Inside Drawers 3 in. deep, Polished Brass Padlock, 26 Highest Grade Tools and Chest, Regular $\$ 2400$ set Tools- $\$ 18.00$.

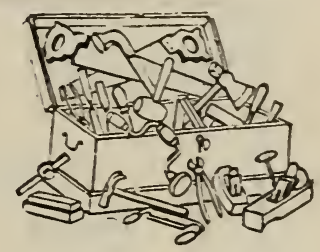

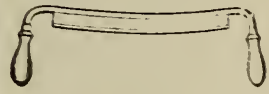
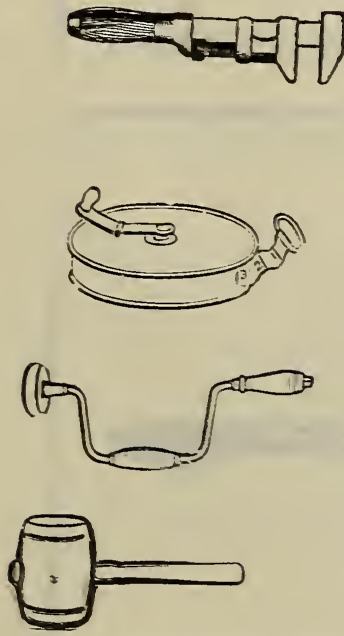

\section{WHITE WASH} BRUSHES.

10 Cents Up.

PAD LOCKS. 10 Cents Up.
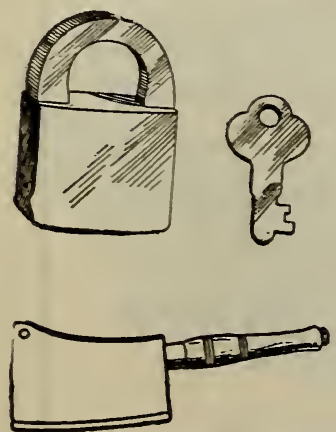

$\$ 1.50$ and $\$ 1.75$.

\section{DRAWING KNIFES - 75 Cents Each}

\section{AGRICULTURAL WRENCHES.}

6 in..... $\$ 0.30$

8 in..... .40

10 in..... .50

12 in...... .60

6 in. Coes. . $\$ 0.60$

8 in. Coes.. .75

10 in. Coes. . .95

12 in. Coes. . 1.25
10 in. Stillson. . $\$ 0.95$

14 in. Stillson. . 1.20

18 in. Stillson.. 1.40
TAPE MASURES-25 Cents Up.

PLAIN BRACES-60c. RATCHET BRACES- $\$ 1.00$.

MALLETS-20 Cents.

HAND-MADE MALLS-\$ $\$ .50$.

BUTCHER CLEAVERS.

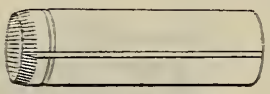

STOVE PIPE.

4 in. Pipe, per length. . 12c. $4^{1 / 2}$ in. Pipe, per length. . 14c 5 in. Pipe, per length. . 16c. $5^{1 / 2}$ in. Pipe, per length. . 18c. 6 in. Pipe, per length. . 20c.

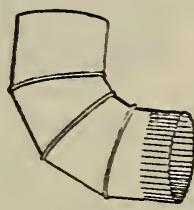

ELBOWS.

4 in. Elbows ....... 15e. $4^{1}, 6$ in. Elbows ....... 15c 5 in. Elbows ....... 15e. 51,2 in. Elbows ....... 15c. 6 in. Elbows ......... 15c. 


\section{HARDWARE AND PAINTS-Continued.}

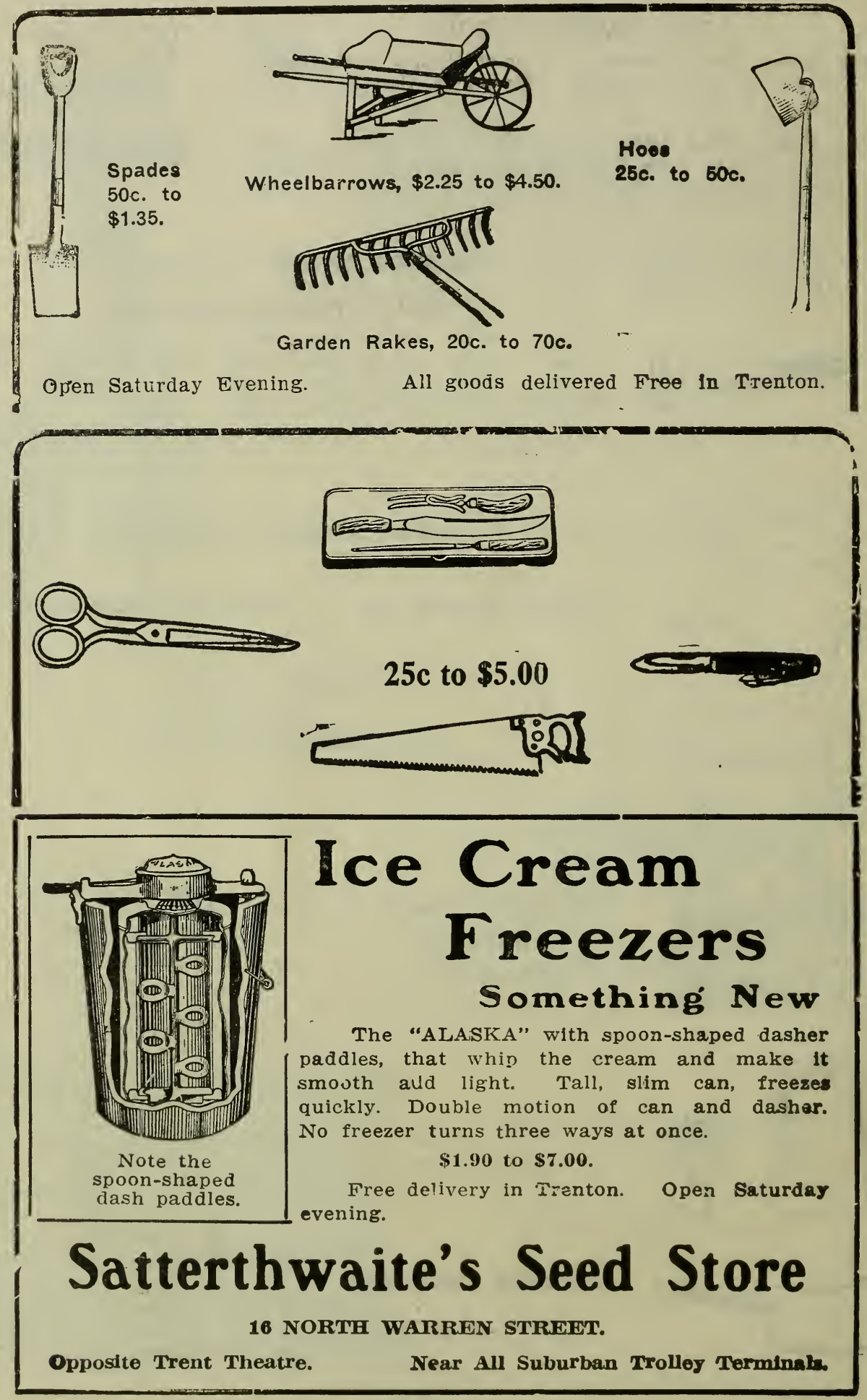




\section{HARDWARE AND PAINTS-Continued.}

\section{HAMMOCKS.}

$\$ 1.00, \$ 1.50$. \$2.00. See Ours Before You Buy.
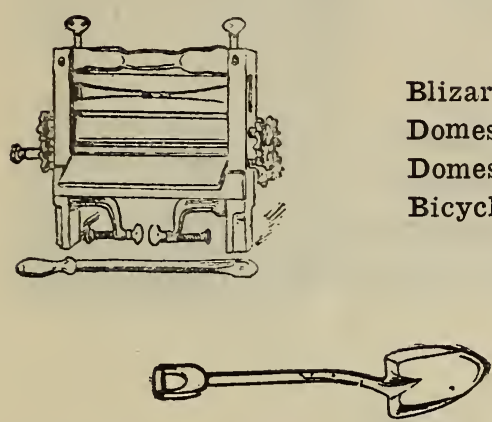

ROUND POINTED SHOVELS-60c. each.

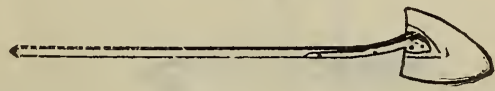

SHOVELS-Long Handle, Round Point-

DOINTE SHOVELS-60c. each.

\section{0c., 60c., $\$ 1.35$.}

\section{CLOTHES WRINGERS.}

Blizard Clothes Wringers $\ldots \ldots \ldots \ldots \ldots \ldots \ldots \ldots . \$ 2.50$

Domestic Clothes Wringers ................ 3.00

Domestic Ball Bearing Clothes Wringers ......... 3.50

Bicycle Greatest Ever Ball Bearing ........... 4.00

SEE OUR BOSS WASHING MACHINE.

\section{PICKS}

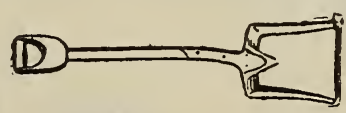

SQUARE POINTED SHOVELS-

50c., 60c., $\$ 1.00$ and $\$ 1.35$.

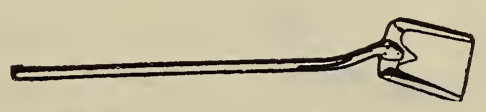

SHOVELS-Square Point60c., 70c. and $\$ 1.35$.
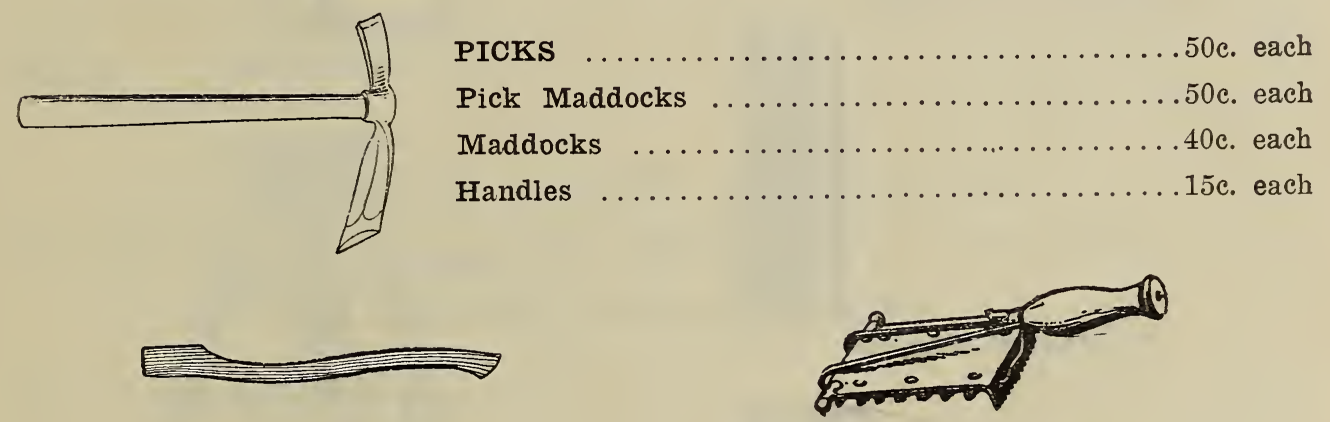

AXE HANDLES-15c. each. CURRY COMBS-10c, 15c, 18c and 20c.

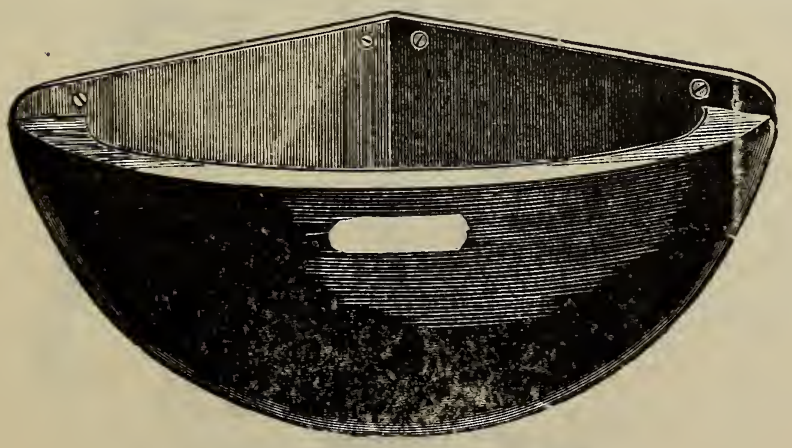

FEED MANGERS. \$1.10 Each.

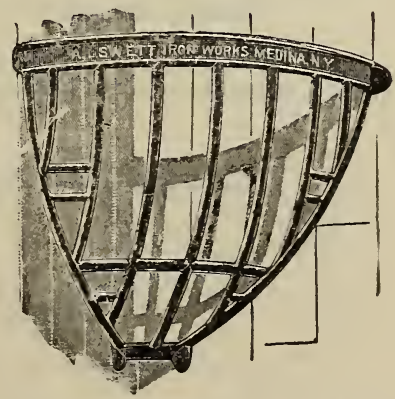

HAY RACKS, \$1.20 Each. BUY SATTERTHWAITE'S WARRENOID ROOFING. 


\section{HARDWARE AND PAINTS-Continued.}

\section{FLY SCREEN WIRE.}

Solid Bronze.-Will last a lifetime. Per square ft., $8 \mathrm{c}$.

Galvanized.-Very durable. Per square ft., 4c.

Painted.-Best Green and Black Wire Cloth. Square ft., $21 / 2 \mathrm{c}$.

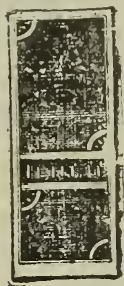

SCREEN

DOORS.

$\$ 1.00, \quad \$ 125, \quad \$ 1.50$.

\section{WINDOW SCREEN FRAMES.}

A strong, worth putting together frame, complete, $35 \mathrm{c}$.

They slide in grooves easily put together.

\section{WINDOW} SCREENS.

Hardwood Frames, 30c., 35c., 50c. and 60c.

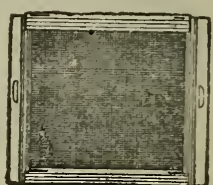

\section{COME AND SEE OUR TOOLS.}

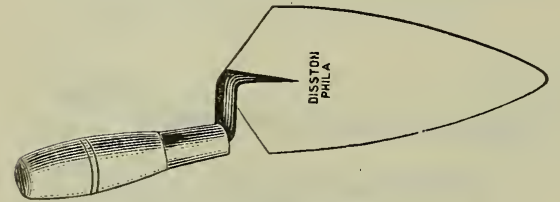

MASON TROWELS-10c. to $\$ 1.40$.

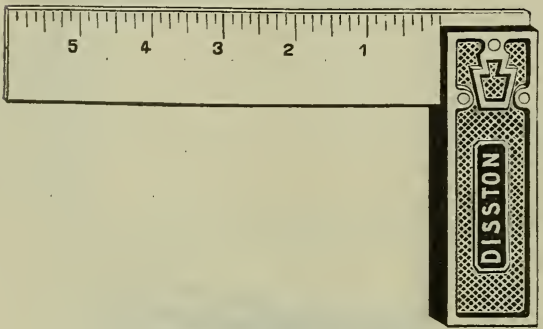

SQUARES-25c. up.

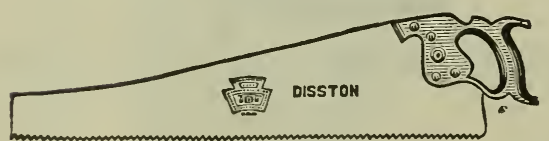

HAND SAWS-75c. up.

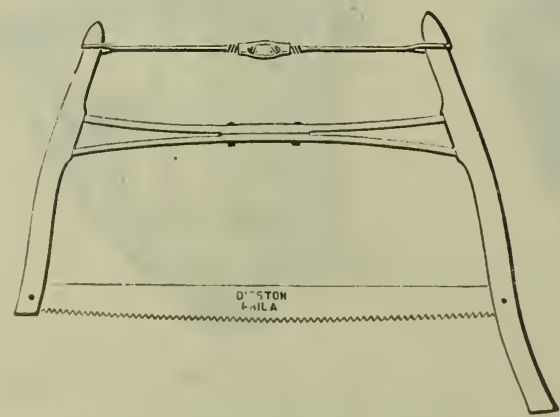

BUCK SAWS-45c. and $75 c$.
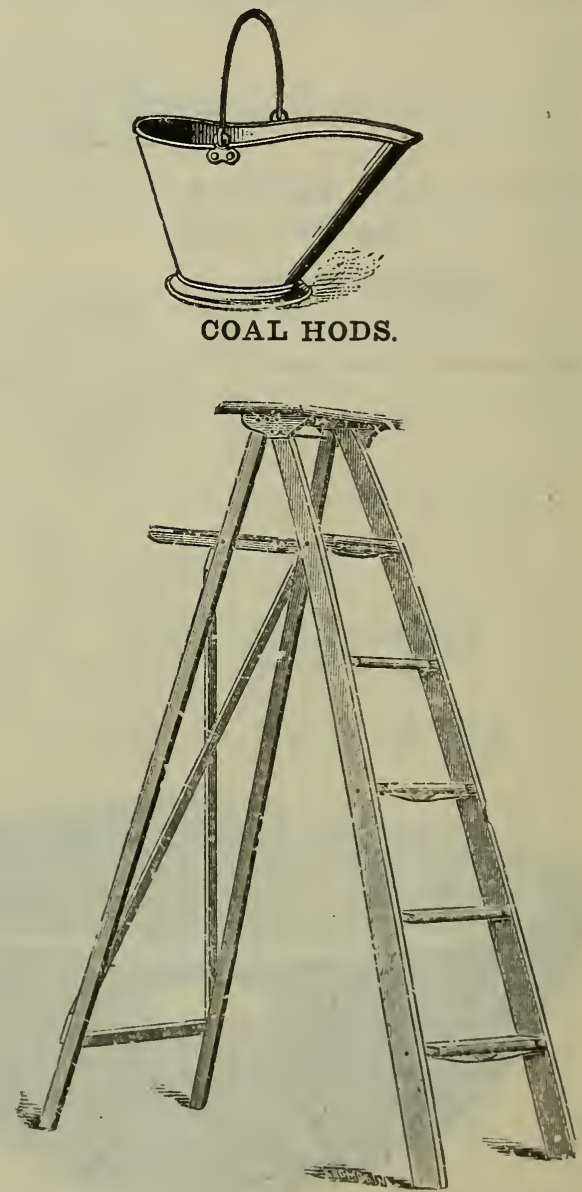

STEP IADDERS-20c. and 30c. ft. Straight Ladder ...........15c. ft. Extension Ladder ............ 


\section{HARDWARE AND PAINTS-Continued.}
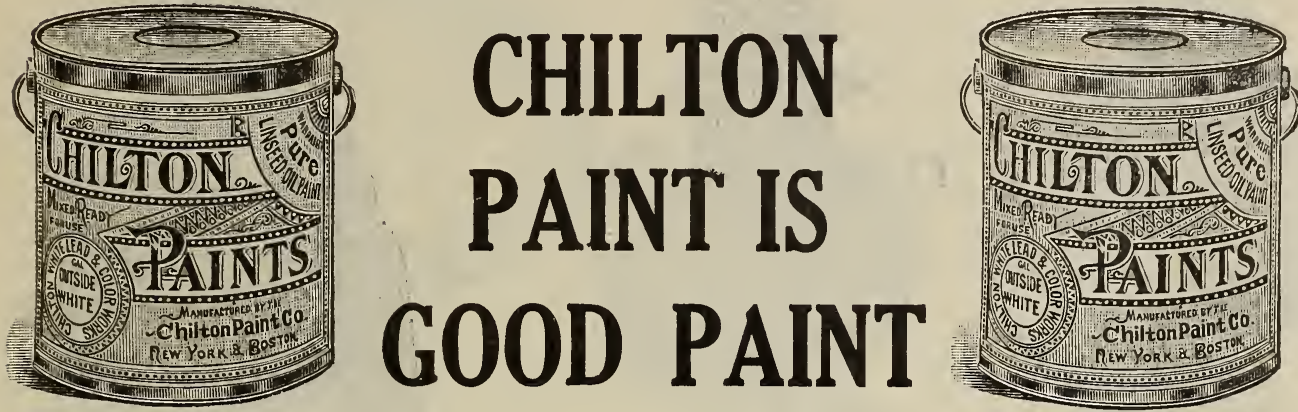

Most people know nothing about paint-are absolutely at loss what to get for a job of painting. Must depend on the advice of some painter who may lack experience, or upon the suggestion of some dealer who may be prejudiced. Just one safe plan for such to follow-use a paint with a reputation for excellence, which puts its worth beyond all question-such a paint is CHILTON-Best in the World.

\section{CHILTON PAINTS AND COLORS}

Varnishes, Japans, Glass, Putty, White Lead, Brushes, Turpentine. Everything in the Paint Line.

Chilton Paint, Regular Color..............per Gal., \$2.00

Chilton Red Barn Paint ................per Gal., 1.45

Chilton Red Roof Paint ................per Gal., 1.30

\section{JUST ONE CHEAP PAINT}

That's Good Paint

All the Rest are Dear.

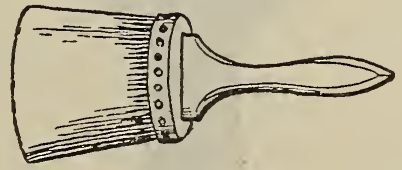

CALL AND GET A COLOR CARD. 


\section{HARDWARE AND PAINTS-Continued.}

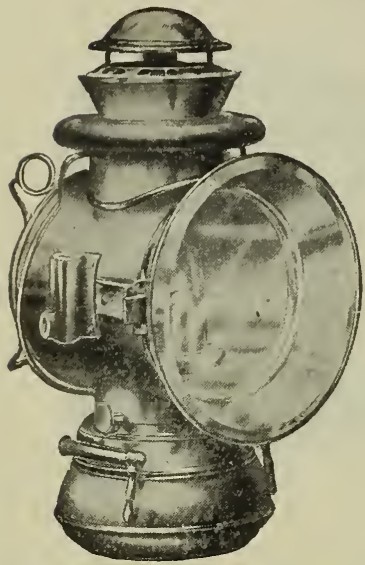

Hains Driving Lamps, Diezt Union and Octo Driving $\$ 2.75$.

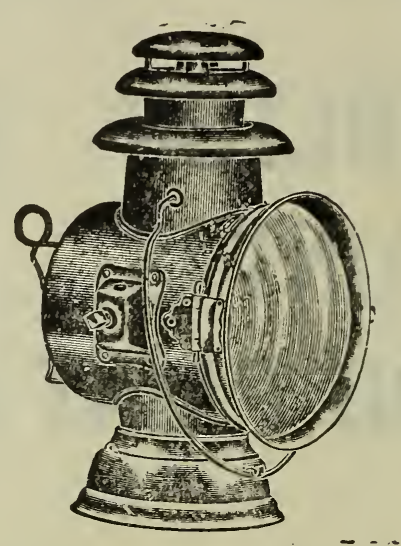

Lamps, \$2.75.

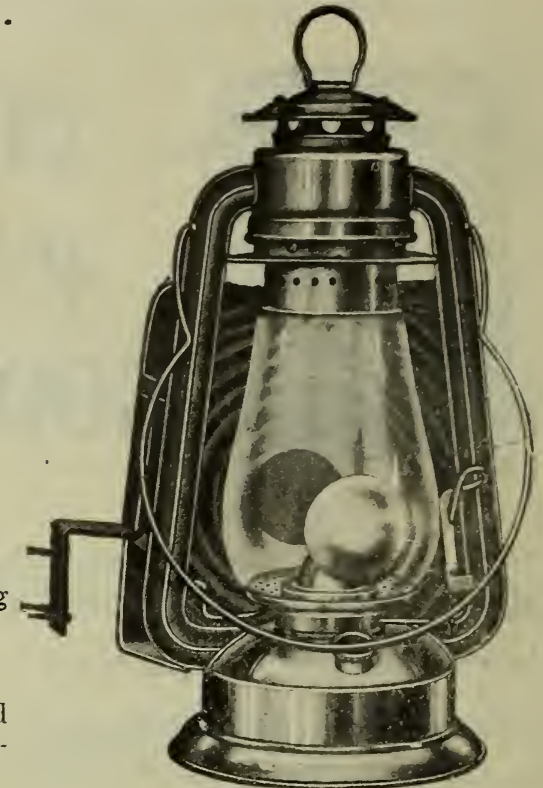

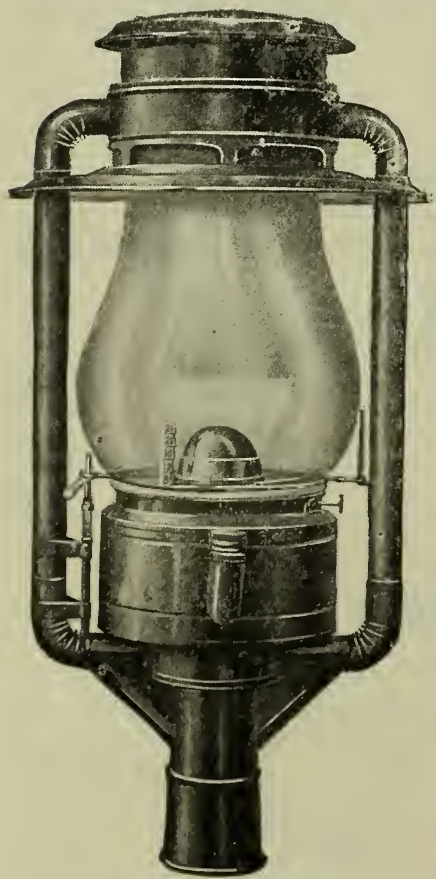

Street Lamps, $\$ 3.75$ each.

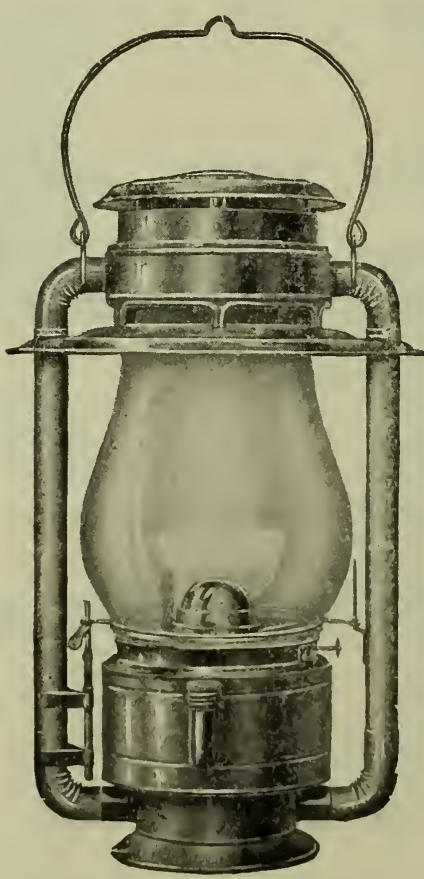

Large Hanging Lamps, $\$ 3.75$ each.

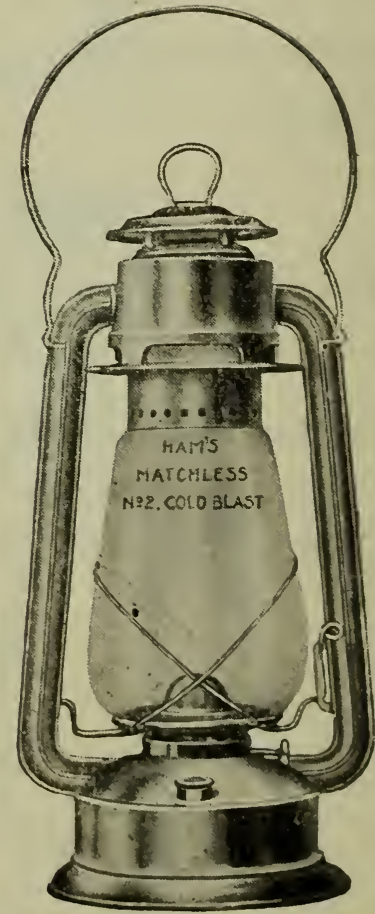

Hains Cold Blast Lantern, 85c. each.

Lanterns, 50 Cents each. 


\section{INSECTICIDES.}

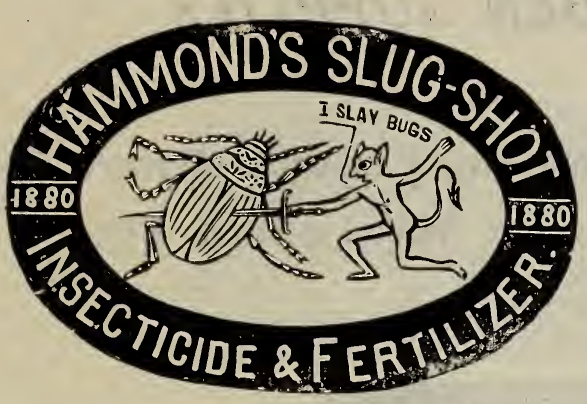

Arsenate of lead used upon potatoes. 1 lb. package 20 cts., 5 lb. package 75 cts. Slug Shot will kill all kinds of bugs and worms injurious to garden plants. It is one of the best destroyers for bugs upon cabbage and potatoes. Per lb. 10 cts., 5 lbs. 25 ets.

Target Brand Weed Killer.-Used by street railways, cemeteries, parks, and individuals for killing grass and weeds on roadway and paths, tennis courts and ball diamonds, walks and gutters. Destroys roots as well as tops. One gallon with 50 gallons of water is sufficient to cover 100 to 150 square yarus; and one or two applications last an entire season. Prices: Qt. 45 cts., gal. $\$ 1.00,5$ gals. $\$ 4.50,10$ gals. $\$ 8.50$.

“'Target Brand', Scale Destroyer.-This preparation has been compounded with a view to give the fruit-grower, and others who desire to spray, every possible advantage possessed in soluble oils. In making T. B. S. D. there is not one drop of crude oil used, consequently it possesses none of the dangerous qualities of the latter.

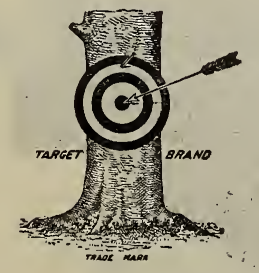

Target Brand Scale Destroyer dilutes readily in any water, has a milky appearance and is positively neutral. It cannot penetrate the tree, nor can it injure the most delicate growth. It kills the scale by suffocation and not by penetration, as in the latter process the tree suffers.

It has no caustic action, will not injure hands, clothing, eyes, body or spraying apparatus, and the results are evident 4 to 6 weeks after its application. In dilution it is very econonical-covering just onethird more space when applied than lime, sulphur and salt, and it likewise covers more space than most other oil preparations.

Dilution: In winter and early spring, 1 gallon T. B. Scale Destroyer to 20 gallons of water; late spring, \& gallon T. B. Scale Destroyer to 25 gallons of water; summer, 1 gallon T. B. Scale Destroyer to 40 gallons of water. Per gal. can 80 cts., per 5 gal. can $\$ 3.10$.

Bordeaux Mixture.-Highly recommended as a reliable remedy for the prevention of fungus and fungold diseases such as leaf blight on fruit trees, grapes, etc. Per lb. 15 ets., 5 lbs. 50 ets.

Hellebore.-Powdered white Hellebore for rose slugs, currant worms, etc. Dust on with gun or bellows while the foliage is moist. 1 lb. 25 ets.

Kerosene Emulsion.-The best and cleanest insecticide for general use on all plants indoors, or are ready for use by adding water, 25 to 50 parts of water to 1 of emulsion. Per qt. 40 ets., gal. \$1.10.

Paris Green.-Used generally upon potatoes and cabbage: Per lb. 25 cts. Prices in quantity upon application.

Whale Oil Soap makes an excellent wash for trees and plants; kills insects and eggs in the bark. 20 cts. per package. Prices in quantity upon application.

Tobacco Dust.-If dusted on while the foliage is moist it destroys rose lice, capbbage and turnip fleas. Spread upon the ground it keeps off earth insects and acts as a fertilizer. Per lb. 10 cts., $10 \mathrm{lbs} .50$ cts. 


\title{
FARM and GARDEN SUPPLIES
}

\author{
Paris Green, Hellebore, Sulphur, Lime, Dry Bordeaux Mixture, Bor- \\ deaux and Paris Green Compound, Tobacco Dust, Etc.
}

Will Green two

Rows of Potatoes at Once, as Fast as a man walks.

Adjustable to any width of row, wide or narrow planting.

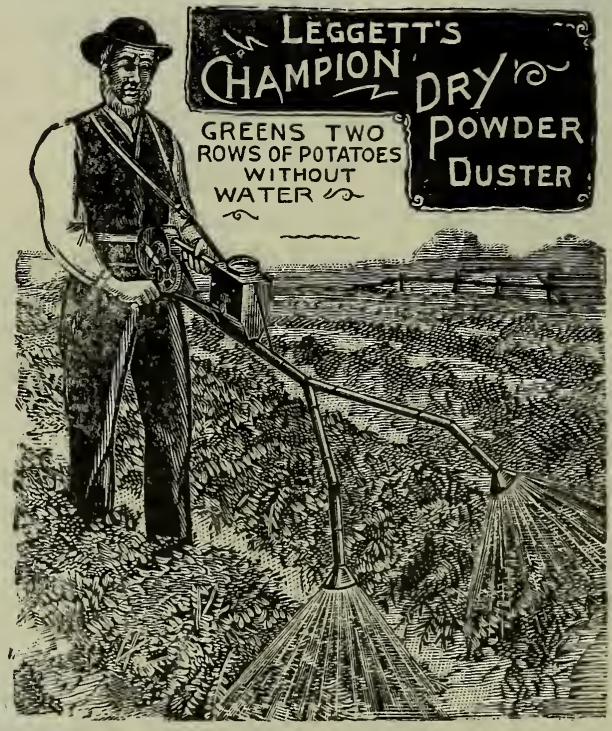

In general use many years

Thousands sold annually

The length of the CHAMPION is such that the poison is kept at a safe distance from the operator.

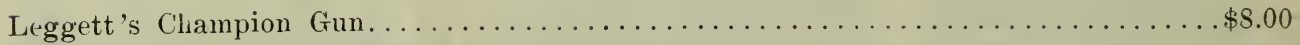

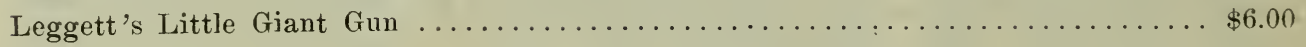

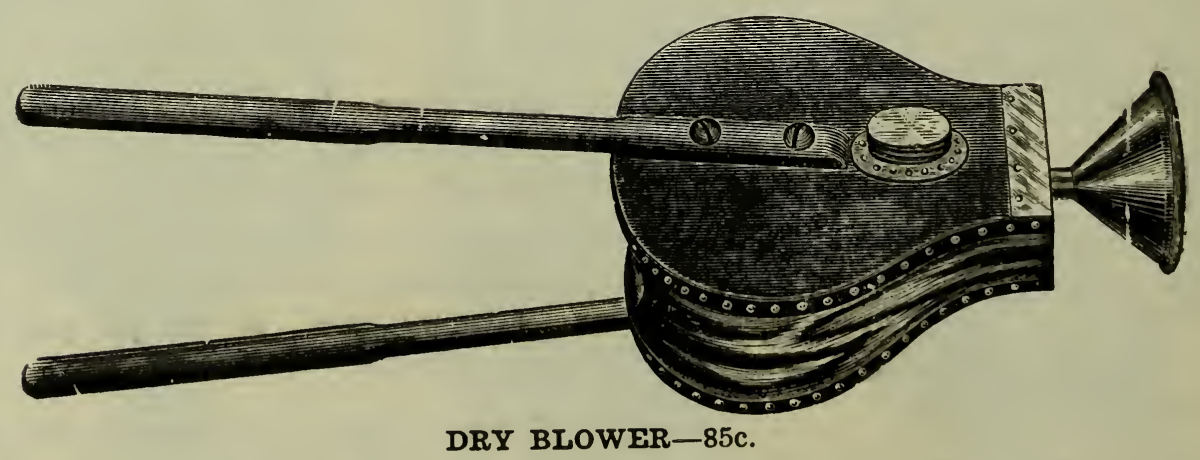

Get a Sample of Satterthwaite 's Warrenoid Roofing. 


\section{FARM and GARDEN SUPPLIES-Continued.}

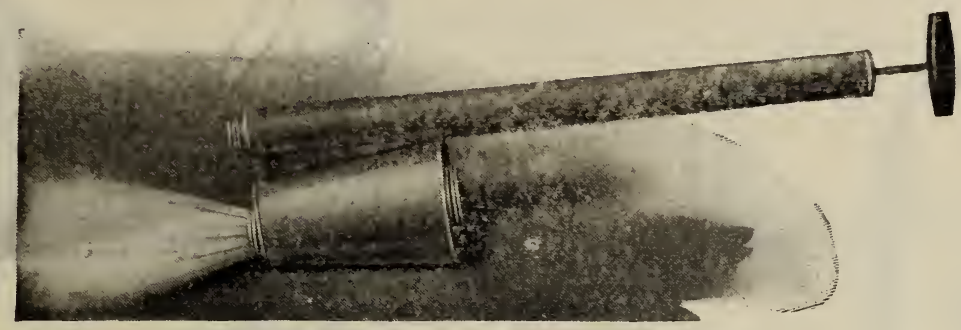

The Loweli Blow Powder Sprayer for Potato Growers, stock and poultry raisers, for paris green and disinfectants. The new and best powder gun on the market. 70 cts. each.

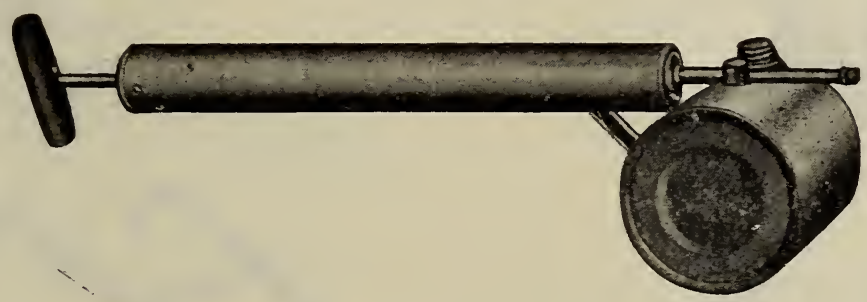

The Lowell Continuous Sprayer, as the name implies, is so constructed that it not only sprars on the downward stroke of plunger, but also when it is drawn back, thus causing a continuous mist-like spray. $70 \mathrm{cts}$. each.

Sprayer is fitted with a $3-16$ inch brass ball check ralre which is positire in its action. and practicalls indestructible.

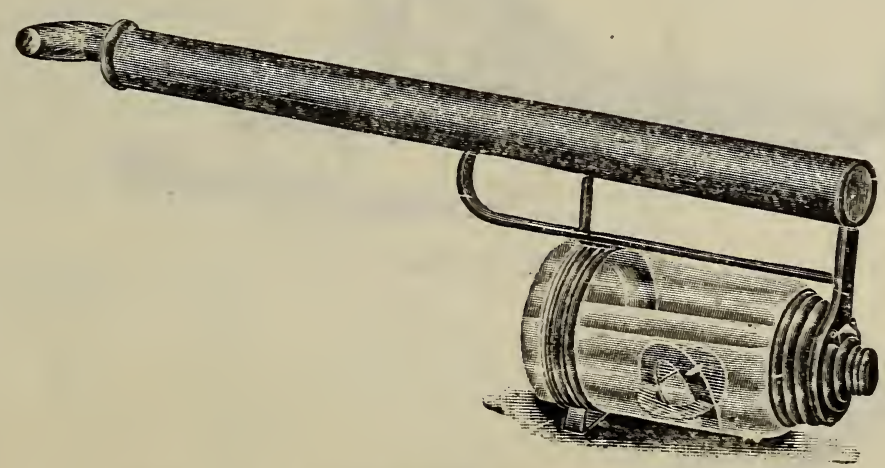

REGULAR GLASS SPRAYER, 70 cts. each.

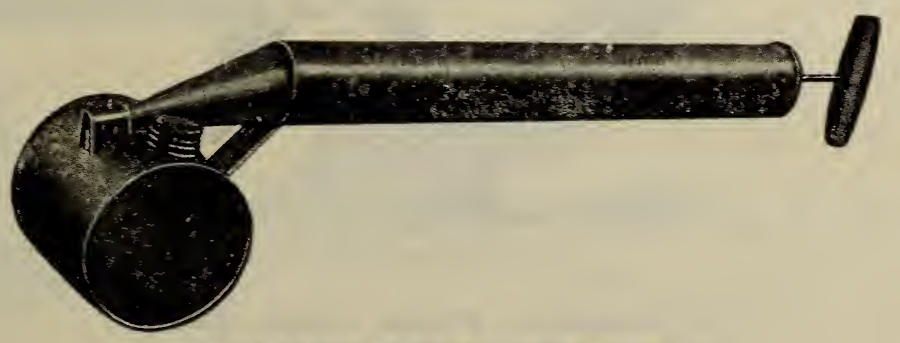

REGULAR SPRAYER, 50 cts. each. ... . . . 


\section{FARM SUPPLIES.}
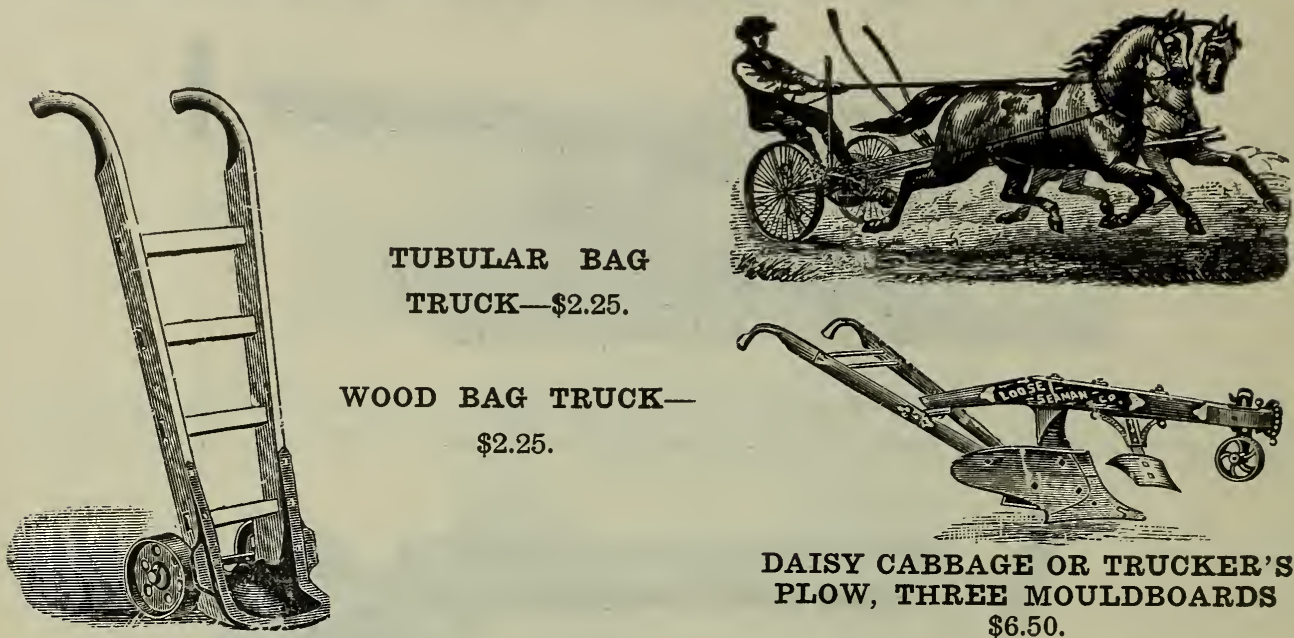

DAISY CABBAGE OR TRUCKER'S PLOW, THREE MOULDBOARDS $\$ 6.50$.

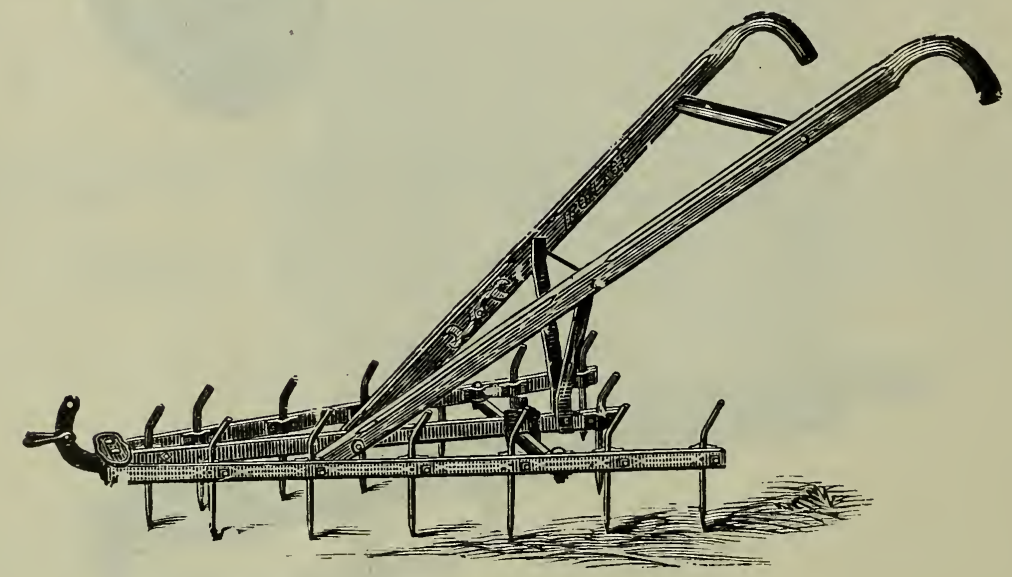

14 TOOTH HARROW, $\$ 4.00$.

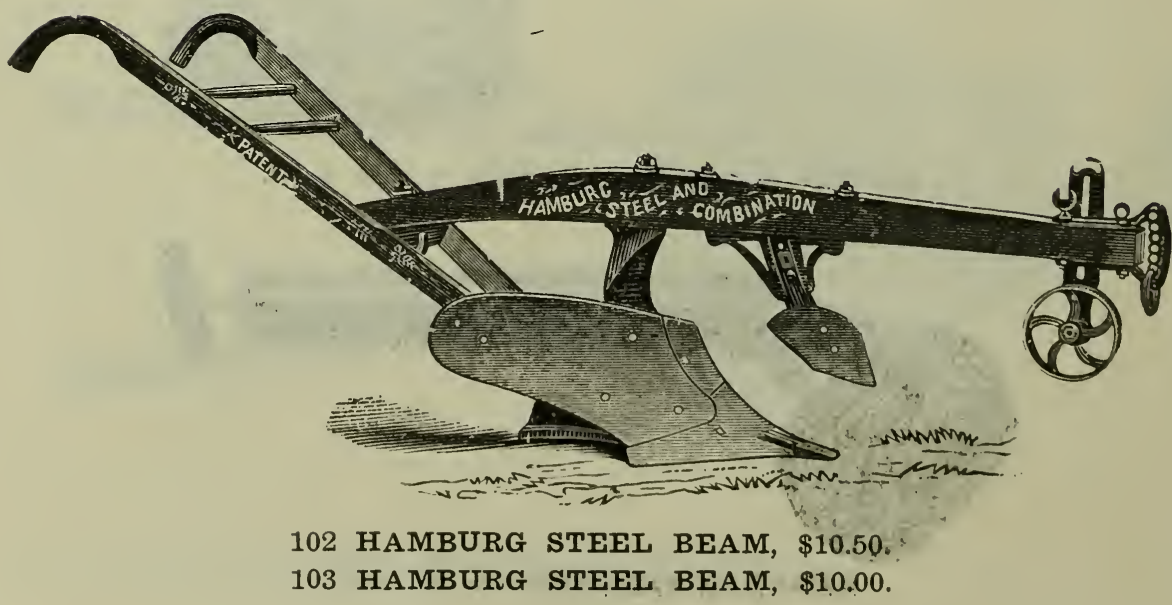




\section{FARM SUPPLIES-Continued.}
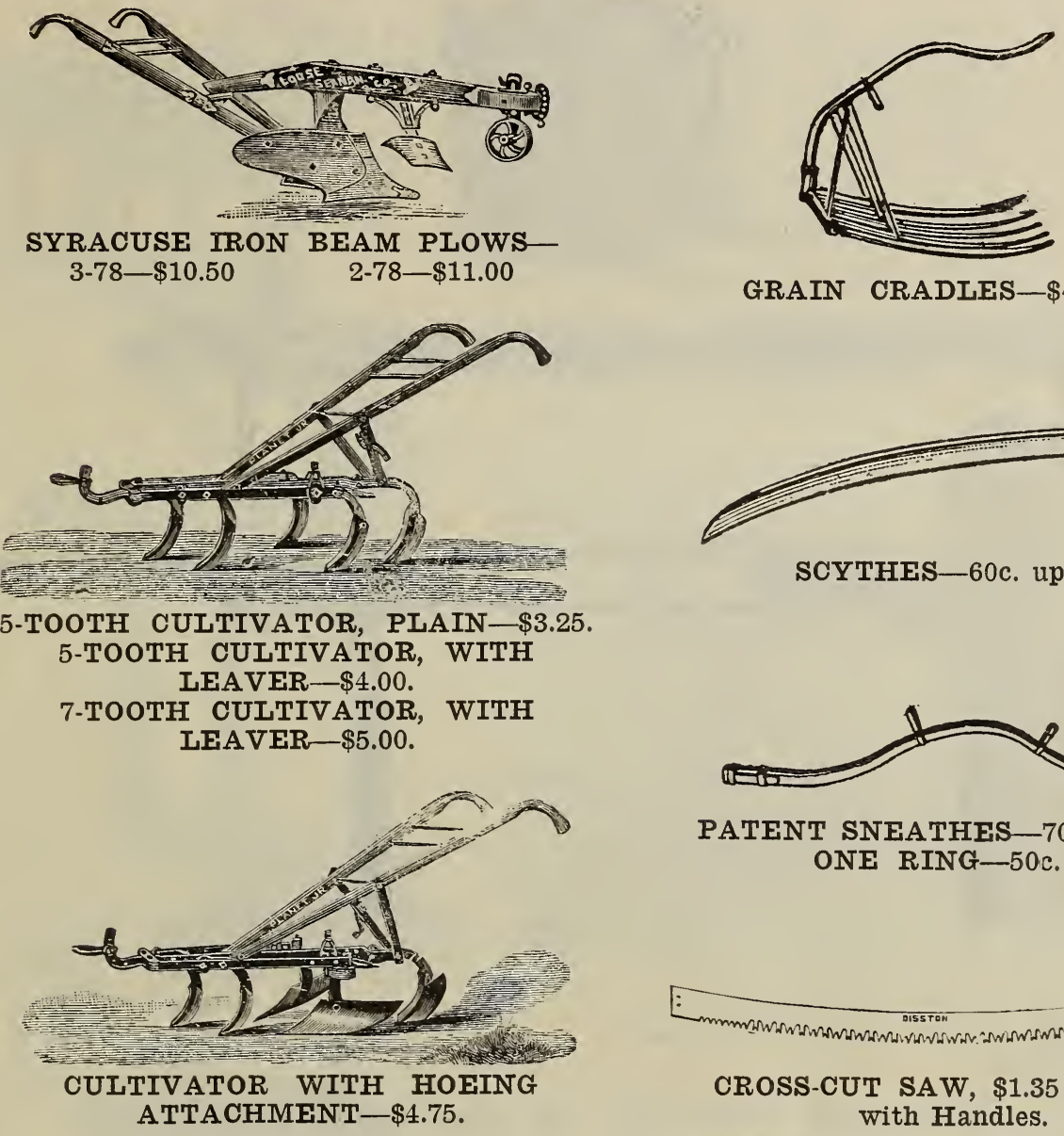

GRAIN CRADLES- $\$ 4.00$.

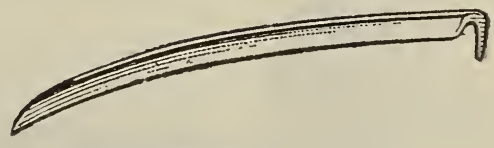

SCYTHES-60c. up.

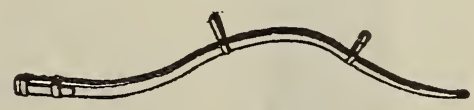

PATENT SNEATHES-70c. each. ONE RING-50c.

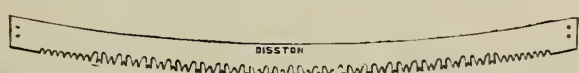

CROSS-CUT SAW, $\$ 1.35$ to $\$ 1.60$, with Handles.
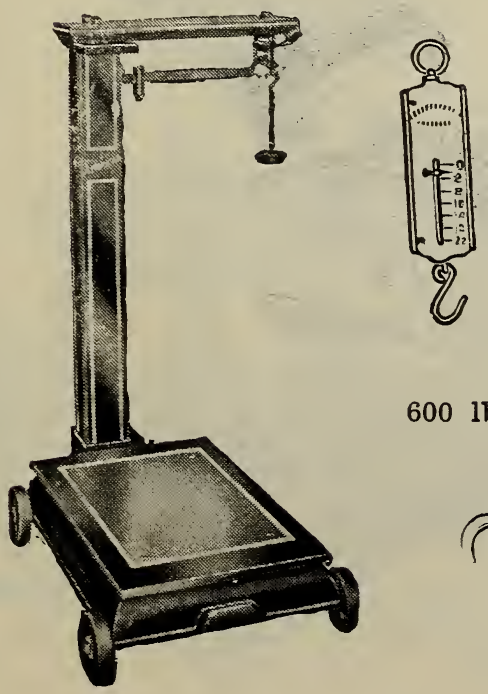

\section{SPRING} BAIANCES, $15 \mathrm{cts}$. to $50 \mathrm{cts}$

ICE SCALES, $\$ 2.25$.

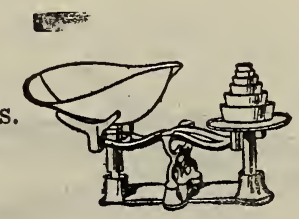
SCALES AS OPPOSITE, Cut, 75 cts. up.

AMERICAN SCALES.

$600 \mathrm{lbs} \ldots . . . \$ 10.00$

1,000 lbs....... $\$ 15.00$

HEDGE HOOK. 


\section{FARM SUPPLIES-Continued.}

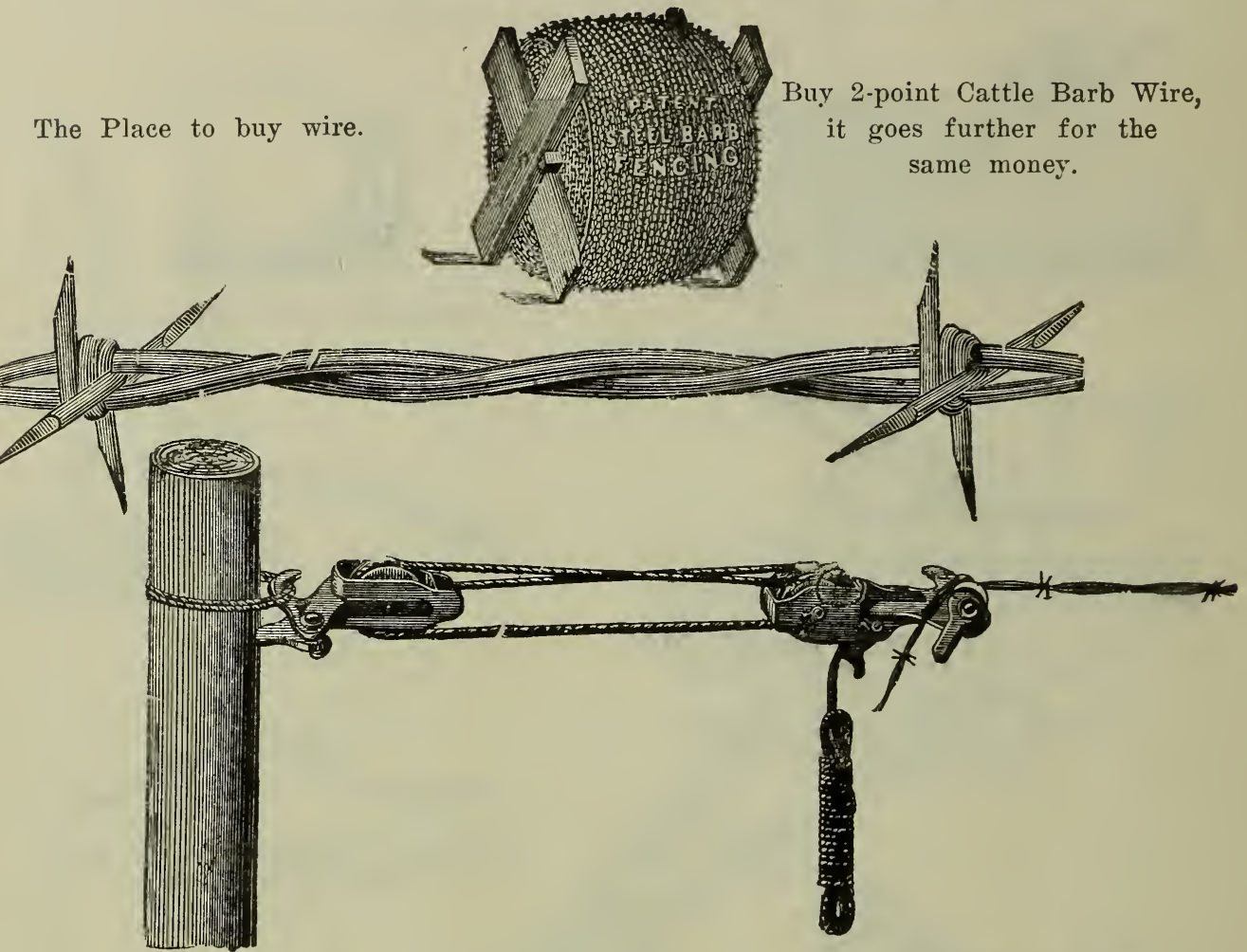

The Place to buy wire

1 Coil. 10 Coils. 20 Coils.

Per 100 Per 100 Per 100

lbs. lbs. lbs.

BARB WIRE

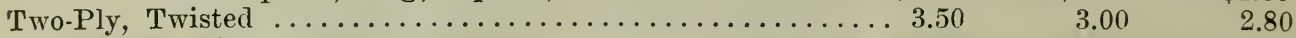

No. 9 Field Wire $\ldots \ldots \ldots \ldots \ldots \ldots \ldots \ldots \ldots \ldots \ldots \ldots . \ldots \ldots . .50 \quad 3.00 \quad 2.80$

See page 36, American fence Poultry Wire. See Poultry Supply page.

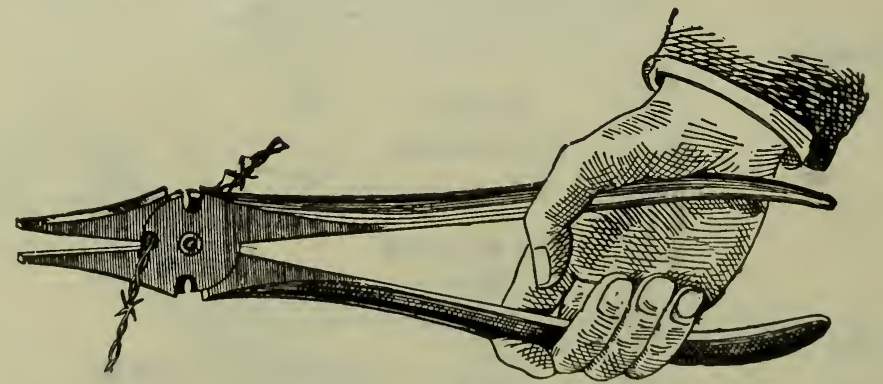

BARB WIRE CUTTERS AND PLYERS AND STAPLE PULLERS.

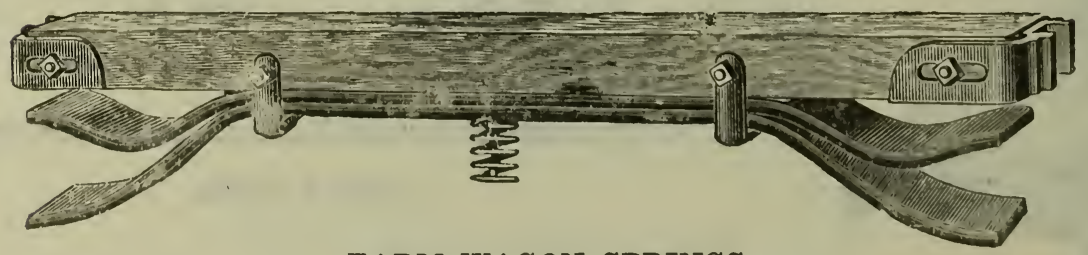

FARM WAGON SPRINGS. 


\section{FARM SUPPLIES-Continued.}

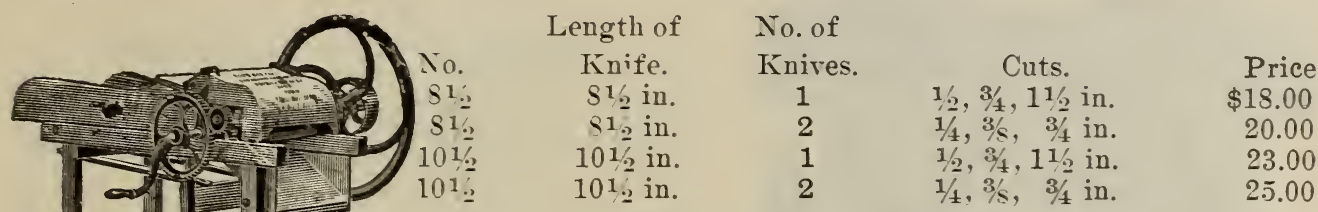

HAND FODDER CUTTER- $\$ 1.00$.

No. 111/4 FODDER CUTTER-\$14.00.

Cost You 10 Per Cent. off List.

See us for Circular and Price on Power Machine.

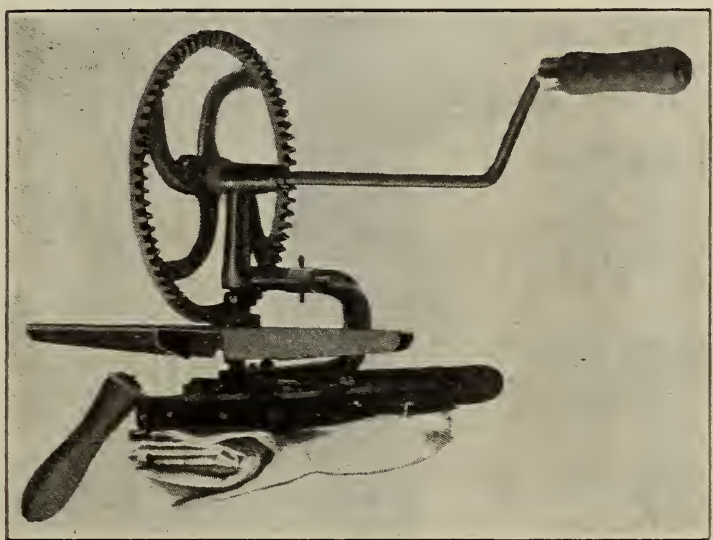

PREMIER SEEDER- $\$ 1.00$.

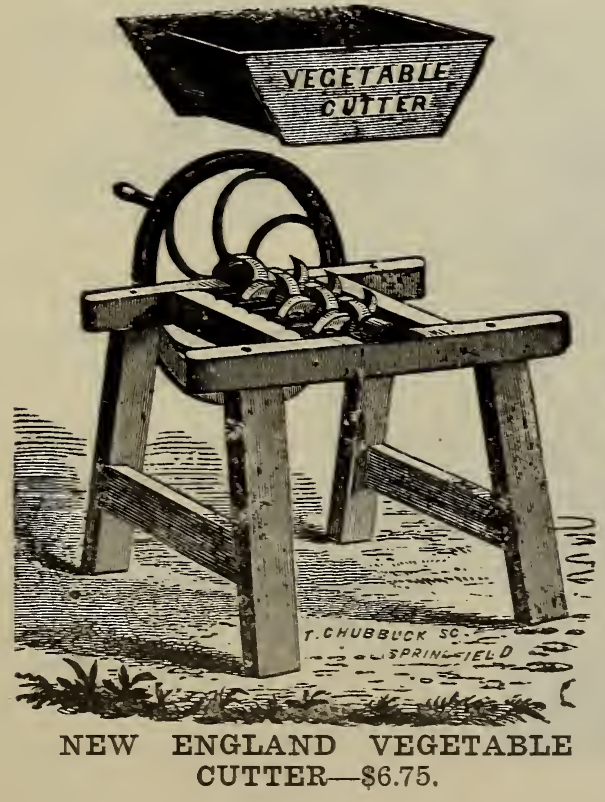


Satterthwaite's Seed Store.-Seeds True to Name-Northern Grown Seed.

\section{FARM SUPPLIES-Continued.}

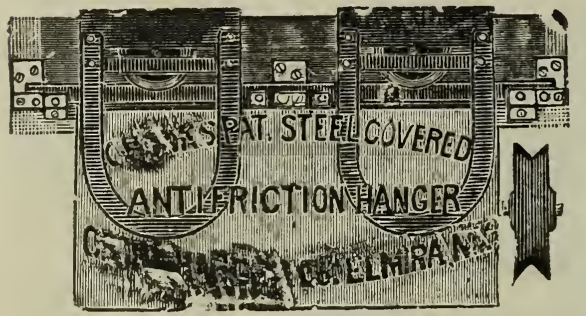

No. 0. Per Pair ................ 45c.

No. 1. Per Pair ............... 55c.

No. 11/2. Per Pair ................. 65c.

No. 2. Per Pair ............... 80.

Track, Per ft. ............... 5 c.

20th CENTURY

BARN DOOR

HANGERS.

Best Made.

Will Not Jump

the Track.

Per Pair,

$\$ 1.25$.

Track, Per Ft.,

10 Cents.

Let us show them

to you.
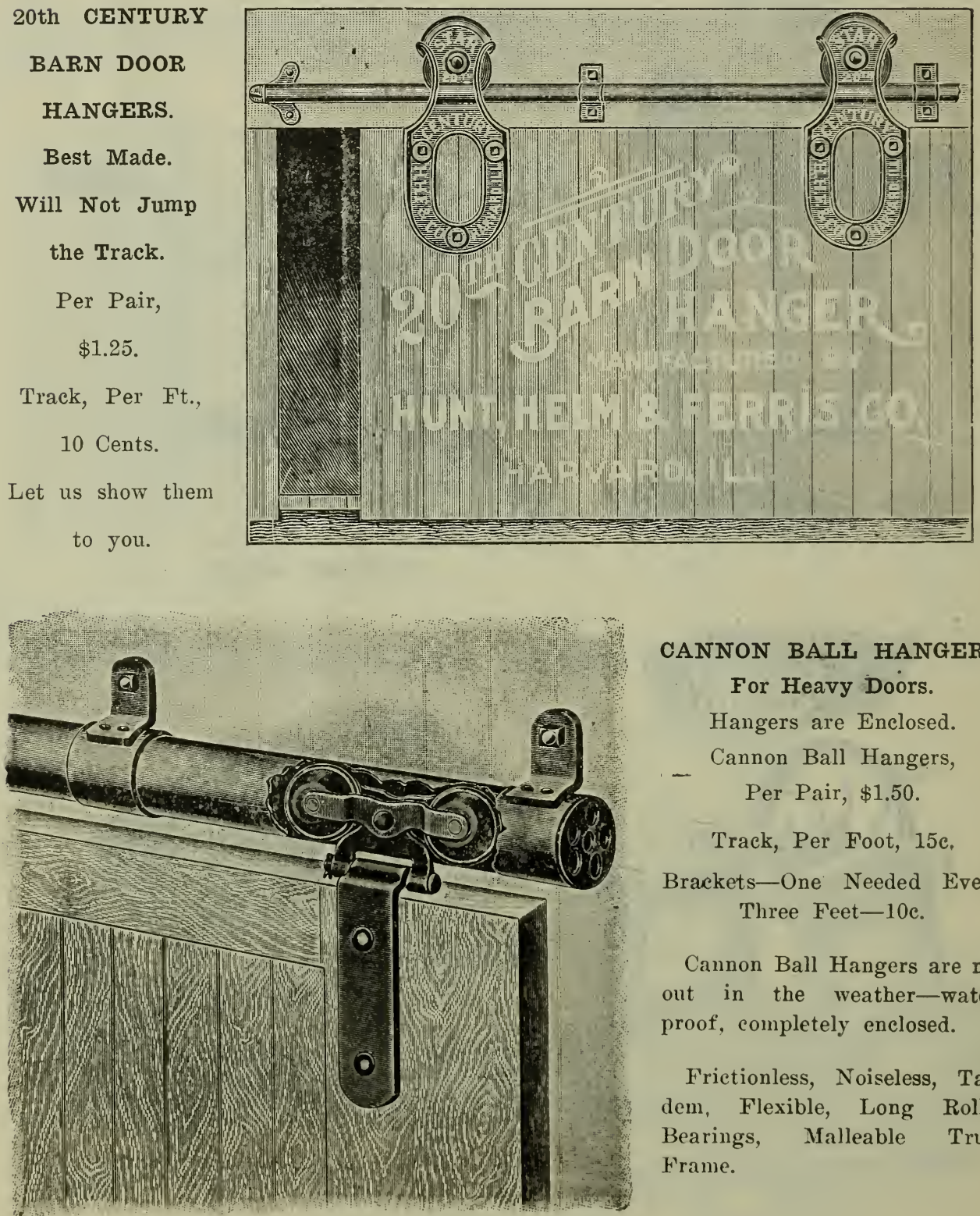

CANNON BALI HANGERS.

For Heavy Doors.

Hangers are Enclosed.

Cannon Ball Hangers,

Per Pair, \$1.50.

Track, Per Foot, 15c.

Brackets-One Needed Every Three Feet-10c.

Cannon Ball Hangers are not out in the weather-waterproof, completely enclosed.

Frictionless, Noiseless, Tandem, Flexible, Long Roller Bearings, Malleable Truss Frame. 


\section{FARM SUPPLIES-Continued.}

ENTERPRISE FOOD CHOPPERS.

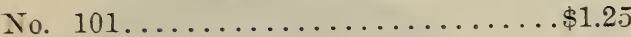

No. $102 \ldots \ldots \ldots \ldots \ldots \ldots \ldots . . .50$

ENTERPRISE MEAT AND FOOD CHOPPER.

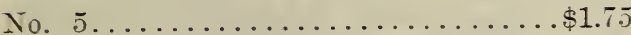

Yo. $10 \ldots \ldots \ldots \ldots \ldots \ldots \ldots \ldots . .2 .50$

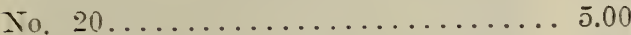

No. $22 \ldots \ldots \ldots \ldots \ldots \ldots \ldots \ldots .4 .00$

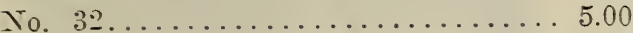

\section{ENTERPRISE SAUSAGE STUFFER,} LARD AND FRUIT PRESS.

4 qt. Press $\ldots \ldots \ldots \ldots \ldots \ldots \ldots \ldots+.50$

6 qt. Press ................. 5.00

s qt. Press $\ldots \ldots \ldots \ldots \ldots \ldots \ldots . .5 .50$

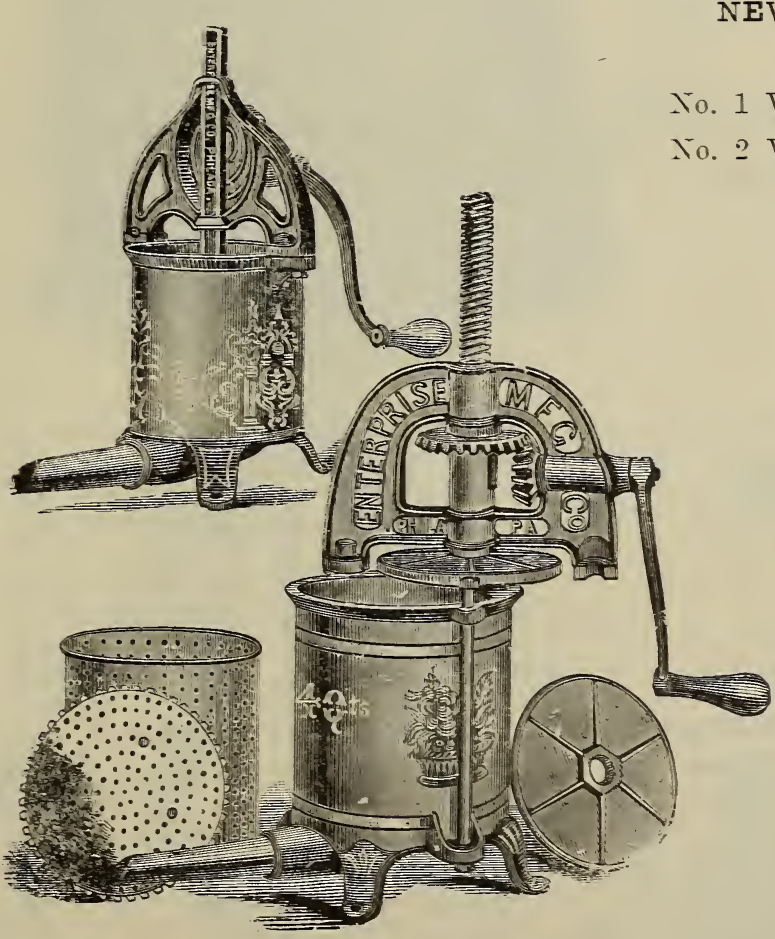

NEW PATENTED CORRUGATED SPOUT.

To. 1 Tine Press.............. \$3.75

o. 2 Tine Press............... 4.75

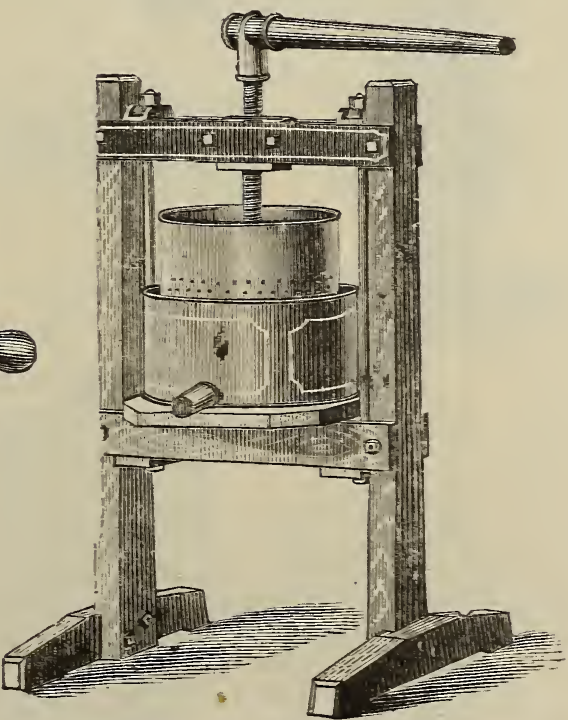

IAMIT CIDER MILLS- $\$ 10.00$. 


\section{FARM SUPPLIES-Continued.}
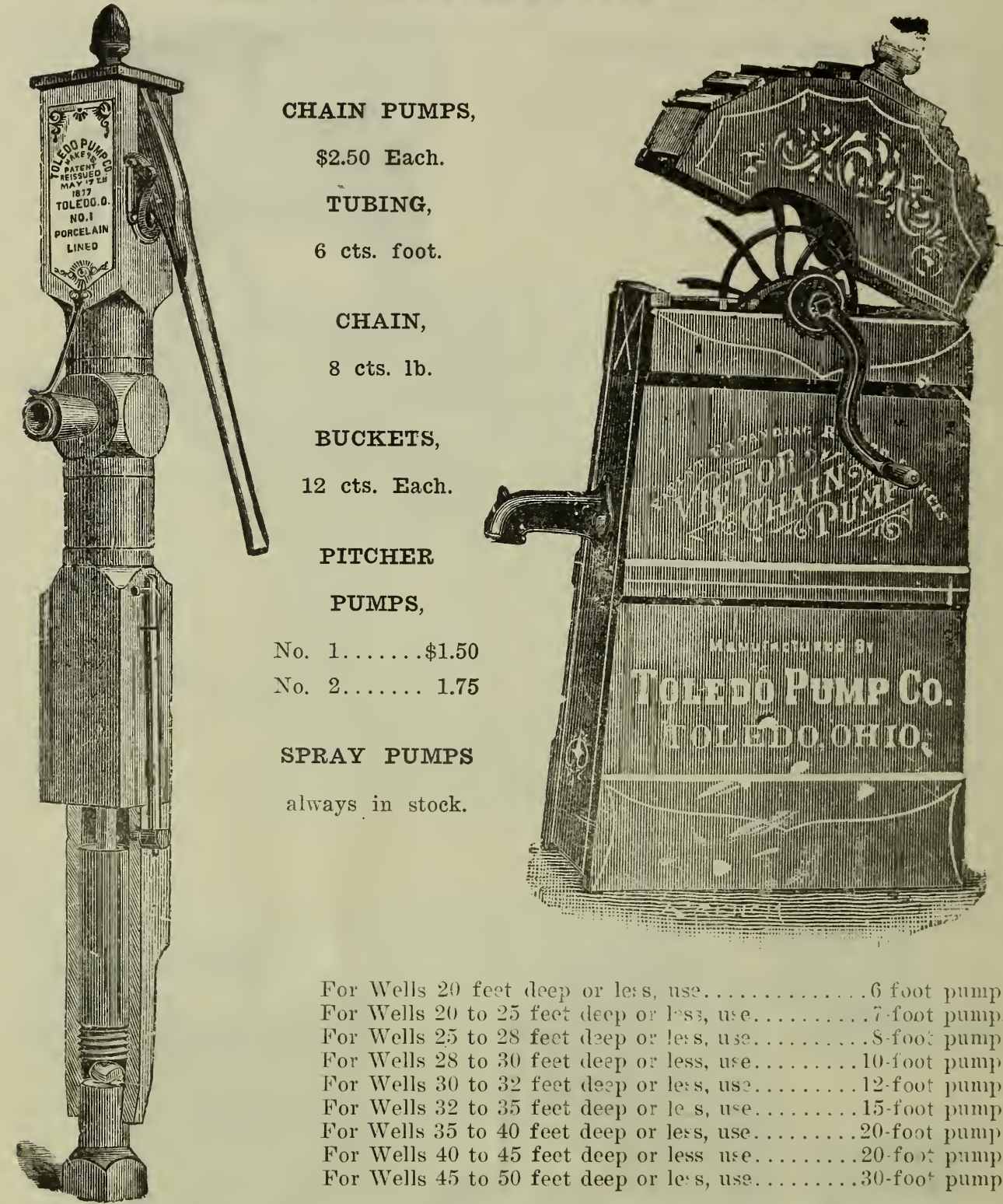

For Wells 20 feet deep or les s, $11 \mathrm{~s}^{2} \ldots \ldots \ldots \ldots \ldots$ foot pump. For Wells 20 to 25 feet decp or l-s; us........ iffoot pump. For Wells 25 to 28 feet drep o: les s, use........ S foo: pump. For Wells 28 to 30 feet deep o: less, use........ lo-foot pump. For Wells 30 to 32 feet deep or le:s, us?.......12-foot pump. For Wells 32 to 35 feet deep or le s, uce........ 15-foot pump. For Wells 35 to 40 feet deep or less, use.......20-foot pump. For Wells 40 to 45 feet deep or less 11 e.........20 fots pump. For Wells 45 to 50 feet deep or le: s, use.........30-foo pump.

No. 1 PIPE, $4 x 4$ INCHES SQUARE, FOR No. 1 AND No. 0 PUMPS.

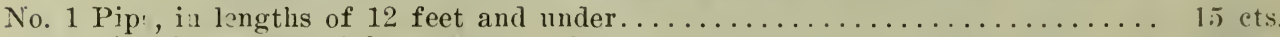

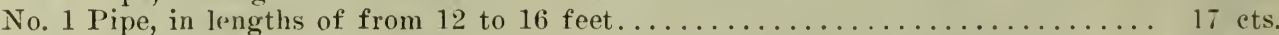

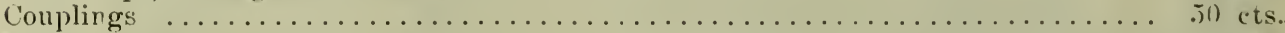

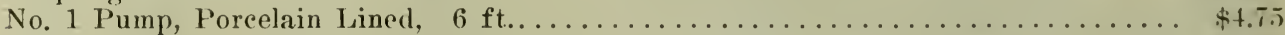

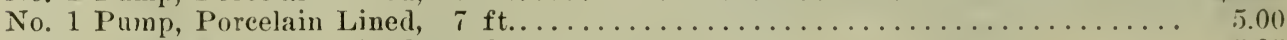

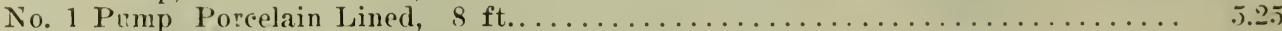

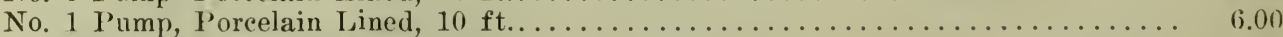

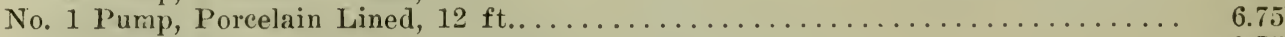

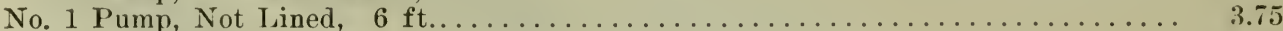

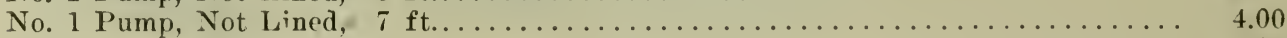

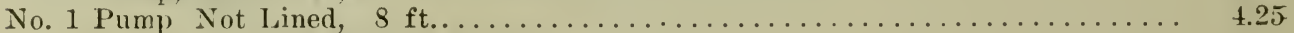

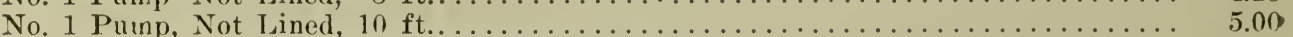




\section{FARM SUPPLIES-Continued.}

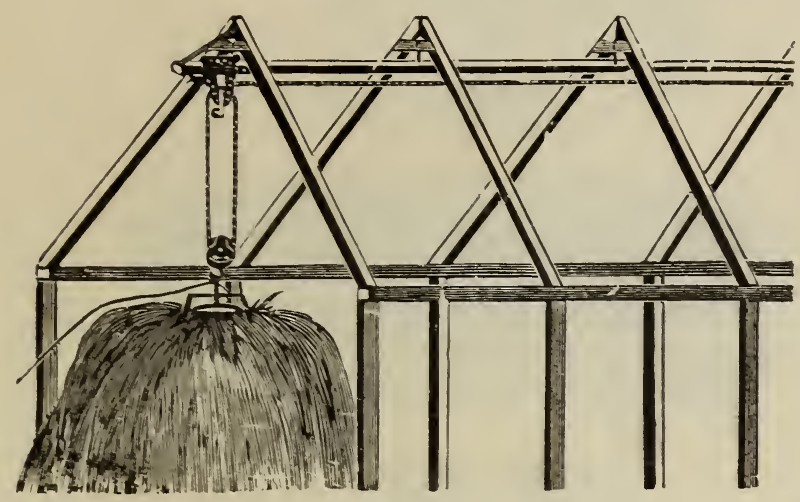

PORTER STEEL TRACK HAY CARS, $\$ 4.50$.

Track, per foot........12 cts.

Floor Hooks...........10 ets.

Brackets, dozen.......65 cts.

Couplings ..........25 cts.

Bumper ...........25 cts.

Stops .............50 ets

Harpoon Hay Fork.......\$1.25

Grapple Hay Fork....... 5.00

Hay Pulleys . . ..25 cts. to $\$ 1.00$

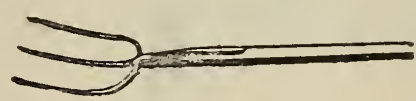

Har Forks ....25 cts. to $70 \mathrm{cts}$.

Manure Forks....65 ets. to $\$ 1.00$
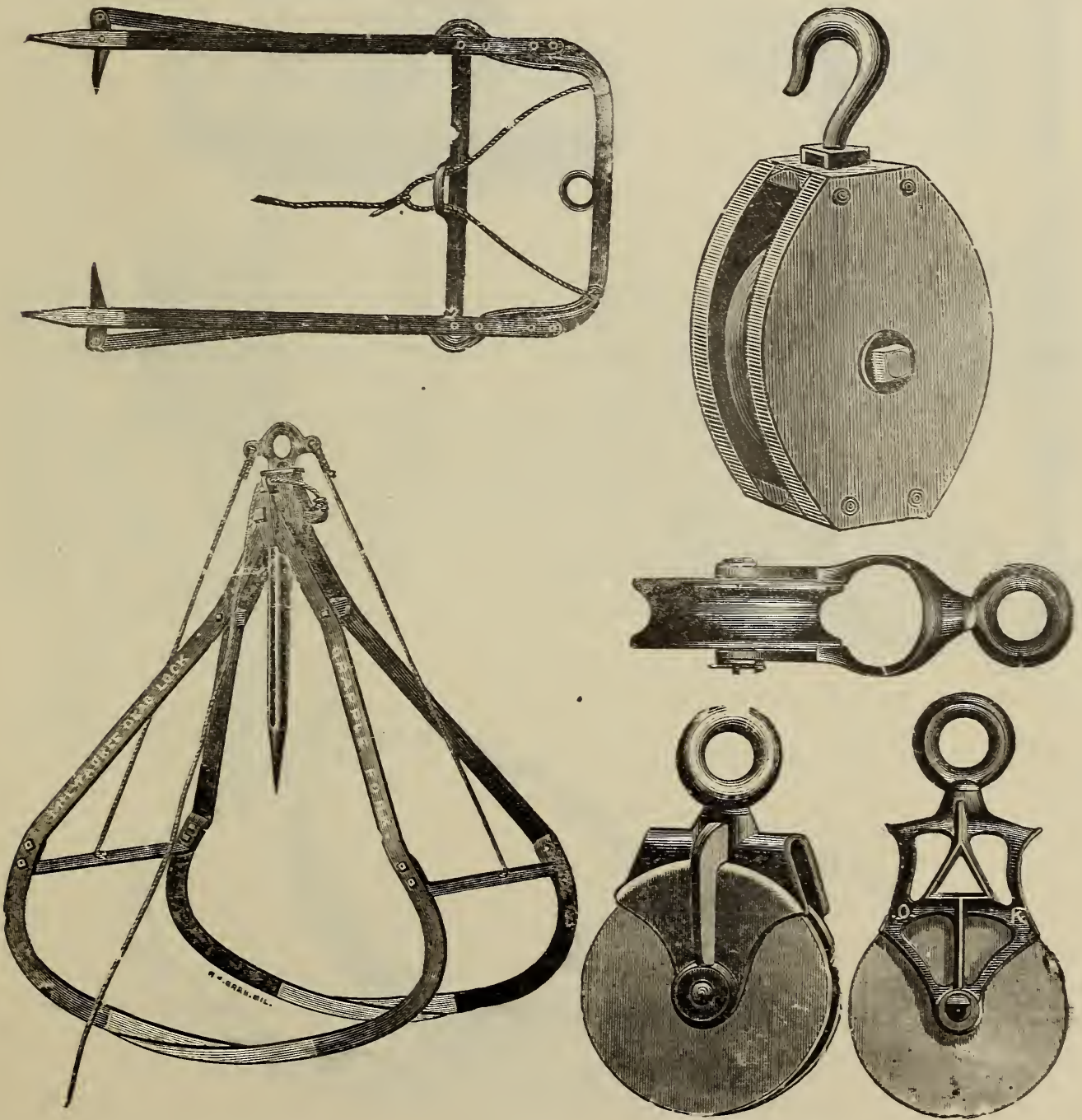


\section{FARM SUPPLIES-Continued.}
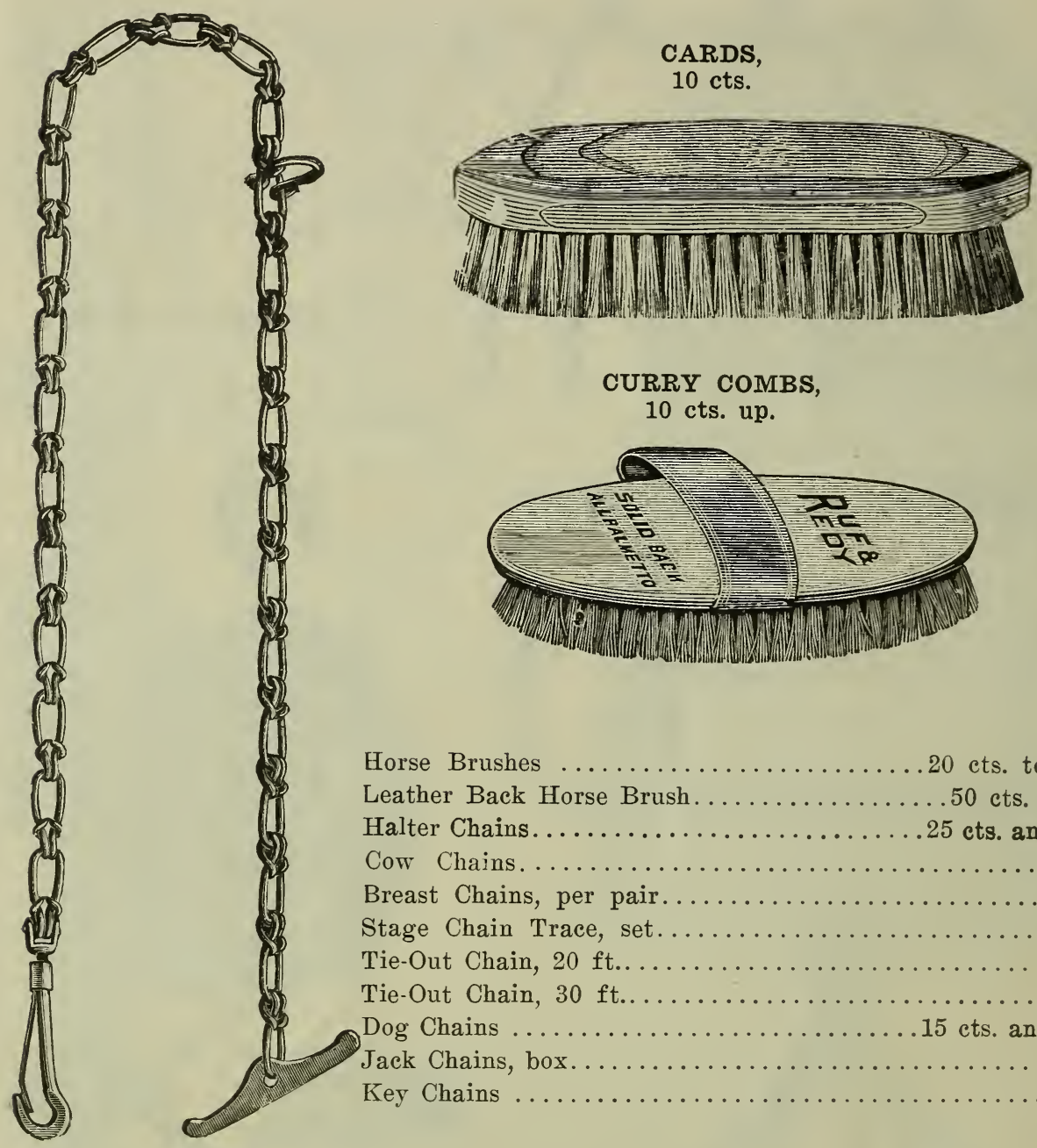

CURRY COMBS,

10 cts. up.

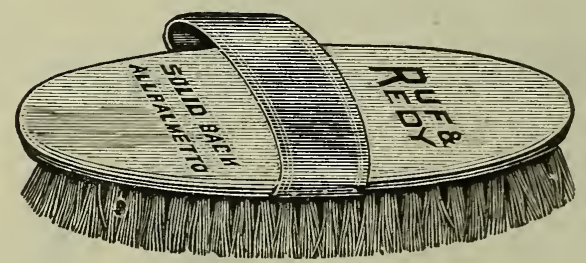

Horse Brushes ................................ to 50 cts.

Leather Back Horse Brush.............50 cts. to $\$ 3.00$

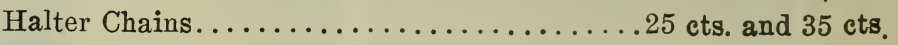

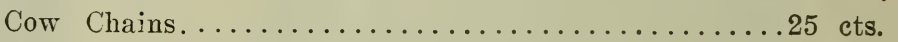

Breast Chains, per pair................60 cts.

Stage Chain Trace, set.................. \$1.20

Tie-Out Chain, $20 \mathrm{ft} . \ldots \ldots \ldots \ldots \ldots \ldots \ldots$ cts.

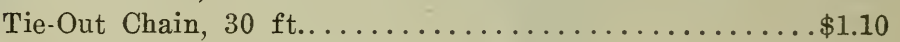

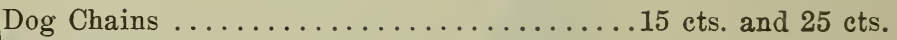

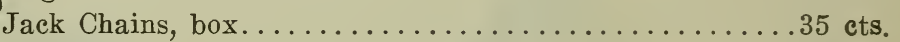

Key Chains ..........................

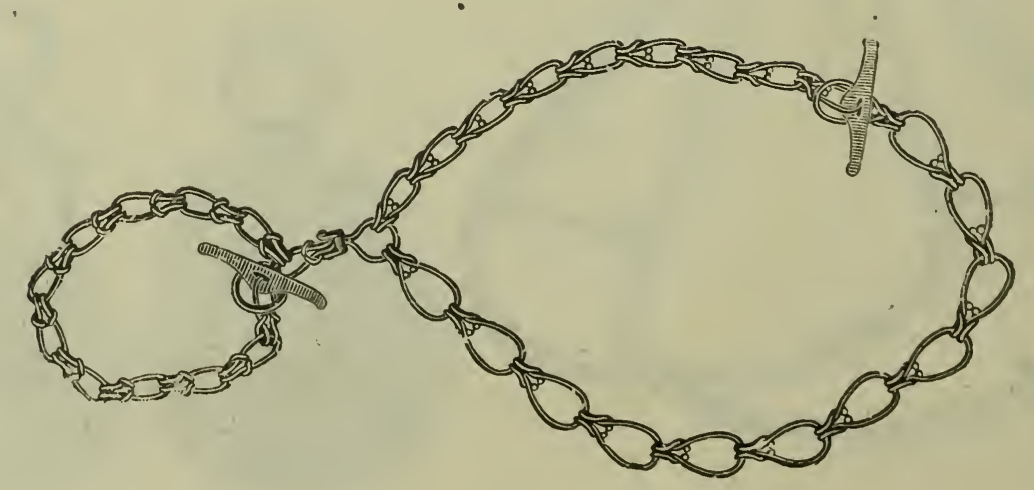




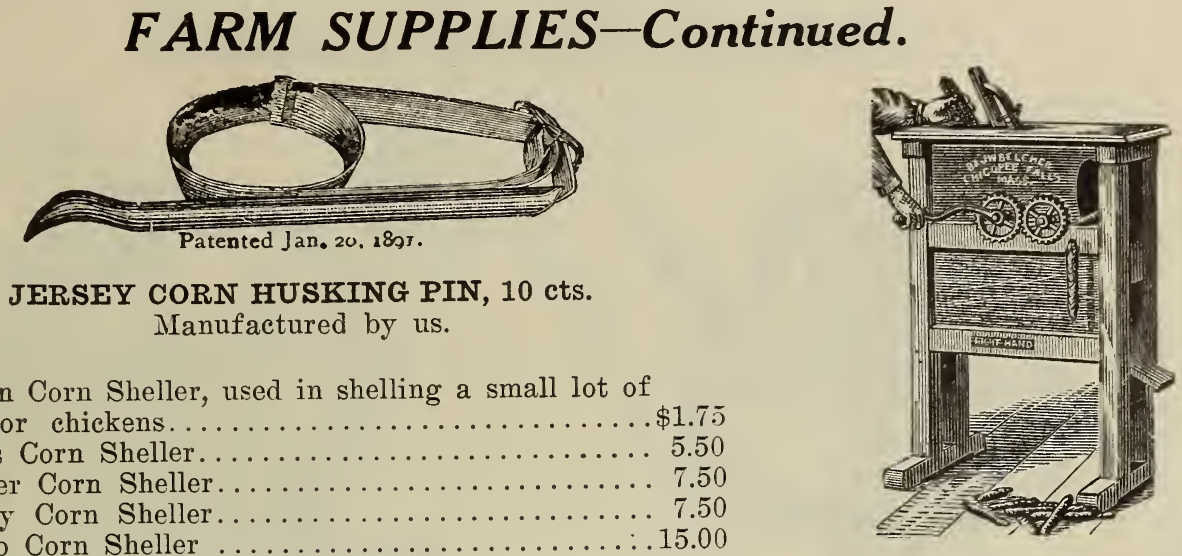

Perfection Corn Sheller, used in shelling a small lot of

corn for chickens.

The Boss Corn Sheller.................... 5.50

The Rover Corn Sheller....................... 7.50

The Pony Corn Sheller.................... 7.50

The Hero Corn Sheller .................... 15.00

The Hero Roller-bearing Sheller............... 16.00

This Sheller cannot be clogged.
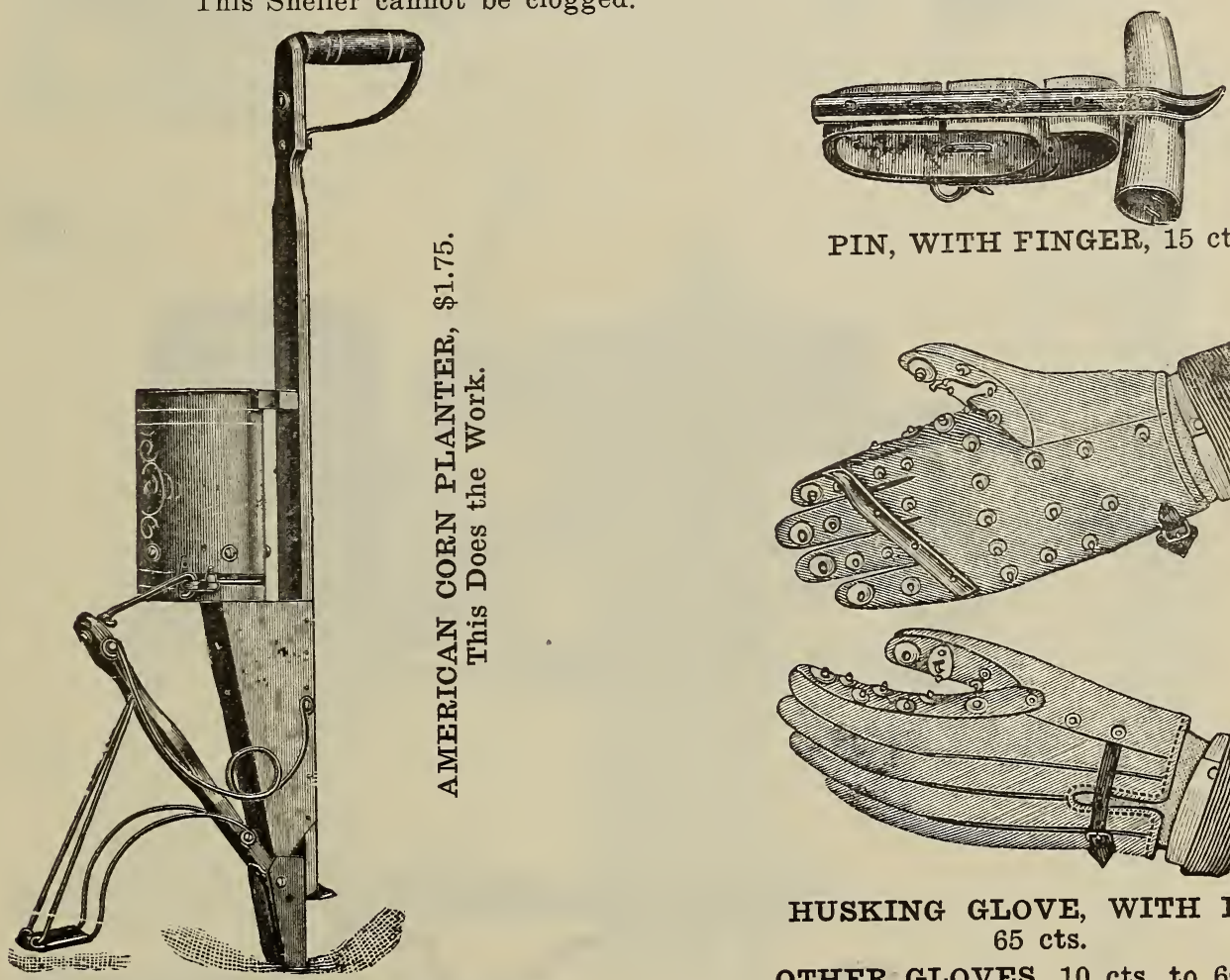

PIN, WITH FINGER, 15 cts.

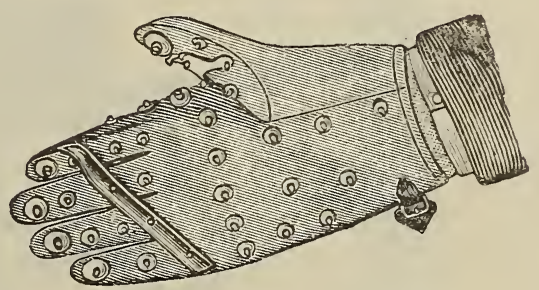

,

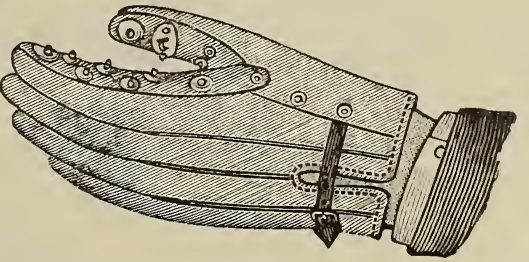

HUSKING GLOVE, WITH PIN, $65 \mathrm{cts}$.

OTHER GLOVES, $10 \mathrm{cts}$. to $60 \mathrm{cts}$.

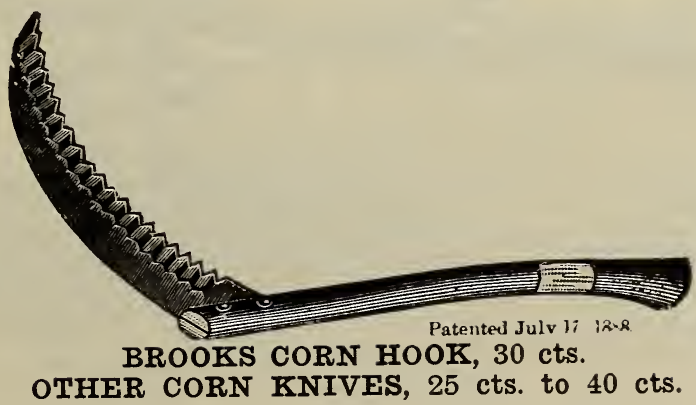




\section{FARM SUPPLIES-Continued.}

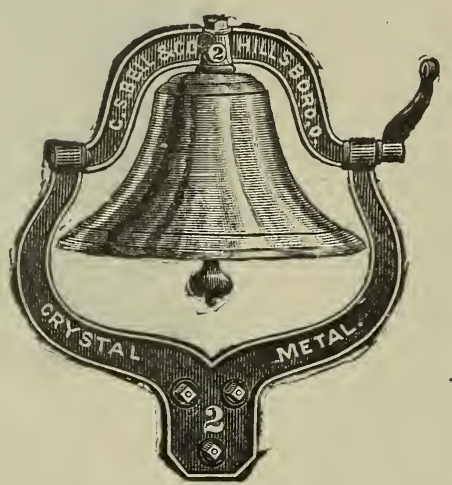

No. 1, Bronzed, 40 lbs........... \$3.00

No. 2, Bronzed, 50 lbs............ 3.50

No. 3, Bronzed, 75 lbs........... 4.75

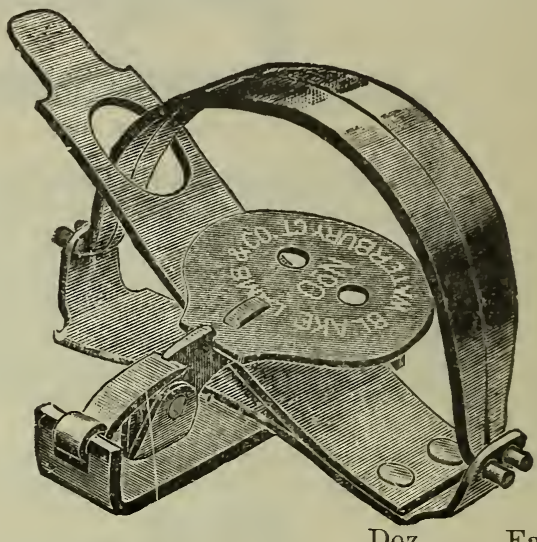

Doz.

No. 0 Blake Trap.......\$1.25

Each.

No. 1 Blake Trap......... $1.35 \quad .15$

5 ets extra with chain.

Oneda Pattern .......... 1.75

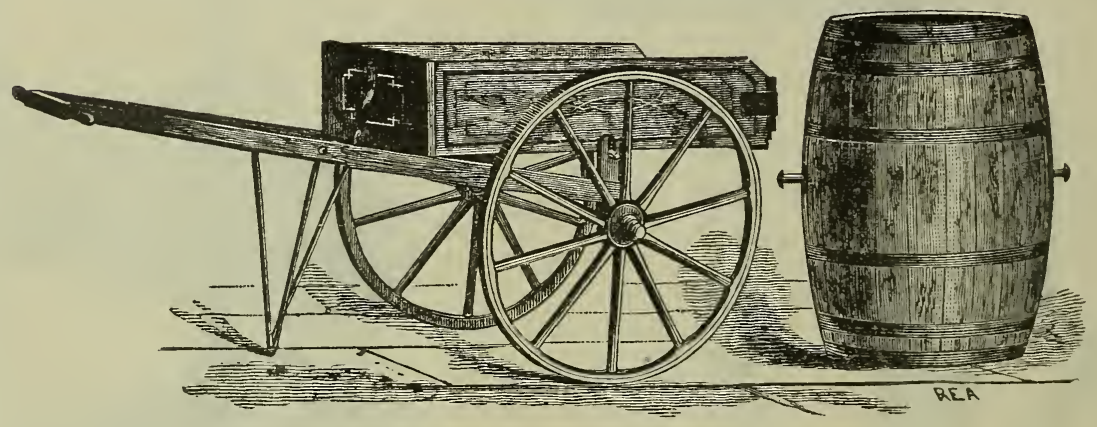

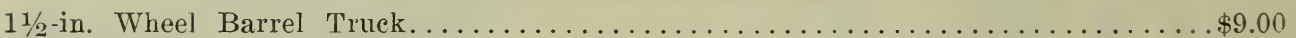

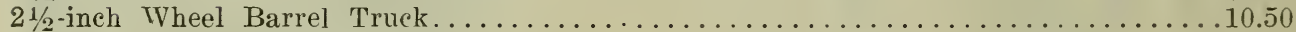
Leaf attachment.

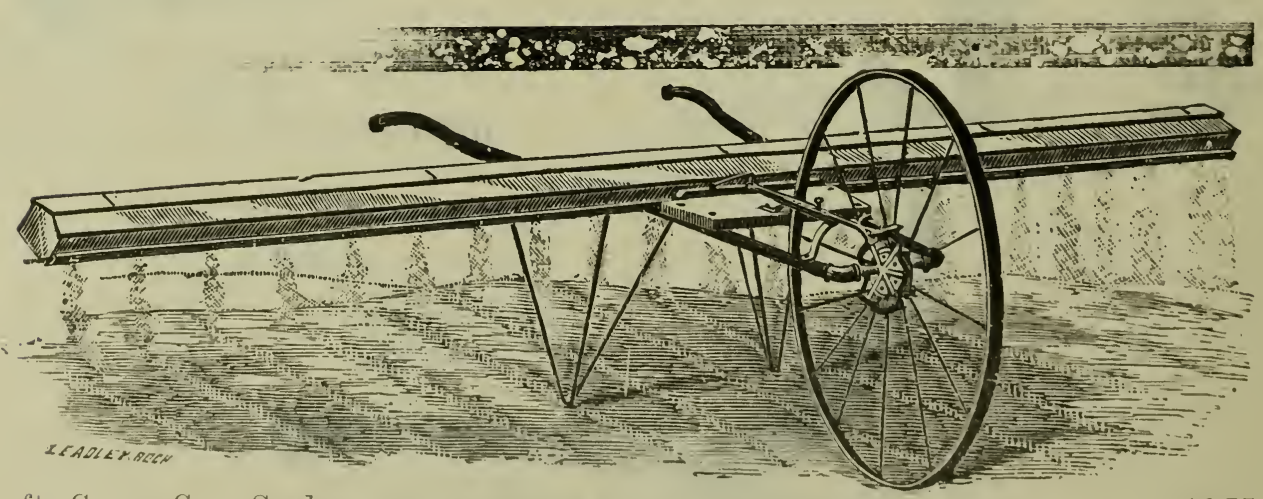

$14 \mathrm{ft}$. Crown Corn Seeder. $\$ 6.75$ 


\section{FARM SUPPLIES-Continued.}

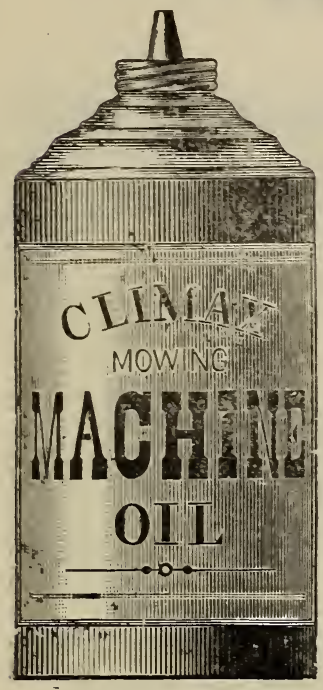

\$3.25 BUYS THE OLD RELIABLE, BEST KNOWN AND TESTED AMERICAN WASHER.
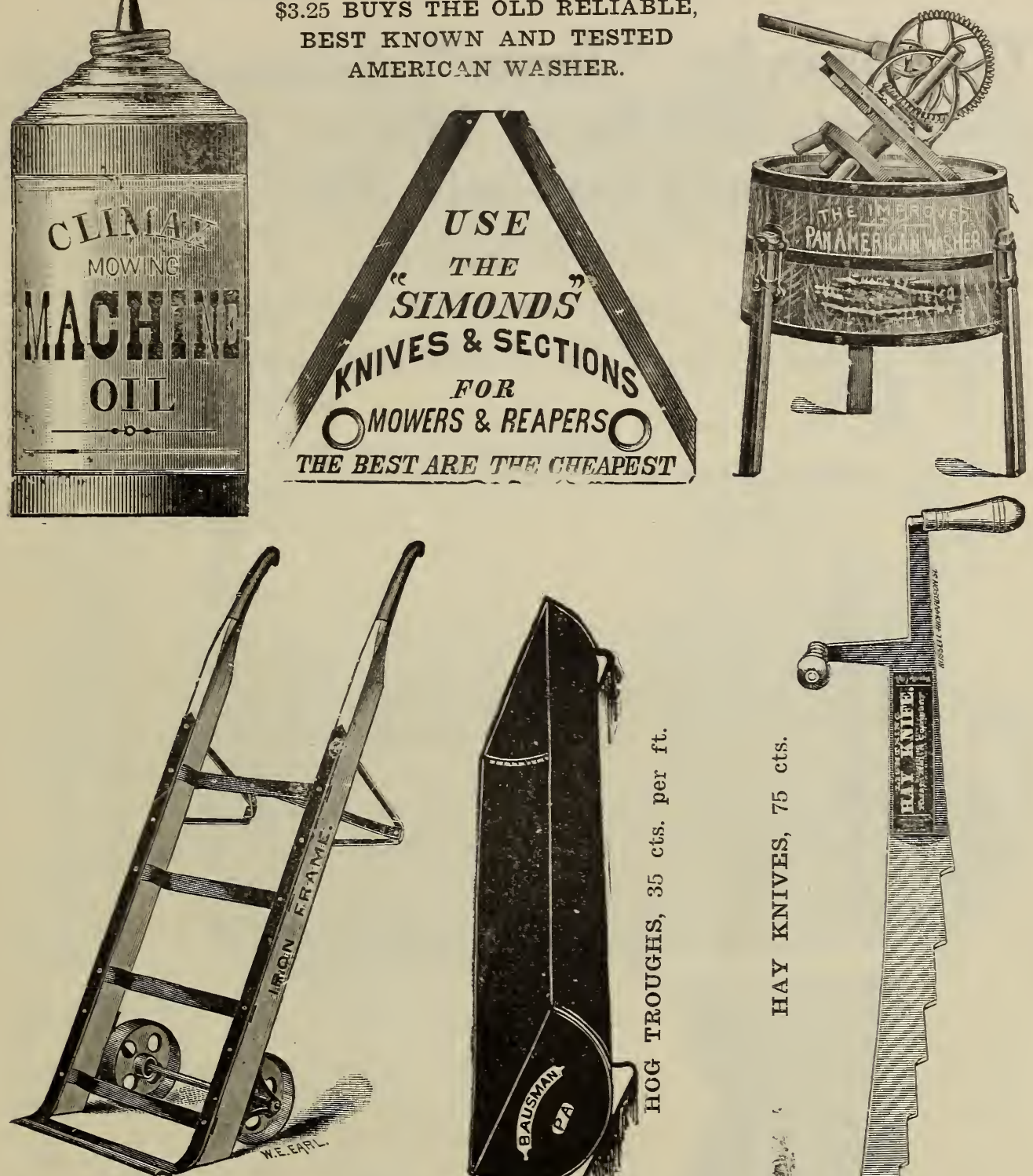

No. 1 Box 1 ruck.......... \$3.75

No. 2 Box Truck........... 4.50

No. 1, 62 bbl. Truck....... 5.50

BAG TRUCK-See Page 48.

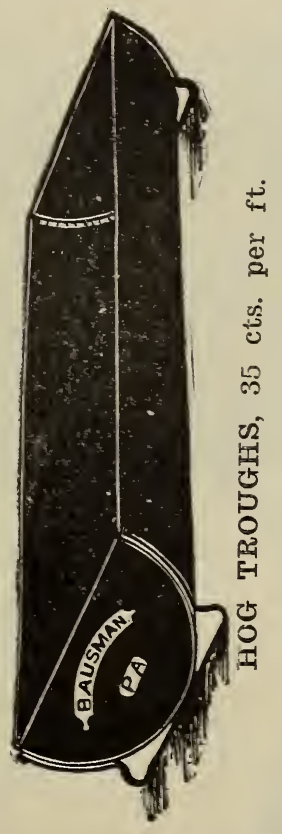

STONE WHEELBARROW, $\$ 3.90$.
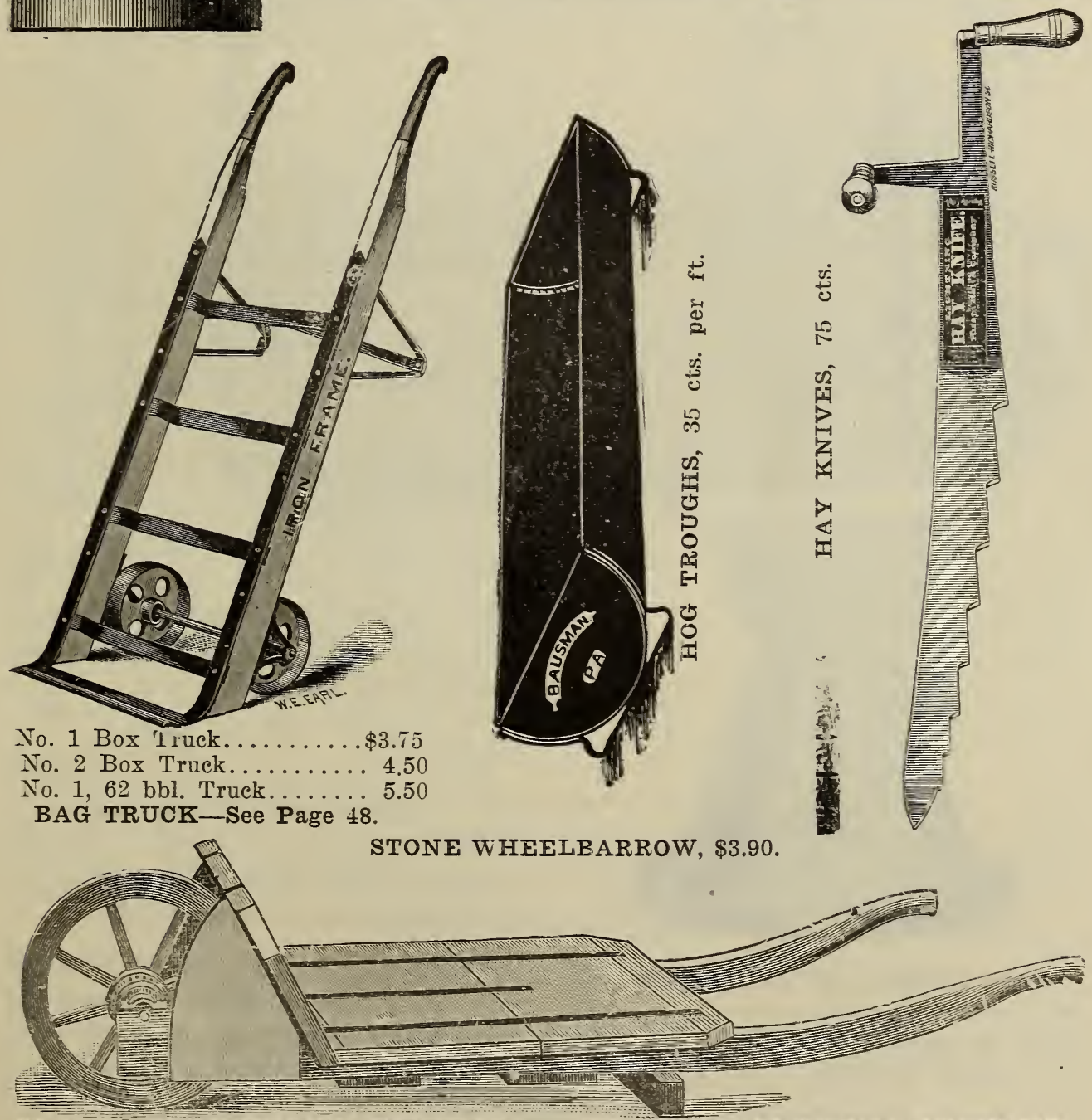


\section{FARM and DAIRY SUPPLIES.}

\section{The Sharples "Jersey" Separator will separate 550 lbs. of Milk in an hour, and cost only $\$ 40$}

COLD OR WARM MILK.

IT IS EASY TO RUN, EASY TO CLEAN, AND GETS ALI THE CREAM.

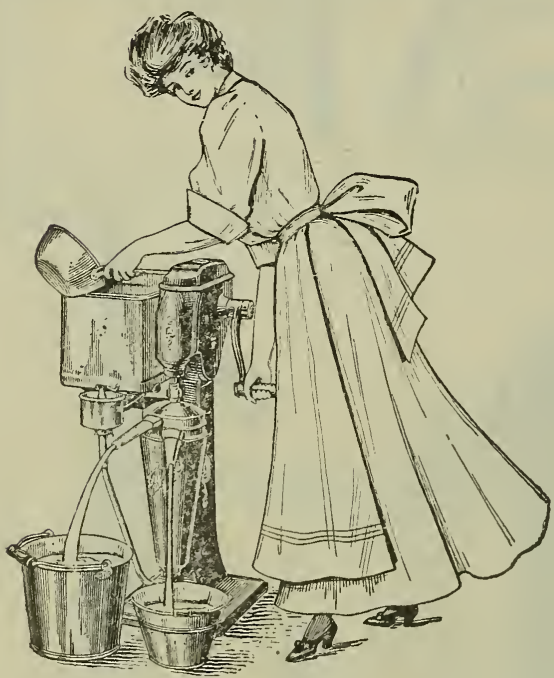

THE TUBULAR, $\$ 40.00$ AND UP.

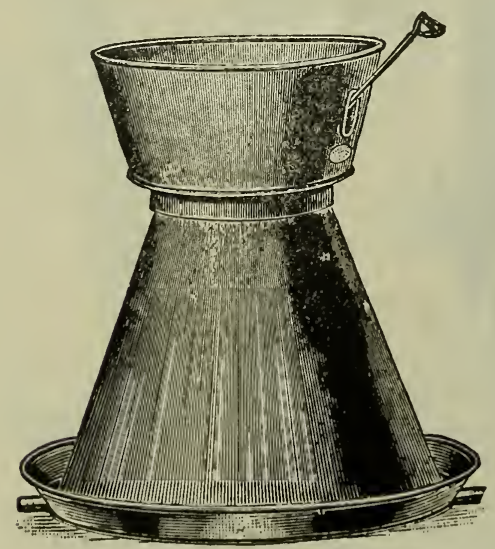

CHAMPION MILK COOLER.

No. 1, 1 to 10 Cows........... $\$ 6.00$

No. 2, 10 to 20 Cows............ 6.00

No. 3,20 to 50 Cows............ 7.00
SHARPLES TUBULAR "A", SEPARATORS.

No. 1.-Capacity, 225 to 250 pounds per hour. Price ........... $\$ 40.00$ No. 2.-Capacity, 300 lbs. per hour.

Price ................. 55.00

No. 3..-Capacity, 400 lbs. per hour.

Price .................6 65.00

No. 4.-Capacity, 500 lbs. per hour.

Price ................ $\$ 75.00$

These sizes are 2 feet 10 inches high; the top of the supply can is two inches lower. Suitable for dairies of 3 to 7 cows.

No. 5.-Capacity, 500 lbs. per hour.

Price .................. \$80.00

No. 7.-Capacity, 700 lbs. per hour.

Price ................... 100.00

No. 10.-Capacity, 1,000 lbs. per hour.

Price ................... 125.00

Three feet five inches high-require very little steam-are the most efficient power separators for dairy use.

No. 6.-Capacity, 700 lbs. per hour.

Price .................... 90.00

No. 9.-Capacity, 950 lbs. per hour.

Price ....................110.00

Three feet six inches high; the top of the supply can is two inches lower.

Sizes, 2, 3, 4, 6 and 9 may be converted into belt driven machines by means of power pulley attachment for $\$ 2.50$ additional; for dairies of $S$ to 30 cows. 


\section{FARM and DAIRY SUPPLIES-Continued.}

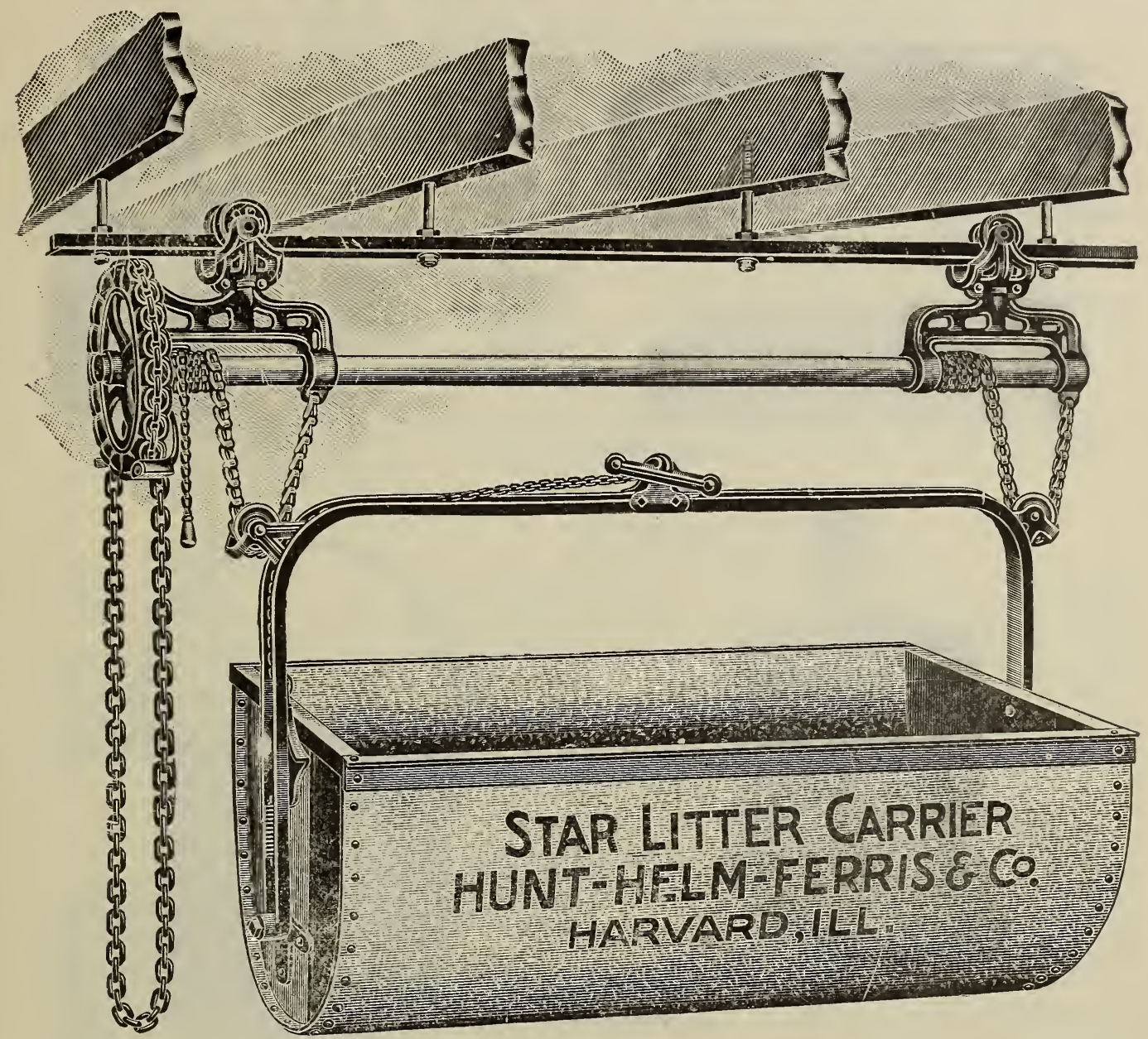

CARRIER-This Carrier is constructed of heavy malleable iron. Two swivel trucks are fitted with two tracker wheels each, which give the Carrier a double tread on the track. These tracker wheels run on hardened steel axles. To each of the swivel trucks is attached a supporting bracket in which revolves the horizontal shaft on which the supporting chain winds. In other makes of Litter Carriers the shaft is supported at but two points, while the shaft of this Carrier is supported at four points. The shaft support at each end is 11 jnches wide and spans the portion of the $13-8$ inch shaft on which the chain winds and where the strain of the lift comes. Complete length of the shaft is 60 inches.

Track with extras for hanging, 15 cents per foot.

Tubs are furnished in three sizes as follows, outside dimensions:

No. 2-26 inches wide, 41 inches long, 14 inches deep, weight 40 lbs............ $\$ 21.00$

No. 4-26 inches wide, 41 inches long, 17 inches deep, weight 45 lbs............ 22.10

No. ij-26 inches wide, 41 inches long, 19 inches deep, weight 50 lbs . . . . . . 24.00

ive will give price placed in your barn.

IRON CLAD IMILK CANS.

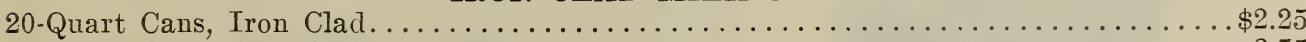

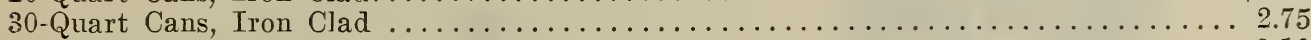

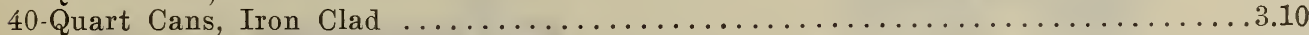

We mark the cans with your name on lid and can. We do our own marking; 25 cents per can. Ask for special prices in quantity. Skim milk labels that comply with the law, 35 cents.

Ask for samples of Warrenoid Roofing; manufactured especially for us. 


\section{FARM and DAIRY SUPPLIES-Continued.}

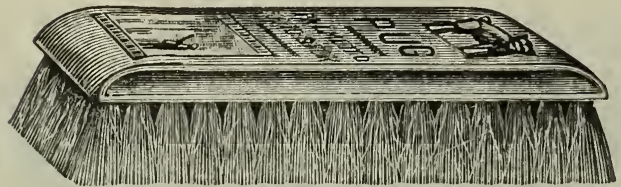

DAIRY SCRUB BRUSH, 20 cts. to 35 icts. 18-INCH HAND CAN BRUSH, $50 \mathrm{cts.}$

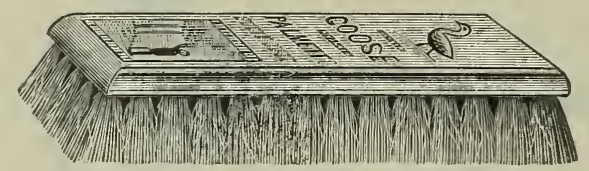

MILK JAR BRUSHES, $25 \mathrm{cts}$. to $35 \mathrm{cts}$.

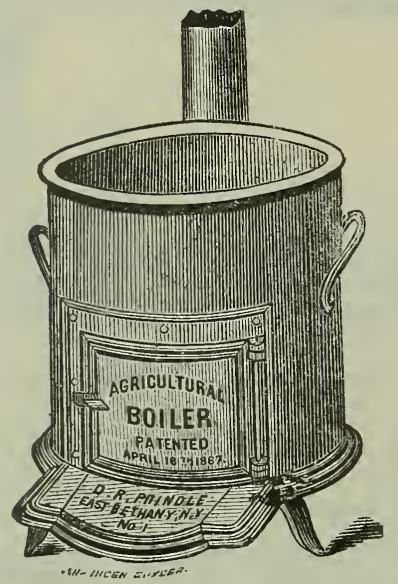

15 gal. Farm Boiler for Wood.....\$13.25

22 gal. Farm Boiler for Wood...... 16.50

30 gal. Farm B,jier fo: Wood...... 22.00

45 gal. Farm Bui.er for Wood...... 27.00

60 gal. Farm Boiler for Wood...... 33.00

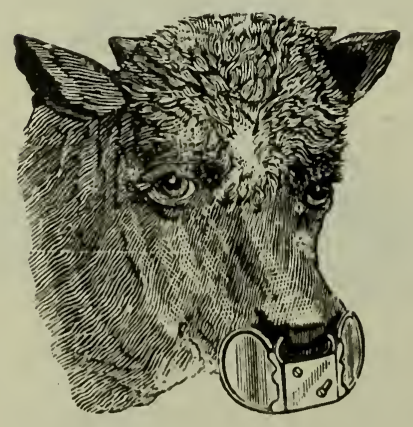

RICE COW WEANER.

Calf, 30e.; Heifer, 40c.; Cow, 60c.
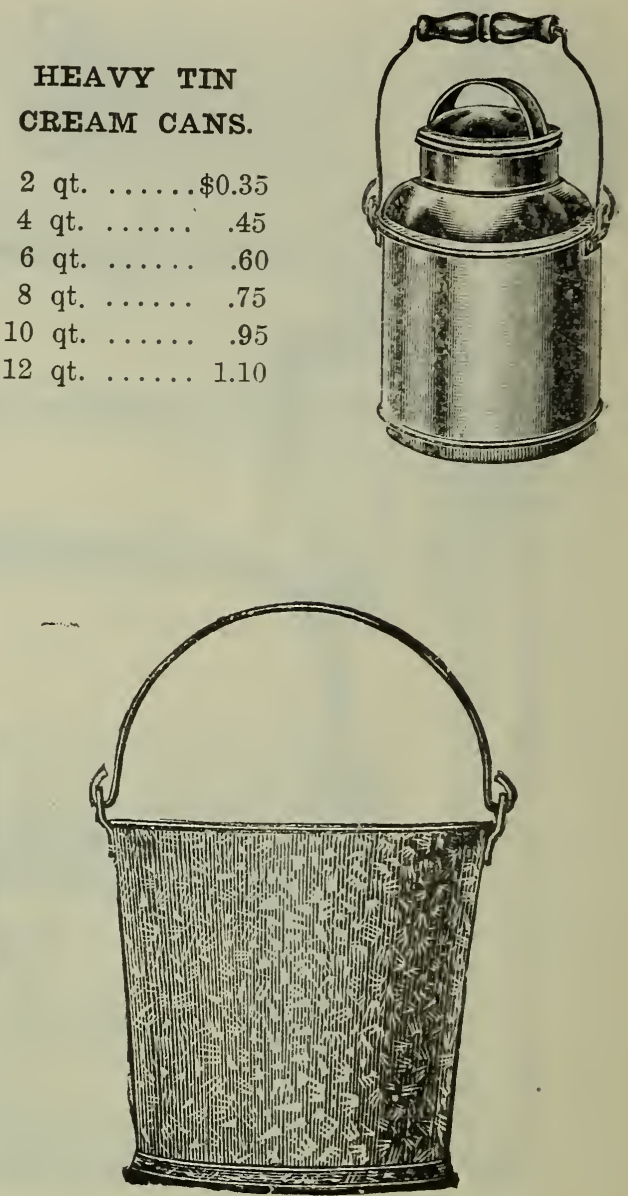

Tin Pails ...............35c. and 45c. Iron Clad Pails, Tin........40c. to 60.c Galvanized Pail, 10-Qt. 20c., 12 Qt. 25c., 14 Qt. 30c., 16 Qt. 35c.

Lish, extra heary, red band, 14 qt., gal. pail-40c.

Cream Pails ..............25c. to $\$ 1.10$

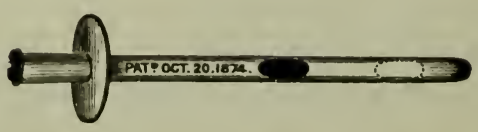

Milking Tubes ..............25c. 


\section{FARM and DAIRY SUPPLIES-Continued.}

\section{DAVIS SWING CHURN, COMPLETE WITH FOLDING FRAME AS SHOWN.}

This is the regular frame, and is always sent unless specially ordered otherwise. Tilting Frame $\$ 1.00$ extra.

\begin{tabular}{|c|c|c|c|c|}
\hline & & & & $r \mathrm{Y}$ and \\
\hline Size. & Till Churn. & Capacity. & Price. & pitman. \\
\hline No. 1 & 4 gallons or less & 8 gallons & $\$ 8.00$ & $\$ 0.75$ \\
\hline No. & 5 gallons or less & 10 gallons & 9.00 & .75 \\
\hline No. & S gallons or less & 16 gallons & 10.00 & .75 \\
\hline No. & 10 gallons or less & 20 gallons & 12.00 & .75 \\
\hline No. & 13 gallons or less & 26 gallons & 15.00 & 1.00 \\
\hline No. 6 & 17 gallons or less & 34 gallons & & 1.00 \\
\hline No. $\div$ & 30 gallons or less & 60 gallons & 25.00 & 1.25 \\
\hline
\end{tabular}

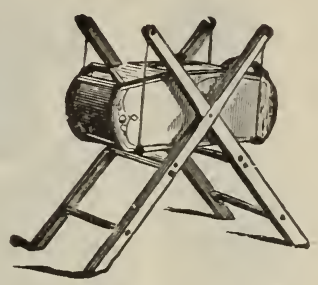

Puller, 12x3, and attachments........\$4.00 extra.

Tight and loose pulley, $12 \times 3$, and attachments, 5.50 extra.

*Power attachment for No. 7 , in large square frame, with $18 \times 4$ tight and loose pulleys $\$ 10.00$.

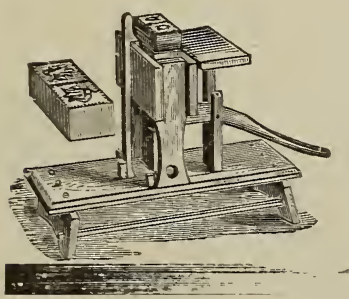

Everything for Dairymen. REED BUTTER PRINTER.

For one-half pound Printer................ \$10,00

For pound Printer .............................. 100

For both pound and half pound Printer, combined........ 13.50

For tro-pound Printer......................... 11.00

$\$ 1.00$ extra for initials or monogram.

\section{COOLER CREAMER.}

Ask for prices and circulars. Cooler Creamer Cans, $\$ 2.75$.
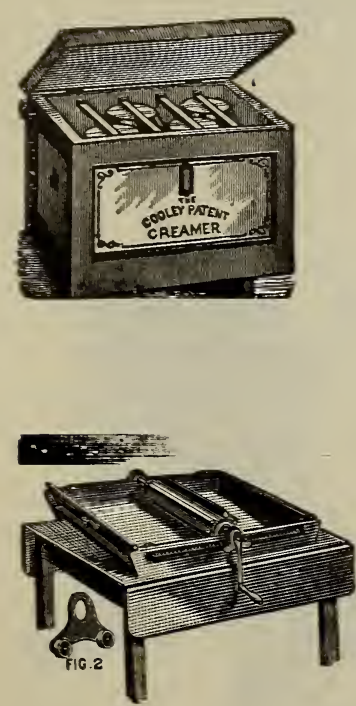

\section{SKIMIMER BUTTER WORKER.}

Ask for circulars.

\section{EUREKA BUTTER WORKER.}

Roll is cone-shaped with shallow fluting, which avoids all injury to grain of butter.

No lost motion; butter worked either side of roller. Has positire adjustment of roller to accommodate hard or soft butter.

No. 1-Family

No. 4-Factory

\begin{tabular}{lr}
\multicolumn{1}{c}{ Sizes. } & Capacity. \\
No. 1-Family & 8 to $12 \mathrm{lbs}$. \\
No. 2-Dairy & 10 to $20 \mathrm{lbs}$. \\
No. 3-Dairy & 20 to $40 \mathrm{lbs}$. \\
No. 4-Factory & 40 to $60 \mathrm{lbs}$.
\end{tabular}

40 to 60 lbs.
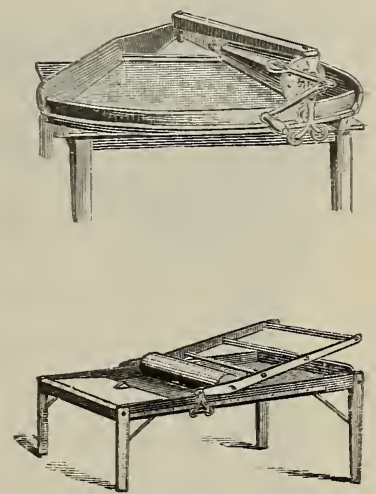

They are easily folded into small compass. Nos. 3 and 4 have stiff legs, thoroughly braced.

\section{BUTTER WORKER PRICE IIST.}

No. $1-$ Size $23 \times 36$ in. and $21 \frac{\text { Capacity. Weight. }}{\text { in. deep inside.........50 lbs.....45 lbs..... } \$ 10.00}$

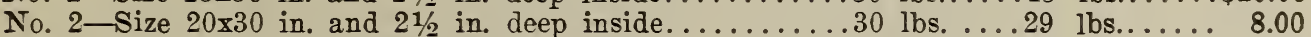

No. 3 -Size $17 \times 27$ in. and $21 \frac{1}{2}$ in. deep inside...........20 lbs....25 lbs..... 7.00

No. 4 -Size $14 \times 23$ in. and $2 \frac{1}{2}$ in. deep inside.......... 


\section{FARM and DAIRY SUPPLIES-Continued.}

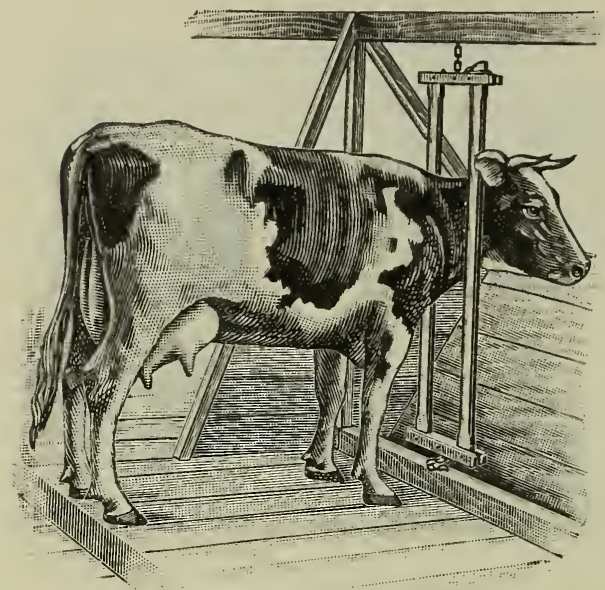

\section{ROBERTSON'S CHAIN HANGING \\ STANCHIONS ARE PRACTICAL, SAFE AND DURABLE.}

Will afford Comfort to the Animal.

Made with either rigid or adjustable neck space.

Wood Cow Stanchions...........\$1.25

Steel Cow Stanchions ............... 1.75

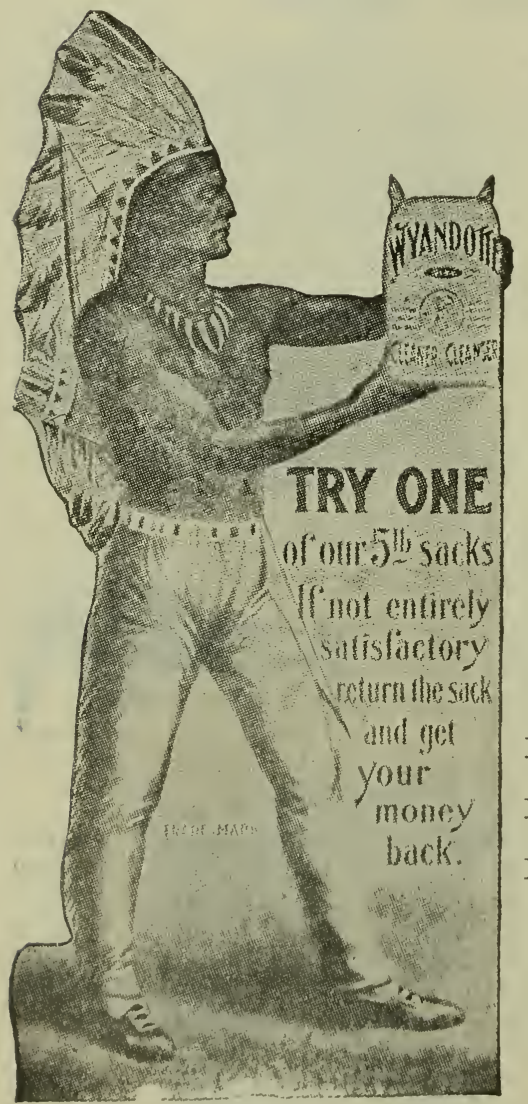

Wyandotte per $5 \mathrm{lb}$. bag.............. \$0.25

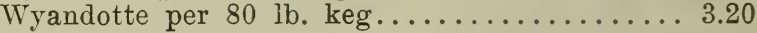

Wyandotte per $280 \mathrm{lb}$ bbl.............. 8.40

THE HERO CHURN.

No. 1,10 gals....... $\$ 3.50$

No. 2, 15 gals....... 4.25

No. 3, 20 gals....... 4.75

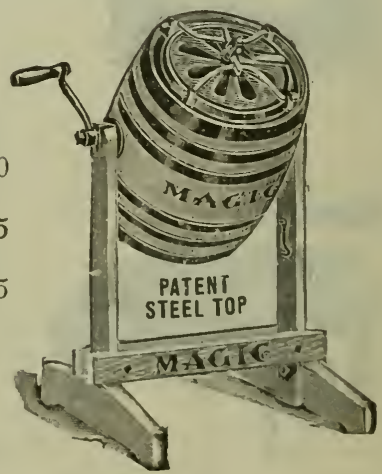

Pulley Wheels Extra.

OW CUPS.

\section{YOUR MONEY BACK.}

Get a sack of WYANDOTTE DAIRYMAN'S CLEANER and CLEANSER-use all of it-and if it is not perfectly atisfactory-return the empty sack to your dealer and he will refunà you your money. 


\section{FARM and DAIRY SUPPLIES-Continued.}

FOR DAIRY SUPPLIES Go to SATTERTHWAITE'S.

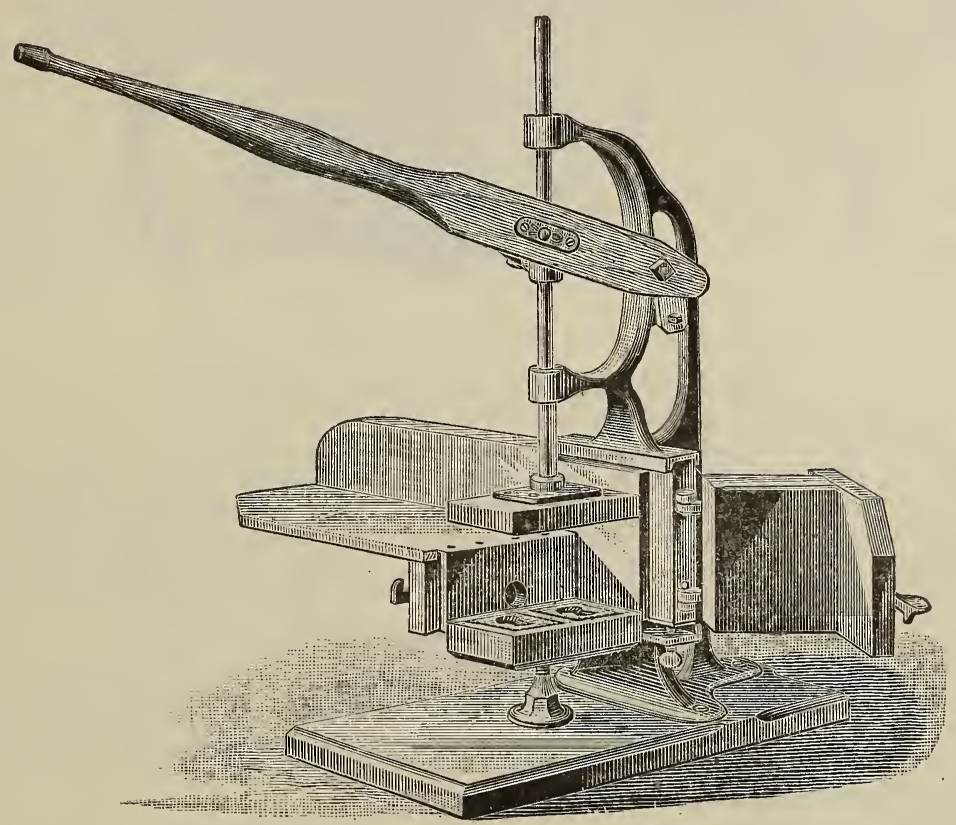

REID'S SELF-GAUGING BUTTER PRINTER.

Reid's Self-Gauging Butter Printer not only prints very neatly and quickly, but also gauges the butter into pounds or half pounds. It does the work in one quarter the time and makes the prints neater. This printer is the most popular on the market.

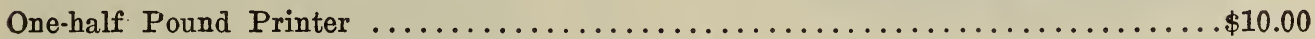

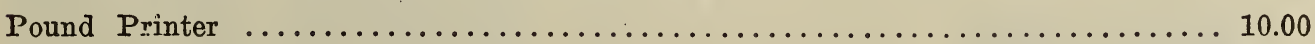

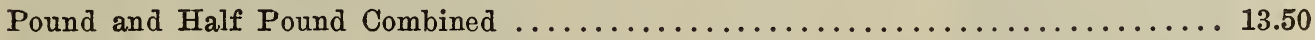

\section{SATTERTHWAITE'S WARRENOID ROOFING}

Guaranteed ten years if coated twice with paint. 


\section{FARM and DAIRY SUPPLIES-Continued.}

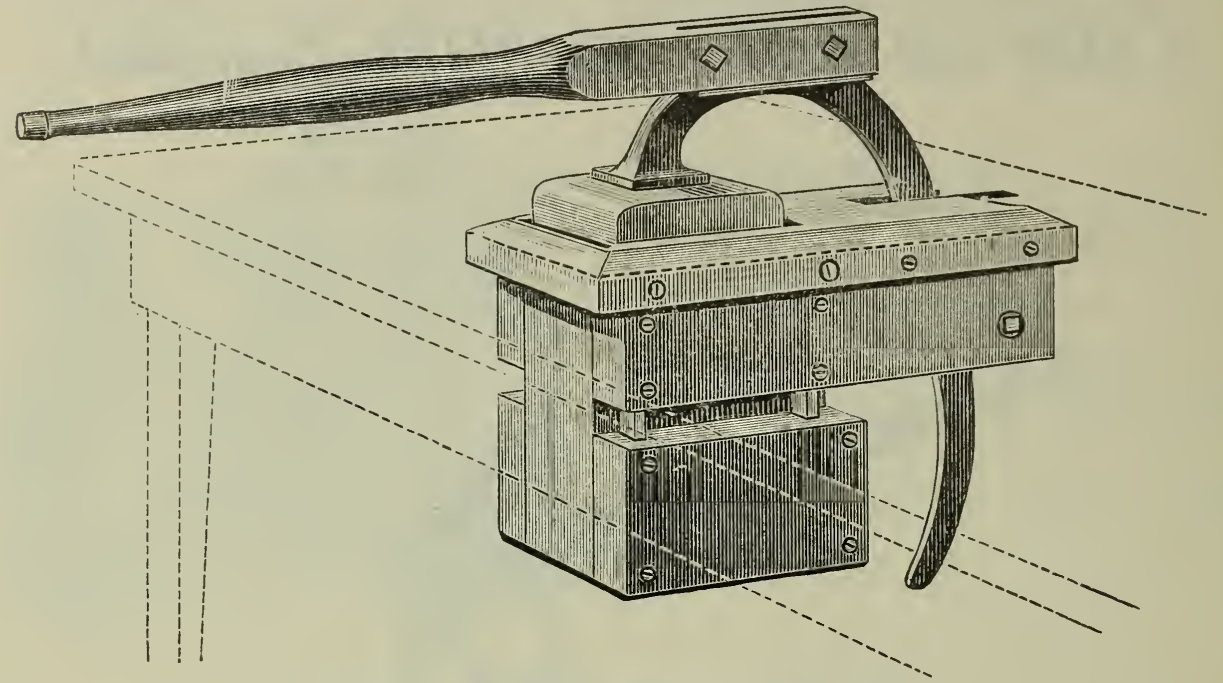

THE IAFAYETTE BUTTER PRINTER.

This printer is self-gauging and is intended for use in creameries, but more especially for reprinting butter. It is very rapid and does excellent work.

To operate, fill the box, which is on a level with top of table, with butter working it in solid using the lever then stroke it off level with a paddle then raise the lever and throw it all the way back, which raises the butter out of the box nicely printed.

There are screws in the bottom of the print block, and also in the bottom of the follower, for adjusting the weight of the butter.

\section{SIZES AND PRICES.}

For either pound or half-pound printer, without table................. $\$ 10.00$

For eithe $i$ pound or half-pound printer, with table, complete.............. 15.00

F'or two-pound printer, without table.................................. 13.00

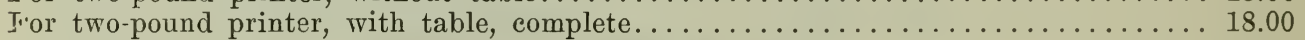

For carving monograms or initials on print blocks..................... 1.00
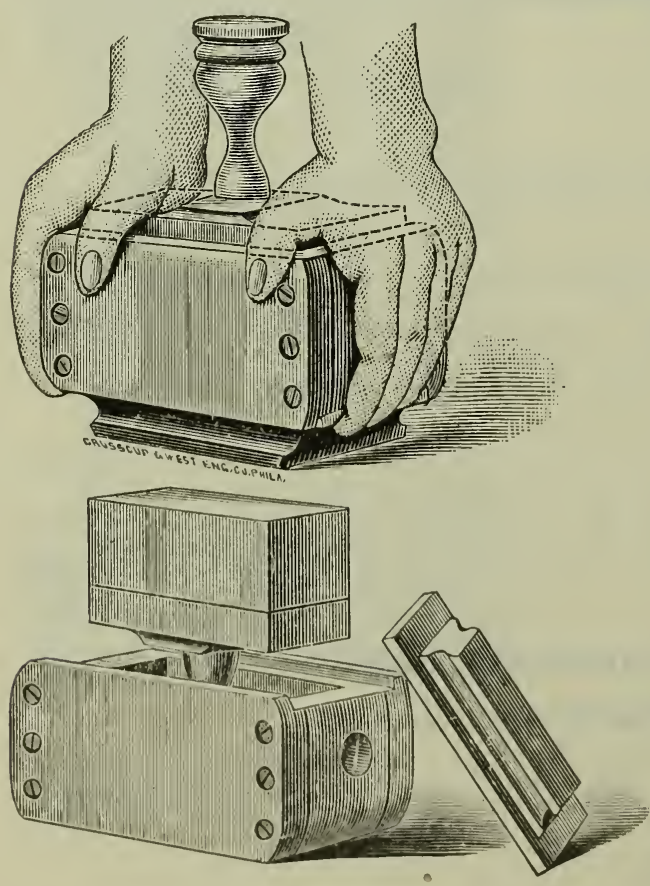

Unless otherwise ordered, tables are not sent with printers.

\section{REID'S HAND BUTTER MOLD.}

Fig. 1 represents the butter in the mold and the hands of the operator in the act of pressing.

Fig. 2 shows the butter molded on the print ready to be taken and turned on to a tray or elsewhere, when it will show the printed face.

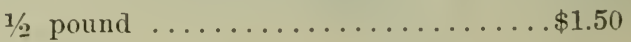

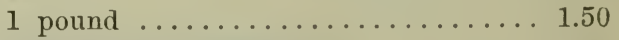

2 pounds ................. 2.50

Special hand lb. print........... .75 


\section{FARM AND DAIRY SUPPLIES-Continued.}

CAN AND MILK FILLERS, BOTTLE

\section{WASHING MACHINERY, SANITARY}

\section{DELIVERY CASES.}

If You Want the Best, Investigate the Merits of the R. \& A. Line.

Illustration shows R. \& A. Bottle Filler No. 2Equipped with erank lifting derice and R. \& A. Nonoverflow Valres. Fills 4 quarts atone end and 5 pints at the other.

Intended especially for the up-to-date milk man with a prosperous business.

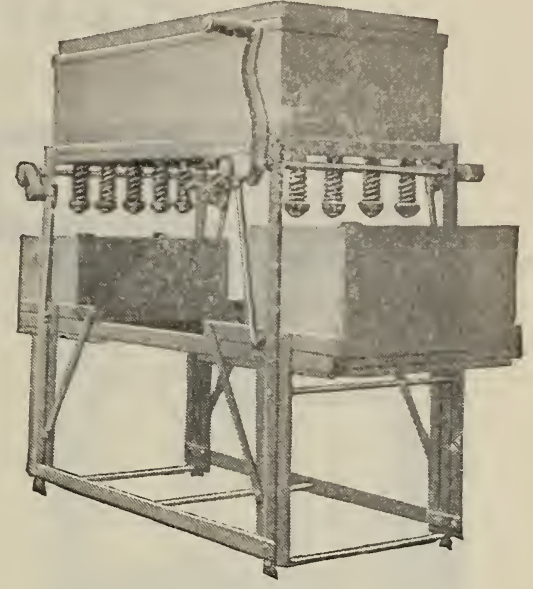

PRICE LIST OF BOTTLE FILLERS.

H.

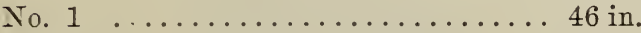

${ }^{*}$ No. $2 \ldots \ldots \ldots \ldots \ldots \ldots \ldots \ldots \ldots$. 49 in.

zNo. $2 \ldots \ldots \ldots \ldots \ldots \ldots \ldots \ldots \ldots$ in.

zNo. $4 \ldots \ldots \ldots \ldots \ldots \ldots \ldots \ldots \ldots \ldots$ in.

zNo. $5 \ldots \ldots \ldots \ldots \ldots \ldots \ldots \ldots$ in.

No. $6 \ldots \ldots \ldots \ldots \ldots \ldots \ldots$ in.

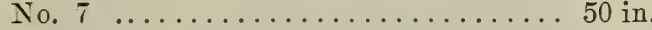

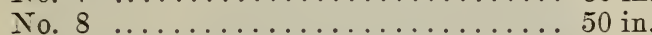

* Tin tank with copper bottom.

z Rust-proof copper tank with brass valre plates.

$\begin{array}{cccr}\text { Cap 'y } & \begin{array}{c}\text { Tank } \\ \text { Cap. }\end{array} & \begin{array}{c}\text { Ship } \\ \text { Wt. }\end{array} & \text { Price. } \\ \text { Per. Hr. } & \text { Gal. } & \text { Wt. } & \$ 50.00 \\ 1,000 & 30 & 200 & 75.00 \\ 3,000 & 40 & 200 & 85.00 \\ 3,000 & 40 & 200 & 250.00 \\ 10,000 & 60 & 450 & 150.00 \\ 4,000 & 50 & 350 & 325.00 \\ 10,000 & 70 & 650 & 325.00 \\ 10,000 & 70 & 650 & 325.00 \\ 10,000 & 80 & 650 & \end{array}$

BEST JAR MADE.

Quarter Pint Jars

Five Gross. One Gross.

......

$\$ 4.00$

4.00

$\$ 20.00$

Third Pin乞 Jars

21.50

Pint Jar:

31.25

4.50

5.00

7.00

Doz. $\$ 0.45$

.45

.45

.50

Quart

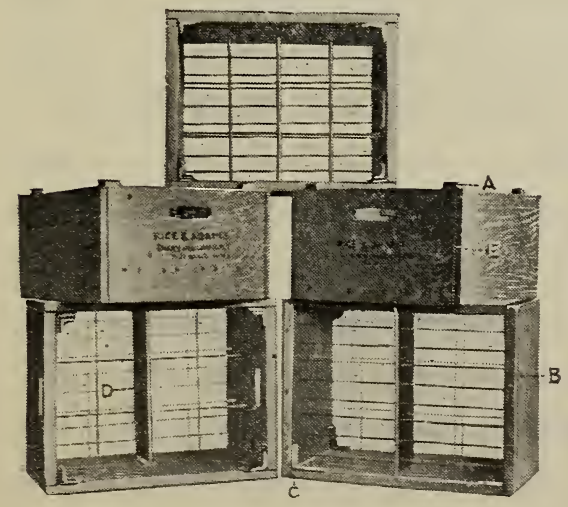

\section{PRICE LIST OF CASES.}

No. of Bottles Capacity per case $\ldots \ldots \ldots \ldots 20 \quad 20 \quad 20 \quad 12$

Size of Bottles ......1/4 pt. 1/2 pt. Pt. Qt. Case $\ldots \ldots \ldots \ldots \ldots \ldots 0.85 \quad \$ 0.85 \quad \$ 0.75 \quad \$ 0.75$

Case with B. C. I. (bottom corner irons) $\ldots . .95 \quad .95 \quad .85 \quad .85$

Banded Case ........ $1.25 \quad 1.25 \quad 1.00 \quad 1.00$

Banded Case with B.

C. I. $\ldots \ldots \ldots \ldots \ldots$. $1.25 \quad 1.25 \quad 1.15 \quad 1.15$

Place Your Order With SATTERTHWAITE'S Dairy Supplies. 16 North Warren Street, Trenton, N. J. 


\section{POULTRY SUPPLIES.}

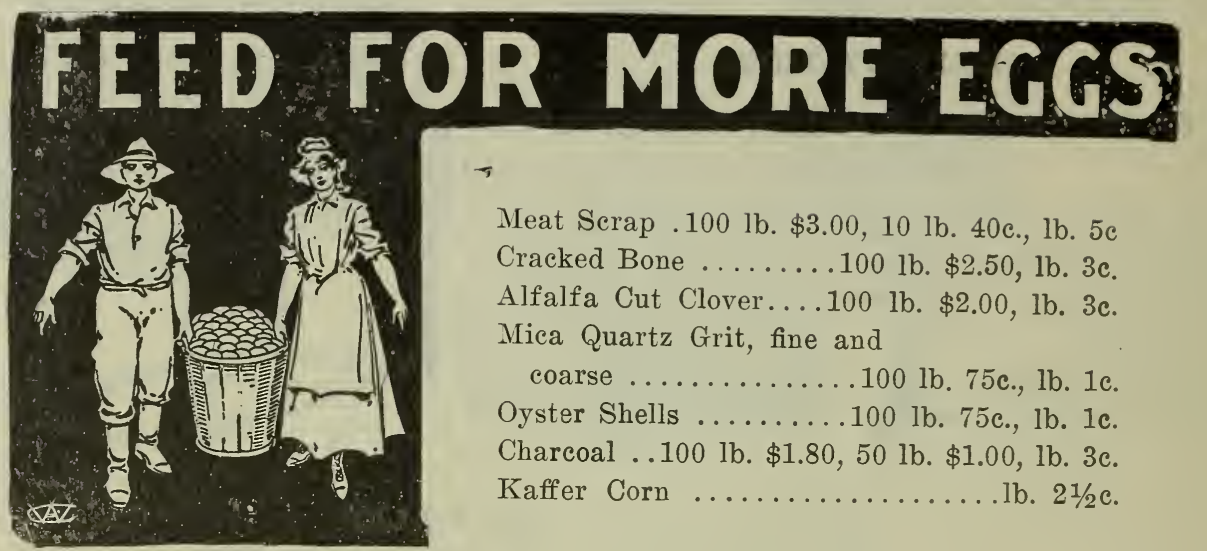

Conkey's Laying Tonic...25e. and 50c. pkg. Conkey's Roup Cure ........25 and 50c. Conkey's Cholera Remedy....25c. and 50c. Conkey's Bronchitis Remedy.........50c. Conkey's Poultry Tonic .....25c. and 50c.
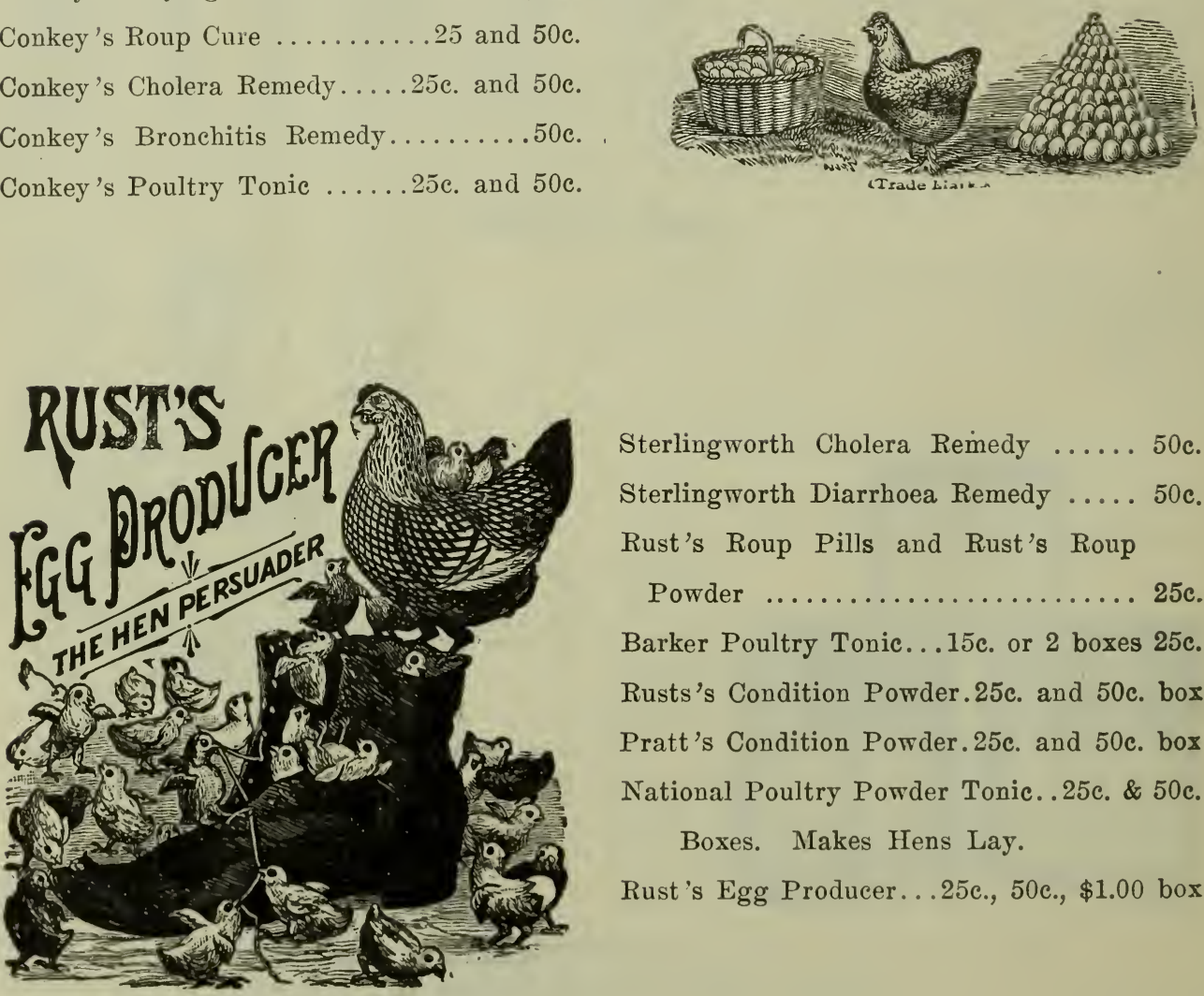

Sterlingworth Cholera Remedy .... 50 c. Sterlingworth Diarrhoea Remedy .....50c. Rust's Roup Pills and Rust's Roup Powder ................. 25c. Barker Poultry Tonic...15c. or 2 boxes 25c. Rusts's Condition Powder.25c. and 50c. box Pratt's Condition Powder.25c. and 50c. box National Poultry Powder Tonic..25c. \& 50c.

Boxes. Makes Hens Lay.

Rust's Egg Producer...25c., 50c., $\$ 1.00$ box 


\section{POULTRY SUPPLIES-Continued.}

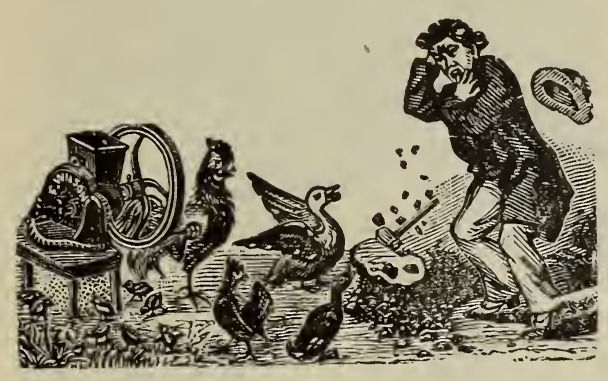

Buy a

SHELL AND DRY BONE MILL.

Price- $\$ 4.00$; with Stand, $\$ 5.00$.

It beats the hammer.

GREEN BONE MILL- $\$ 6.50$ up.

Call and Get Circular.

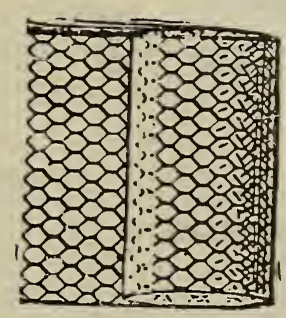

POULTRY WIRE.

New Jersey Wire Cloth the Best Woven.

2 in. mesh $\ldots \ldots \ldots \ldots 3 / 4$ ct. per sq. $\mathrm{ft}$. 1 in. mesh .........11 $\frac{12}{2}$ et. per sq. ft.

1 ft. Poultry wire, per roll...... \$0.72

11/2 ft. Poultry Wire, per roll....... 1.07

2 ft. Poultry Wire, per roll....... 1.42

$21 \% 2$ ft. Poultry Wire, per roll...... 1.80

3 ft. Poultry Wire, per roll....... 2.13

$3 \frac{1}{2} \mathrm{ft}$. Poultry Wire, per roll...... 2.50

4 ft. Poultry Wire, per roll....... 2.85

5 ft. Poultry Wire, per roll....... 3.53

6 ft. Poultry Wire, per roll....... 4.26

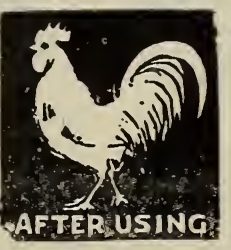

China Eggs .25 cts. dozen

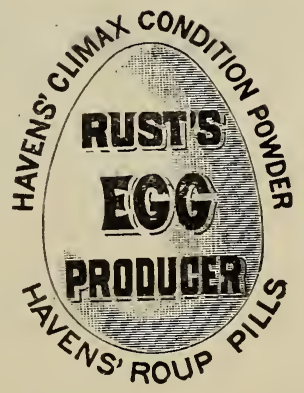

Rust's Egg Producer. See next page.

\section{BUY SATTERTHWAITE'S WARRENOID ROOFING}

WARRENOID ROOFING BEST MADE LASTS TEN YEARS. 


\section{POULTRY SUPPLIES-Continued.}

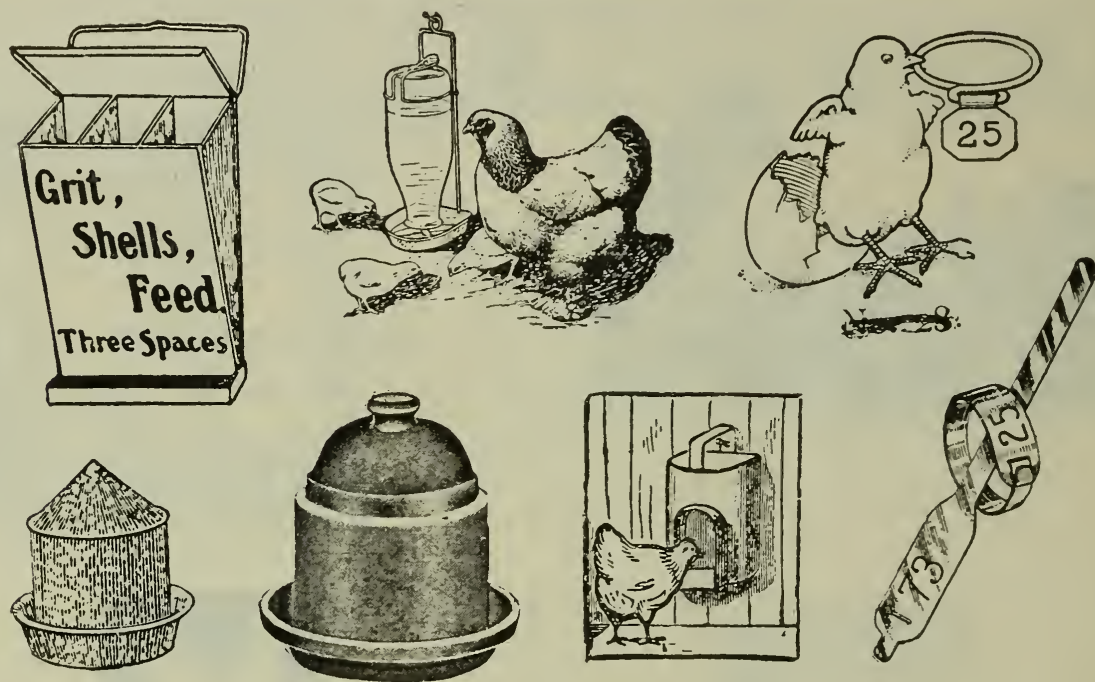

Grit Boxes, three spaces, small, 50 cts.; large, 75 cts.

Glass Chicken Wall Fountain or Feed Holder, complete, 25 cts.

Leg Bands, 12 ets. dozen; 75 cts. per 100.

GALVANIZED FOUNT-IT MAY BE HUNG AND IS CLEAN.

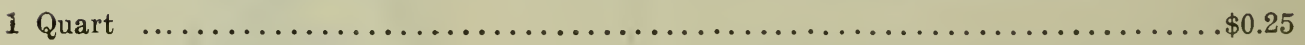

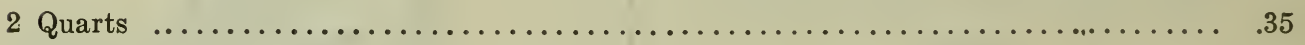

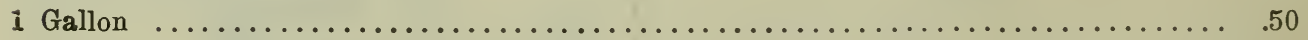

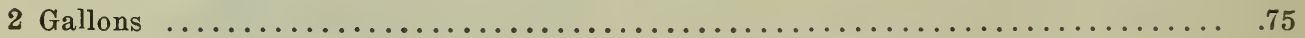

\section{NEW SANITARY FOUNT}

As in Cut.

Complete with Lamp and 1 gallon Fount $\ldots \ldots \ldots \ldots \ldots \ldots \ldots 1.65$

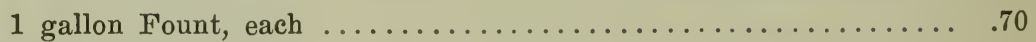

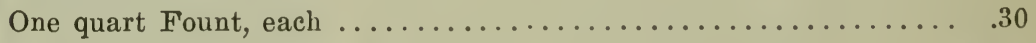

Complete with and 1 gallon Fount.................... $\$ 1.65$

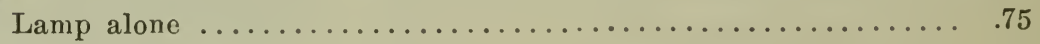




\section{POULTRY SUPPLIES-Continued.}

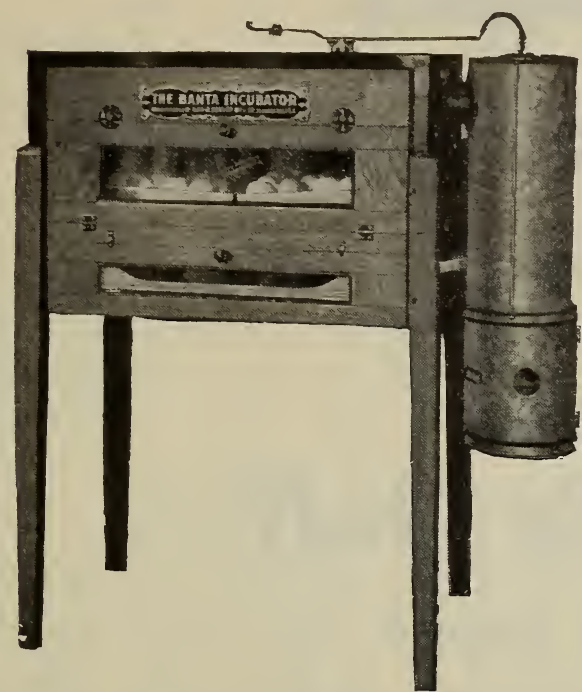

BANTA INCUBATOR.

Absolutely Fireproof-Metal Enclosed Lamp.

Sixteen years on the market. Perfectly safe and reliable at all times. Gold medal and diploma at the World's Fair, for machine in actual operation. Every machine is sold with the distinct understnding that it is perfect and is guaranteed in every respect.

Hot Air.

50 Egg size............... \$11.00

S0 Egg size................ 13.50

$120 \mathrm{Egg}$ size................. 18.50

240 Egg size............... 26.00

360 Egg size.............. 32.00

480 Egg size................ 44.00

720 Egg size............. 57.00

\section{OUTDOOR BROODERS.}

We have been selling these for sixteen years; nothing better has ever been offered at the price.

No. 6, 100 Chick, 34 in. wide, 50 in. long, 20 in. high, price $\$ 10.00$.

No. 7, 200 Chick, 34 in. wide, 72 in. long, 20 in. high, price $\$ 12.00$.

\section{COLONY BROODERS.}

Absolutely Fireproof-Iamp Enclosed in Metal Case.

This is one of the best Brooders we ever sold. See catalogue for full description. Large size, easily cleaned, guaranteed.

No. 8,48 in. long, 24 in. wide, 30 in. high, price $\$ 14.50$
No. 9, 60 in. long, 30 in. wide, 30 in. high, price $\$ 17.00$

No. 10, 72 in. long, 36 in. wide, 30 in. high, price $\$ 20.00$.

The best brooder on the market. Let us prove it to you.

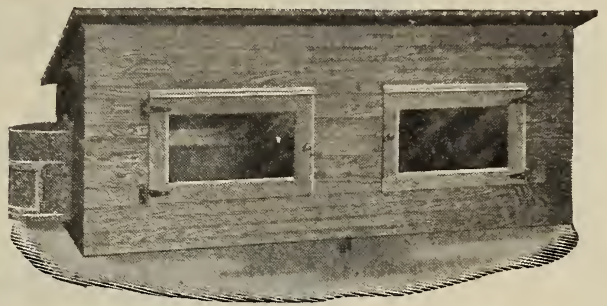

MANDY LEE INCUBATORS AND

BROODERS.

\begin{tabular}{|c|c|c|}
\hline Incubators-400-egg & $\begin{array}{l}\text { Wt., lbs. } \\
\text { size. . . } 260\end{array}$ & $\begin{array}{l}\text { Price. } \\
\$ 38.00\end{array}$ \\
\hline Incubators-280-egg & size...216 & 30.00 \\
\hline Incubators-200-egg & size. . . 192 & 25.00 \\
\hline Incubators-140-egg & size. . . 140 & 20.00 \\
\hline Incubators-100-egg & size. . . 133 & 16.00 \\
\hline Brooders-Fireless, N & o. $8 \ldots 45$ & 5.00 \\
\hline rooders-Fireless, N & ก. $10 \ldots 67$ & 8.0 \\
\hline
\end{tabular}

Ask to see our Pasteboard Brooder. Greatest ever for the money.

\section{INCUBATOR AND BROODER}

\section{SUPPIIES.}

Brooder Thermometer ..........\$0.50

Double Wafer for Regulator........ .75

Egg Tester .................. .25

Hygrometer (Mandy Lee) ........ 2.50

Lamp (Incubator) with Burner and Wick ......................90

Lamp (Brooder) with Burner and Wick ....................... .75

Lamp Wicks ( 2 for 5 cents), per doz. . $\quad .25$

Lamp Burner ................. .40

Thermometer (Incubator) for Mandy Lee ........................ .75

Thermometer (Incubator) with Legs; for any incubator ............ .60

See our supply catalogue for prices on other goods. 


\section{Sow \\ Satterthwaite's}

Evergreen Lawn Grass Seed

It Grows!

IT IS

\section{All Seed---No Chaff}

a quart weighs a pound

1 quart, 25c. 4 quarts, 85 c. 8 quarts, $\$ 1.50$. 1 bushel, $\$ 5.50$.

\section{SATTERTHWAITE'S}
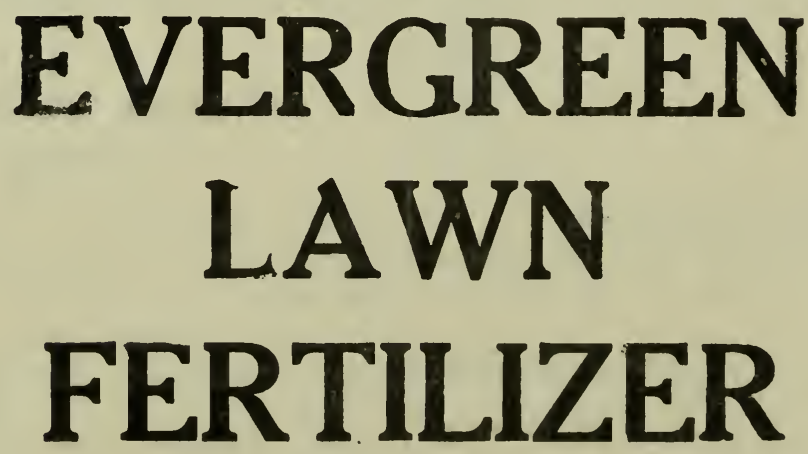

THE BEST LAWN FERTILIZER OBTAINABLE.
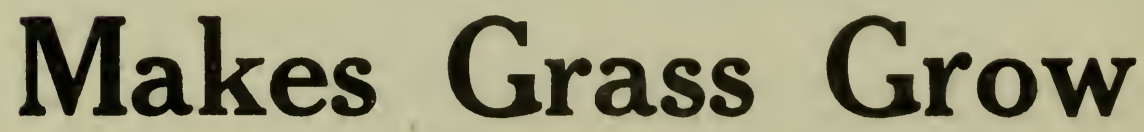

Per lb. 7 cts., Per 5 lb. pkg. 30 cts., 25 lb. pkg. $\$ 1.00$. 


\section{THE H. \& D. BROODER}

OF WATERPROOFED FIBRE BOARD.

(CONNOLLY PATENT OCT. 18, 1910 FEBRUARY 7TH.1911.

1. one of the most practical of poultry devices. A great deal of time has been spent in perfecting the brooder and is fully eppreciated by the up-to-date Poultry Man. ls the "Acme" of brooder construction.

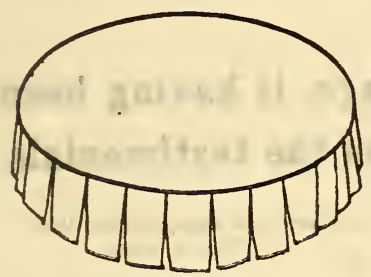

THE HOVER

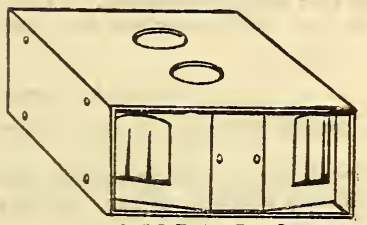

VENTILATION

The hover or blanket is of the tassel style, and made of a heavy woolen material. The hover is suspended from the roof of the brooder, allowing an air space of ample capacity between the top of the brooder and the top of the hover. This hover is also an inch and a half from all sides of the brooder walls, so as to allow the free circulation of air around the hover chamber, then out through the ventilation holes in the top of the brooder. This is the same as the principle of the old hen with her brooder, where you find the chickens with their heads through the feathers, breathing the fresh air.

The ventilation of the brooder can be varied at will by sliding the inner member backward or forward, closing the ventilating holes in the top of the brooder.

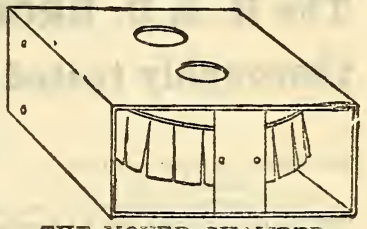

THE HOVER CHAIIBER One can easily tell, by placing the hand within the hover chamber, whether it is of the proper degree of heat. You will also know from the little chicks themselves as to whether they are comfortable or not, for the contented song of the little fellows is a sign that "all's well."

The chance of any drafts entering the hover chamber is eliminated by a disc, thus preventing cold air falling upon the backs of the chickens. The openings to the hover chamber are also hea vily curtained, thus helping to exclude drafts.

A great deal of attention has been paid to the ventilation of the brooder, and we believe that you will agree with us that it has been very well taken care of.

The walls of the brooder are so constructed that there are no corners in which the chickens might crowd and the weaker ones smother and be trampled upon. The Hexagonal construction of the walls is responsible for the absense of corners.

A litter of about two inches of chaff, cut alfalfa, clover, hay-seed, or the like, is placed in the bottom of the brooder, hullowed out in the center and built up on the sides.

The brooder is now ready for the day-old chicks, and for the first day they are confined within the brooder. On the second or third day the yard is extended a little so as to let the chicks begin to find their way out of the hover chamber into the exercising yard.

Should the chicks begin crowding within the brooder they either crowd themselves out into the exercise yards or into the centre of the hover chamber.

You will note from the cuts that THE H. \& D. BROODER has two yards, one on either side, and for the first five or sixdays but one yard is used, the openings to yard No. 2 being

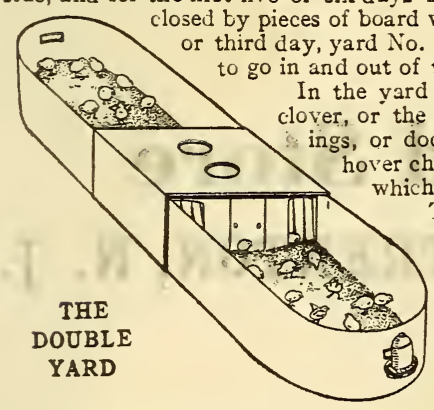
closed by pieces of board which are supplied with the brooder. Aiter the second

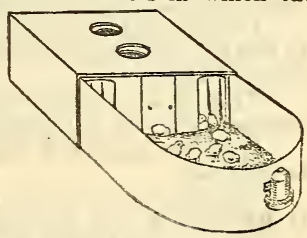

DRAUGETS=-Preveatativo In this way it keeps the little fellows working all the time, getting the proper exercise, and does away with the crowding of all the chicks into the one yard. When the chicks are about three or four weeks old, the yards can be done away with, and they can then bave the free run of the space which has been prepared for them. Water is placed outside the walls of the yards, and opening being made in each yard for the chicks to get

After the chicks are five or six days old, yard No. 2 can be extended about six inches, and after they are eight or ten days old, both yards can be brought to their full length, which will give a very large exercising yard, and bring them in and out through the hover chamber to get to the yards.

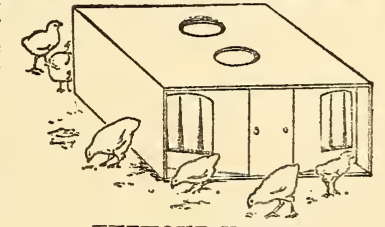

WITHOUT YARDS 


\section{The H. \& D. BROODER is past the experimental age, it having been thoroughly tested and proven satisfactory, as from the testimonials.}

The Hinte \& Dauch Paper Co., Sandusky, O.

GeNTLEMEN:-Replying to your favor of recent date $I$ wish to say that the two brooders which I purchased from you last June gave me excellent results. I placed fifty chickens in each of the brooders and lost but two out of the hundred. The chickens were at all times smart and active, and seemed to do better in your brooders than in any of the heated brooders that I have ever used.

Trapelo Road. Sinccrely yours, F. W. REED.
362 Eastern Avenue, Malden, Mass.,

The Himps \& Dauch PAFBR Co.

Dec. 8, 1910.

\section{Boston, Mass.}

GBNTLBueN:-Your brooder gave perfect satisfaction. I put in thirty-five chicks and only lost four. Will use several more next season.

The brooder is built in but one size, of fifty chick capacity, as we find that it is the general tendency of the poultry man to place but this number in brooders, better results being obtained.

The brooder will take care of the chicks up to six weeks of age, at which time they are ready for the colony houses. One of these brooders may be placed in the colony house, so that it will do away with the unnecessary handling of the chickens saving a great deal of time and labor.

In almost every Poultry Journal, one reads of the essential need of cleanliness with poultry, and this greatest of need can be secured by the adoption of THE H. \& D. BROODER.

Owing to the low cost of the brooder they can well afford to be thrown away after the brooding of each lot of chicks. In this way the up-to-date poultry man has his poultry free from vermin and diseases, as a fresh brooder is supplied for each lot of chickens.

THE H. \& D. BROODER can be used either indoors o- out of doors. When used out of doors it is to be placed in a weather tight box, protecting it from the rain and snow.

A certain amount of common sense should be used in operating THE H. \& D. BROODER, when excellent results will be obtained.

From the above detailed description of the brooder, and from the cuts you will agree that by the use of THE H. \& D. BROODER your brooder troubles will be ended.

The price of THE H. \& D. BROODER IS $\$ 2.00$ at store.

\section{TOR QALE BY}

\section{Satterthwaite Seed Store}

\section{POULTRY SUPPLIES.}




\section{REFERENCE TABLES.}

Quantity and Seed Requisite to Produce a Given Number of Plants to Sow an Acre.

(QUANTITY

PER ACRE

Artichoke, 1 oz. to son p'ants.... 6 o oz. Asparagus, 1 oz. to s(i) plants.... 1 lb. Barley .................... Beans, dwart, $1^{1} \geq$ pints to 100 feet o drill .............

Beans, pole, $1^{1}$.2 pints to 100 hills. 1/2 bus. Beet, garden, 1 oz. to 100 feet of lri!l ..............

Beet. Nangel, 1 oz. to 100 feet of drill

Broccoli, 1 oz. to 3,000 plants ....

Broom Corn ...............

Brussels Sprouts, 1 oz. to $3,0,00$ plants ..............

Buckwheat .............. 1/4 bus. ('abbage, 1 oz. to 3,000 plants .... 4 oz. Carrot, 1/4 oz. to 100 feet of drill. . 21․․ $1 \mathrm{bs}$. ('auliflower, 1 oz. to 3,000 plants. . $4^{-}$oz. ('elery, $1 \mathrm{oz}$. to 15,000 plants..... 4 oz. Clover, Alsike and White Dutch...6 6 lbs. " Lucerne Large Red; Crimson Trefoil .......... 8

، Medium ........... 12 lbs Collards, 1 oz. to 3,000 plants.... 4 oz Corn, sweet, $1 / \pm$ pint to $100 \mathrm{hi} \mathrm{ls}_{\mathrm{s}} . .5 \mathrm{5}$ ats. Cress, 1/2 oz. to 100 feet of drill...10 lbs. Cucumber, 1 oz. to 100 hills ..... 3 lbs. Eggplant, 1 oz. to 2,000 p'ants.... 4 oz Endive. $1 / 4$ oz. to 100 feet of drill. $4 \frac{1}{2}$ lbs Flax, Broadeast ........... $1 / 2$ bus. Garlic, bulbs, 1 lb. to $10 \mathrm{ft}$. of drill.

Gourd, 2 ozs. to 100 hills ........

Grass, Blue, Kentucky ........2 2 bus. "6 Blue, English ........... 1 bus " Hungarian and Nillet..... 1/2 bus. ، Mixed Lam ......... 3 to 5 bus. " Orchard, Perennial Rye, Red Top, Fowl Meadow and Wood Meadow .......... 2 bus. “ Rell Top, Fancy Clean. .8 to 10
Grass, Timothy

Hemp ...............

Kale, 1 o\%. to 3,000 p'ants ..... 4 oz.

Kohlrabi, 1-3 oz. to $100 \mathrm{ft}$. of drill. 4 llss.

Leek, 1-3 oz. to 100 feet of drill... 4 llos.

Lettuce. 1/1 oz. to 100 feet of drill. 3 lbs.

Martynia, 1/2 oz. to $100 \mathrm{ft}$. of drill. $5 \mathrm{lbs}$.

Melon, Musk, 1 oz. to 100 hills... . 3 lbs. " Water, 4 oz. to 100 hills... 3 lbs.

Nasturtium, 2 oz. to 100 feet of drill ................

Oats ............... 2 bus.

Okra, $1^{1}$. oz. to 100 feet of drill. $\bar{s}$ lbs.

Onion Seed, $1-3 \mathrm{oz}$. to 100 feet of drill ..................... to 5

Onion Seed for Sets .......40 to 80

Onion Sets, 1 qt. to $20 \mathrm{ft}$. of drill. S

Parsnip, $1 / 4$ oz. to 100 feet of drill. 3 lbs.

Parsley, $1 / 4$ oz. to 100 feet of drill. 3 libs.

Peas, garlen, 1 pint to 100 feet of drill

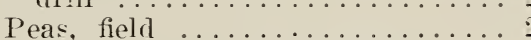

Pepper, 1 oz. to 1,500 plants. . . . .

Potatoes ............. s bus.

Pumpkin, 1-3 quart to 100 hills.3 to $t$ lhs.

Radish, 2-3 oz. to $100 \mathrm{ft}$. of drill.

10 to $12 \mathrm{lbs}$.

Rye ................. 11 bus.

Sa!sify, 1.2 oz. to $100 \mathrm{ft}$. of drill... S lis.

Spinach, $1 / 2$ oz. to $100 \mathrm{ft}$. of drill.. s lbs.

Summer Savory, 1 packet to 100

feet of drill ............ $3 / 4$ lbs. Squash, Summer, 4 ozs, to 100 hills. 3 lbs. Winter, 8 ozs. to 100 hills. 3 lbs.

Tomato, $1 \mathrm{oz}$. to 2500 plants .... 2 oz. Tobacco, 1 oz. to 5,000 plants..... 2 oz. Turnip, 1 oz. to 250 feet of drill... 11/2 lbs. Vetches ............... 2 bus. Wheat ................ 11/4 hus.

\section{Number of Plants or Trees to the Acre at Given Distances.}

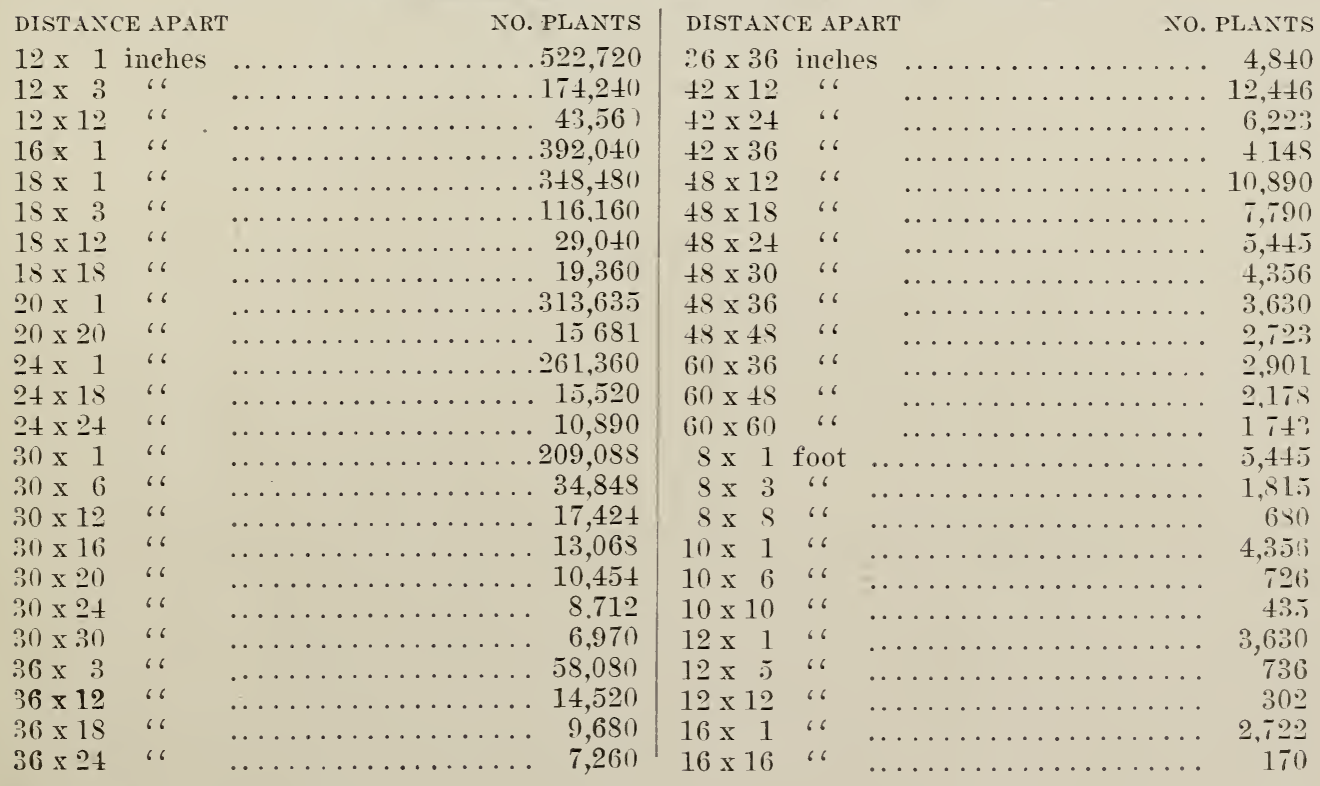




\section{Satiterthwalite's}

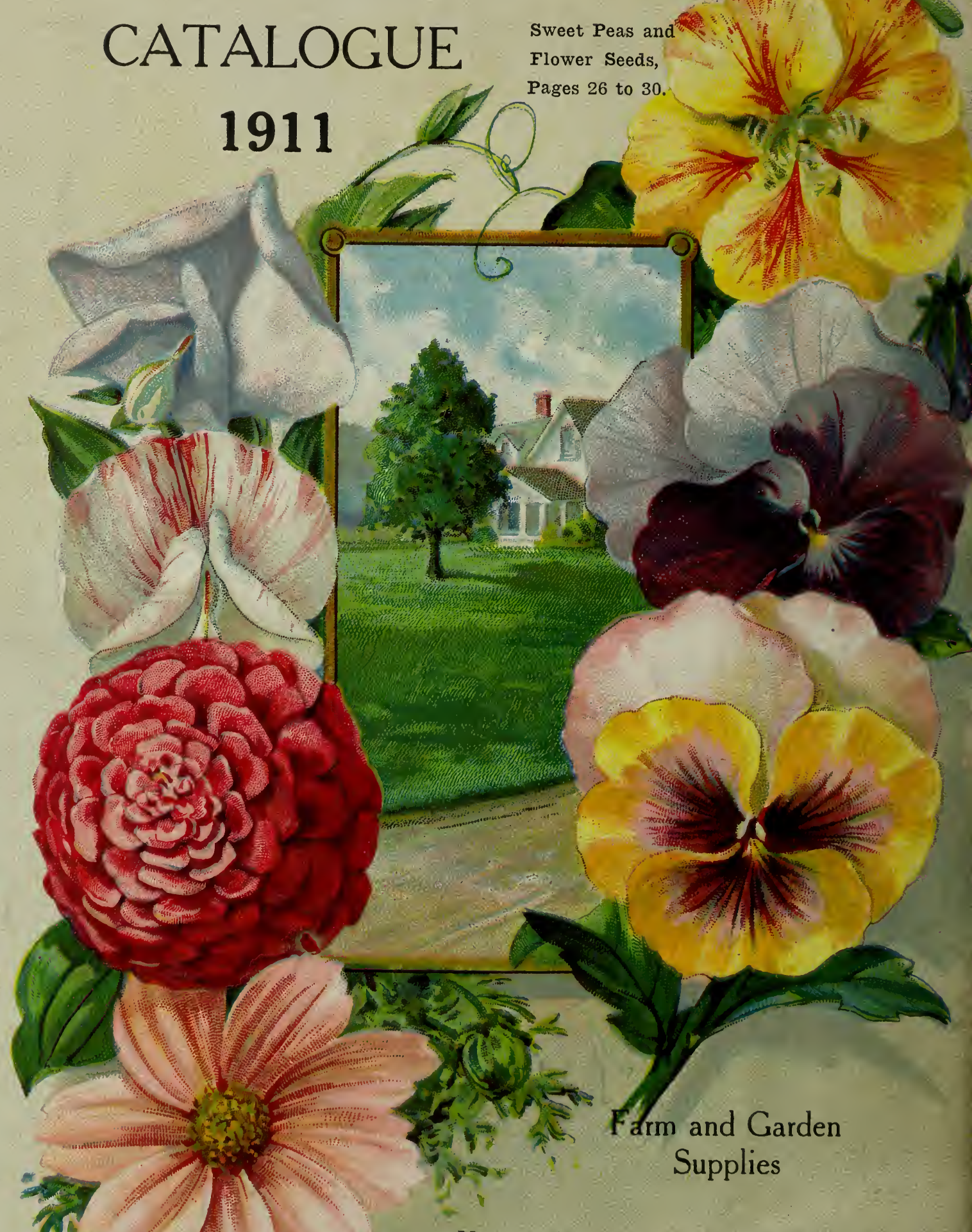

No. 16 N. Warren St., Trenton, N. J.

Bell Phone 822-A, Inter-State 1042-B

Opposite Trent Theatre

NEAR ALL SUBURBAN TROLLEY TERMINALS 